\title{
Morphology, typification and critical analysis of some ecologically important small naviculoid species (Bacillariophyta)
}

\author{
Carlos E. Wetzel ${ }^{1 *}$, Luc Ector ${ }^{1}$, Bart VAn De ViJver ${ }^{2,3}$, Pierre Compère ${ }^{2} \&$ David \\ G. MANN ${ }^{4,5}$
}
${ }^{1}$ Luxembourg Institute of Science and Technology, Department Environmental Research and Innovation (ERIN), 41 rue du Brill, L-4422 Belvaux, Luxembourg; ${ }^{*}$ Corresponding author e-mail: carlos.wetzel@list.lu ${ }^{2}$ Botanic Garden, Meise, Department of Bryophyta \& Thallophyta, Nieuwelaan 38, B-1860 Meise, Belgium
${ }^{3}$ University of Antwerp, Department of Biology, ECOBE, Universiteitsplein 1, B-2610 Wilrijk, Belgium
${ }^{4}$ Royal Botanic Garden Edinburgh, Edinburgh, EH3 5LR, Scotland, UK
${ }^{5}$ Aquatic Ecosystems, Institute for Food and Agricultural Research and Technology (IRTA), Crta de Poble Nou Km 5.5, E-43540 Sant Carles de la Ràpita, Catalunya, Spain

\begin{abstract}
The identity and nomenclatural history of several small-celled naviculoid taxa are revisited. The species discussed here are important from the ecological point of view since they are often dominant in benthic freshwater communities. The original concepts of several species that have suffered major taxonomic drift due to their entangled nomenclatural history are discussed, and forgotten epithets are resurrected. We examined the original material of Navicula aggerica E. ReIchardt, Navicula atomoides Grunow, N. crassulexigua E. Reichardt, $N$. minima Grunow, $N$. minima var. typica R. Ross, $N$. minutissima (Kütz.) Grunow, N. saugerresii Desm., N. seminulum Grunow, N. seminulum var. intermedia Hust., N. seminulum var. radiosa Hust., N. stroemii Hust., N. subbacillum Hust., N. subseminulum Hust., N. tantula Hust., N. vasta Hust., N. ventraloides Hust., Stauroneis fonticola Hust., and Synedra minutissima KüTz. Several of these names were regarded as synonyms in many floristic works and, as such, remained forgotten or ignored. Analyses using light and scanning electron microscopy indicate conspecificity of Navicula minima (= Sellaphora seminulum sensu auct. nonnull.) with Sellaphora saugerresii (DESM.) C.E. Wetzel et D.G. MANN comb. nov., which has priority against $N$. minima. Synedra minutissima is lectotypified and transferred to Halamphora minutissima (Kütz.) C.E. Wetzel et COMPĖre comb. nov. Navicula minutissima (KüTz.) Grunow 1860, nom. illeg. and Navicula minima Grunow pro parte, typo excl. designate one and the same species (valid and legitimate), currently known as Sellaphora aggerica (E. Reichardt) FAlASco et Ector. We consider Sellaphora atomoides (Grunow) C.E. Wetzel et Van DE ViJver comb. nov. (= Eolimna tantula sensu auct. nonnull.) and Sellaphora nigri (De Not.) C.E. Wetzel et ECTOR comb. nov. (= Eolimna minima sensu auct. nonnull.) to be separate species, although morphologically very similar. Sellaphora crassulexigua (E. Reichardt) C.E. Wetzel et Ector comb. nov. and Sellaphora subseminulum (Hust.) C.E. Wetzel comb. nov. are rarely encountered, but usually found in calcareous springs and aerial habitats, respectively. All species are transferred to the genus Sellaphora on the basis of their valve morphology, pending molecular studies confirming the monophyly of the group once living material of each can be located and brought into clonal culture. Additionally, 64 established taxa from Navicula s.1., Eolimna or Naviculadicta are formally transferred to Sellaphora. Navicula subminuscula MANGUIN is formally transferred to the genus Craticula Grunow.
\end{abstract}

Key words: Diatoms, Navicula, Sellaphora, Eolimna, Naviculadicta, morphology, taxonomy, type material, Grunow, Hustedt, Kützing, Rabenhorst, Van Heurck

\section{INTRODUCTION}

Small naviculoid diatoms currently assigned to the genera Sellaphora MereschK. or Eolimna Lange-Bert. et W. SchilLer are very important from the ecological point of view since they are often among the most abundant benthic species in freshwater systems. Most of them can hardly be identified using light microscopy (LM) and for many complexes the lack of scanning electron microscopical (SEM) illustrations is a major impediment. Moreover, there is considerable uncertainty about their identities, due in part to the lack of publications with good illustrations of type material (or original material) but also to the changes in taxonomic 
concept that some species have suffered over time.

Efforts to elucidate taxonomy based on type material are not new in diatom research. Some recent examples concerning freshwater environments and 'old' established species complexes have focused on the genera Achnanthidium KüTz. (VAN DE VIJVER et al. 2011; TAYlor et al. 2014), Amphora EhrenB. ex KütZ. (LeVkov 2009), Cocconeis Ehrenb. (Romero \& JAHN 2013; Riaux-Gobin et al. 2014), Encyonema Kütz. (Silva et al. 2013), Eunotia Ehrenb. (LANGe-BertaLOT et al. 2011), Fragilaria LyngB. (Tuj \& Williams 2013; Lange-Bertalot \& Ulrich 2014), Gomphonema Ehrenb. (Reichardt 2015a, b), Luticola D.G. Mann (Levkov et al. 2013), Nitzschia Hassall (Trobajo et al. 2013) and small naviculoid species (WeTzel et al. 2013). Furthermore, cryptic diversity seems to be very common in diatoms (MANN \& VANORMELINGEN 2013, AbArCA et al. 2014, Rimet et al. 2014), increasing the difficulty of developing a stable taxonomy. However, well-defined morphological circumscriptions are essential as a first step in taxonomic revision, to avoid the precipitate description of doubtful taxa and synonyms (see Novis et al. 2012).

The small naviculoid species that we deal with here were previously studied by Hustedt (1962) and also by PATRICK \& REIMER (1975), who provided drawings based on original material. GRANETTI (1968d), Lange-Bertalot \& Bonik (1976), Schoeman et al. (1976), Schoeman \& ArchiBAld (1977), LANGE-BertaLOT \& Rumrich (1981), Weber \& McFarland (1981), Krammer \& LANGE-Bertalot (1986) and more recently PotAPOVA (2013) have provided micrographs taken with light and electron microscope techniques. Poor circumscriptions and sometimes a lack of reliable information surround the epithets 'minima', 'minutissi$m a$ ' and 'seminulum', even though they are apparently well-established and often referred to in the ecological and taxonomic literature. Thus, for example, a non-exhaustive search for SEM images of this group in the literature shows a high diversity of forms, to which a wide variety of names have been applied (e.g. KoBAYASI \& MaYAma 1989; Coste \& RicARD 1990; Lobo \& Kobayasi 1990; Maier \& Rott 1990; Schmidt et al. 1990; Wasell \& HÅkansson 1992; Karayeva \& GenKAL 1993; Rott 1995; Silva-Benavides 1996; KuliKovSKIY et al. 2010a, b; Siver \& HAMILTON 2011; ŻELEZNAWIECZOREK 2011). In this contribution we lectotypify some well-known and widely distributed species, propose new combinations, and resurrect some forgotten epithets usually considered as synonyms.

\section{Material And Methods}

Type slides and unmounted type material were examined using LM and SEM. Original material from the VAN HeURCK collection [Botanic Garden Meise (BR), Belgium], Grunow collection [Naturhistorisches Museum Wien (W), Vienna,
Austria], Hustedt collection [Alfred-Wegener-Institut für Polar- und Meeresforschung (BRM) Bremerhaven, Germany], Natural History Museum [(BM), London, UK] and the personal collection of Erwin ReIchARDT (no acronym, Treuchtlingen, Germany) was used. Herbarium acronyms follow THIERS et al. [CONTINUOUSLY UPDATED]. Several samples collected in Luxembourg in the context of Water Framework Directive monitoring were analysed and one of them was used for the illustration and neotypification of Navicula nigri DE Nот. The term "original material" is used here according to the International Code of Nomenclature for algae, fungi, and plants (ICN, McNeILl et al. 2012). The symbols " $\equiv$ " and "=" before the names of specific and infraspecific taxa are used to represent homotypic or nomenclatural, and heterotypic or taxonomical synonyms, respectively. A third type of synonym which can be called a concept synonym is marked by "-". This concerns invalid names, misapplied names and taxonomic synonyms which do not include the type of the name, following JAHN \& KUSBER (2009).

The following materials were observed in LM and/or SEM. Their provenances and treatment are as follows (in alphabetical order):

Navicula aggerica E. ReICHARDT 1982: Raw material from the Steinerne Rinne, near Weisenburg, Bavaria, Germany. Unmounted material from sample S61-T01 (E. REICHARDT personal collection) was prepared for SEM.

Navicula atomoides Grunow in VAN HeURCK 1880: The original slide from VAN HeURCK collection Type ${ }^{\circ} 219$ (from the set of VAn Heurck's "Types du Synopsis des Diatomées de Belgique" at the Botanic Garden Meise (BR) was observed. No raw material is available for this slide, which was collected from a 3-year culture from an aquarium at Antwerp (Belgium). Instead, SEM images of Navicula atomoides were taken from raw material of sample "Type $n^{\circ} 143$ " ['Eaux douces - Bruxelles (Delogne)'], where the species was also abundant.

Navicula crassulexigua E. REICHARDT 1994: Raw sample $\mathrm{n}^{\circ}$ S668-T01 from Steinerne Rinne, near Erasbach (Oberpfalz), Bavaria, Germany. Unmounted material from E. REICHARDT personal collection was prepared for SEM and a new slide was prepared for LM observations. Two populations from calcareous sources in France (Scie River at Saint-Macloude-Folleville, Normandy) and from Italy (Bossea cave, SW Alps) were also observed.

Navicula minima Grunow in VAN Heurck 1880: Raw sample from a freshwater bottle ['Eaux douces, Bruxelles, dans une carafe (Del.)'] Van HeurCK collection sample "Type $n^{\circ}$ 142 " housed in the Botanic Garden Meise (BR). Unmounted material was prepared for SEM and a new slide prepared in Naphrax.

Navicula minima var. typica R. Ross 1947, nom. inval.: Several slides from the Canadian Eastern Arctic mounted and published by Ross (1947) and housed in the Natural History Museum, London (BM 35933, BM 35934, BM 35935, BM 35957 and BM 35958) were examined. Images corresponding to 'Navicula minima var. atomoides' sensu Ross (1947) and his new variety "typica" were also taken from the slide BM 35933 (Lake Harbour, Baffin Island, Canada).

Navicula minutissima (KüTz.) Grunow 1860: Two samples of raw material from Pöllan, Carinthia (Austria), deposited at the Naturhistorisches Museum, Vienna (W) (Grunow Collection, $n^{\circ} 74$ : acquisition 1901/3072, Fig. 1; acquisition 1901/3073, Fig. 2) were examined. Both were labelled as Navicula minutissima Grun. and cleaned material had been 
dried onto small pieces of glass. Small amounts of this were scraped off into deionized water and prepared for LM and SEM analysis.

Navicula nigri DE Noт. 1872: The original material used by De NotaRis ['Erbario Crittogamico Italiano' (1858-1885)], was illustrated using transmission electron microscopy (TEM) by GRANETTI (1968d). The provenance of the original material observed by De Notaris \& Baglietto (1872) was the Po River at Casale Monferrato (Piedmont region, province of Alessandria, Italy) collected by NEGRI in 1871 . Here we used a recent freshwater benthic sample collected from the Troine River (Tretterbaach), Léresmillen, Luxembourg, leg. $23 / 08 / 2011$, to illustrate a population identified by us as Navicula nigri. The neotype designated here is deposited at the Botanic Garden Meise (BR) under the number BR-4396. An additional population fitting into the concept of Navicula nigri but containing smaller specimens was observed as well. The population was collected in the Veyle River, a left tributary of the Saône River at Vonnas (Rhône-Alpes Region) in the Ain department, France.

Navicula saugerresii DESM. 1858: Raw material from France deposited at the Naturhistorisches Museum, Vienna (W) in the Grunow collection (acquisition 2009, $\mathrm{n}^{\circ}$ 801). Material corresponding to "Navicula saugerri DESM.", n 506. A small amount of the original unmounted material (Fig. 3) was removed and was prepared for LM and SEM.

Navicula seminulum Grunow 1860: Two samples loaned from different collections were analysed. For both samples unmounted raw material was prepared for LM and SEM analysis: 1) raw material from "Radegund", Liechtenstein. (Fig. 4) housed in the Naturhistorisches Museum (W), Vienna (GRuNow collection, $\mathrm{n}^{\circ} 1580$, acquisition 1901, $\mathrm{n}^{\circ} 3079$. "Navicula minutissima Grun."); 2) the sample "Type n ${ }^{\circ} 143$ " ['Eaux douces - Bruxelles (DELOGNE)'] from the VAN HeURCK collection housed in the Botanic Garden Meise (BR). Both materials were used for SEM and LM analysis.

Navicula seminulum var. intermedia Hust. 1942: Sample E3808 from a source ('Boreochlus-Quelle') in Abisko, Lappland (Sweden), deposited in the Hustedt collection [BRM, Bremerhaven, Germany]. Oxidized (treated) material corresponding to the type slide N7/66 was prepared for SEM. Navicula seminulum var. radiosa Hust. 1954: Sample E5926 from mud ('Grundschlamm') collected from Immerather Maar, Eifel, Rheinland-Pfalz (Germany) and housed in the HustedT collection [BRM, Bremerhaven, Germany]. Oxidized (treated) material corresponding to the type slide W4/98 was prepared for SEM. A new slide was prepared for LM observations.

Navicula stroemii Hust. 1931: Sample E2514 from Feforvatn, Oppland Co., Norway, housed in the HustedT collection [BRM, Bremerhaven, Germany]. Oxidized (treated) material corresponding to the slide 191/3 was prepared for SEM and a new slide was prepared in Naphrax.

Navicula subbacillum Hust. 1937: Sample AS726 from Singkarak, Sumatra, Indonesia, housed in the HustedT collection [BRM, Bremerhaven, Germany]. Oxidized (treated) material corresponding to the slide $\mathrm{N} 12 / 22$ was prepared for SEM.

Navicula subseminulum Hust. in BRENDEMÜHL 1949: Observations were made on slide N12/80 in the HUSTEDT collection [BRM, Bremerhaven, Germany], from an aerial sample collected in 'Wenzen bei Göttingen' (Germany) at the edge of a beech (Fagus) forest. No material was available for SEM investigation.

Navicula tantula Hust. 1937: Sample E869 collected from bryophytic material (Hypnum Hedw. spp.) from Poggenpohls Moor, Niedersachsen (Germany), and deposited in the HustedT collection [BRM, Bremerhaven, Germany]. Oxidized (treated) material corresponding to the slide N8/44 was prepared for SEM and a new slide was prepared for LM observations.

Navicula vasta Hust. 1937: Sample AS325 from TenggerMassiv, Java, Indonesia housed in the HustedT collection [BRM, Bremerhaven, Germany]. Oxidized (treated) material corresponding to the slide N8/90 was prepared for SEM.

Navicula ventraloides Hust. 1945: Sample E761 from 'Plitvicer Seen', Croatia housed in the HusTEDT collection [BRM, Bremerhaven, Germany]. Oxidized (treated) material corresponding to the slide M2/43 was prepared for SEM.

Stauroneis fonticola Hust. 1934: Sample AS321 from a green floc collected at $10 \mathrm{~cm}$ depth in a spring in the Tengger Mountains ('Tengger-Massiv'), Java, Indonesia housed in the HustedT collection [BRM, Bremerhaven, Germany]. Oxidized (treated) material corresponding to the slide Na1/38 was prepared for SEM and a new slide was prepared for LM observations.

Synedra minutissima Kütz. 1844: Raw material from the original gathering ("Francolino am Po Ufer", Italy) deposited in the Natural History Museum [(BM), London, UK], was scraped from a broken slip cover and prepared for SEM. The type slide BM 18149, corresponding to the preparation "KüTZING prep. 199" (Fig. 5), was observed as well.

Subsamples from all raw and already oxidized materials were cleaned (digested) using concentrated $\mathrm{H}_{2} \mathrm{O}_{2}$, heating for 24-48 $\mathrm{h}$ using a sand bath. Preparations were then allowed to cool and settle for $24 \mathrm{~h}$, and 80 to $90 \%$ of the supernatant was eliminated by vacuum aspiration. A volume of $1 \mathrm{ml}$ of $\mathrm{HCl}(37 \%)$ was then added and the mixture was allowed to stand for $2 \mathrm{~h}$, followed by three repetitions of rinsing and decantation as described above, using deionized water. Following digestion and decantation, cleaned material was rinsed and diluted with deionized water and mounted permanently on glass slides using Naphrax ${ }^{\circledR}$ as mounting medium (Brunel Microscopes Ltd., Chippenham, Wiltshire, UK) for qualitative analysis. Light microscopy (LM) observations, identifications, measurements and micrographs were performed with a Leica ${ }^{\circledR}$ DMR microscope equipped with a LeicaDFC 500 high-resolution digital camera using Leica Application Suite software (v. 4.4.0, Leica Microsystems ${ }^{\odot}$ ). Images were taken using brightfield contrast. For SEM, parts of the oxidized suspensions were filtered and rinsed with additional deionized water through a $3-\mu \mathrm{m}$ Isopore ${ }^{\mathrm{TM}}$ polycarbonate membrane filter (Merck Millipore). Filters were mounted on aluminium stubs and coated with platinum using a BAL-TEC MED 020 Modular High Vacuum Coating System for $30 \mathrm{~s}$ at $100 \mathrm{~mA}$. A Hitachi SU-70 ultra-high-resolution analytical field emission (FE) scanning electron microscope (Hitachi High-Technologies Corporation, Tokyo, Japan), operated at $5 \mathrm{kV}$ and with a $10 \mathrm{~mm}$ working distance, was used for the analysis. SEM images were taken using the upper and lower (SE-U, SE-L) detector signals. Photomicrographs were digitally manipulated and plates containing light and scanning electron micrographs were created using CorelDraw $X 6^{\circledR}$. Hotelling's multivariate discriminant analysis (Hotelling 1951) was performed to test morphometric differences (length, width, and length/width ratio) between $N$. atomoides and $N$. nigri populations using PAST software, version 2.17 (HAMmER et al. 2001). Additional graphics were constructed using R (R Core Development Team 2014). 


\section{Results ANd Discussion}

\section{Lectotypification of Synedra minutissima KüTZ. 1844}

Die kieselschaligen Bacillarien oder Diatomeen, p. 63, pl. 3, fig. 30.

KüTZING (1844) described "Synedra? minutissima" as occurring "Unter einer Oscillaria bei Francolino am Po-ufer an der Strasse nach Ferrara 1835". According to KüTZING l.c. this small species is around $11 \mu \mathrm{m}$ in length (KüTZING gave measurements as fractions of the Paris line or ligne, which is $2.256 \mathrm{~mm}$ : his measurement of 'Länge $1 / 200^{\prime \prime \prime}$ ' therefore equates to $1 / 200$ $\times 2256 \mu \mathrm{m}=11.28 \mu \mathrm{m}$ ), cells narrow linear in girdle view (latere primario angustissime linearis) and obtuse-lanceolate in valve view [(latere) secundario lanceolata obtusiuscula] (Fig. 6). His drawings show eight small linear-lanceolate cells, not forming colonies, somewhat rectangular in girdle view and with a rather irregular outline (Fig. 7). Two cells located on the right hand side of his drawing shows a longitudinal eccentric line. No striae or fibulae were illustrated and the species is rather hyaline, without precise details. The drawings presented are amongst the smallest specimens on KüTZING (1844) plates.

Our LM observations from type slide BM 18149 of KüTZING's original material collected in Italy, showed a relatively species-rich sample (Table 1) with a dominance of two small naviculoid species currently assigned to the genus Mayamaea LANGE-BERT., the dominant species being Mayamaea atomus (KüTZ.) LANGe-Bert. (Figs 8-15), which accounted for 38\% of all diatoms. Mayamaea permitis (HUST.) BRUDER ET MedLin was less abundant, comprising $29 \%$ of the total. Most probably KüTZING was unable to differentiate these two species. Mayamaea atomus was described and illustrated in detail by KüTZING in the same work as Amphora atomus KüTz. (1844, p. 108, pl. 30, fig. 70).

Two other common species found on the slide are also illustrated here: Nitzschia frustulum (KüтZ.) Grunow (Figs 16-20) and Navicula wiesneri LANGEBERT. [Figs 21-24 (= Navicula heufleri f. minuta GrunOw)], with $8.4 \%$ and $6.0 \%$ relative abundance respectively. Although both species have lanceolate outlines like that illustrated by KüTZING for $S$. minutissima, $N$. frustulum possesses conspicuous fibulae in LM while $N$. wiesneri has clearly visible striae. Neither character is present in KüTZING's drawings. Moreover, both of these species are larger than the dimensions given in the protologue of S. minutissima.

A few years after KüTZING described Synedra minutissima, RABENHORST (1853, p. 39, pl. 6, fig. 80) described Navicula minutissima RABenH. from 'Südpersien' (Iran). However, for RABENHORST, S. minutissima KüTZ. and $N$. minutissima were different entities. Indeed, he identified and illustrated Synedra minutissima (RABEnHorst 1853, pl. 4, fig. 33) among the other araphid species he recognized. In his list of synonyms, RABENHORST 1.c. (p. 72) placed Frustulia pelliculosa BRÉB. as a synonym of "Synedra minutissima ß. KüTz.

Table 1. List of the main species identified in slide BM 18149 using modern literature (i.e. Krammer \& Lange-Bertalot 1986; Levkov 2009; Hofmann et al. 2011).

\begin{tabular}{|c|c|c|}
\hline Species & $\begin{array}{c}\text { Number of } \\
\text { valves }\end{array}$ & $\%$ \\
\hline Mayamaea atomus (KÜTZ.) LANGE-BERTALOT & 83 & 38.6 \\
\hline Mayamaea permitis (Hust.) BRuder et MEdLIN & 61 & 28.4 \\
\hline Halamphora minutissima (KüTZ.) C.E. WeTZEL ET COMPÈre comb. nov. & 25 & 11.6 \\
\hline Nitzschia frustulum (KÜTz.) GRUNOW & 18 & 8.4 \\
\hline Navicula wiesneri LANGE-BERT. & 13 & 6.0 \\
\hline Nitzschia pusilla (KÜTz.) LANGE-BERT. & 6 & 2.8 \\
\hline Halamphora montana (KRASSKE) LEVKOV & 6 & 2.8 \\
\hline Achnanthidium minutissimum (KüTZ.) CZARn. & 2 & 0.9 \\
\hline Navicula cryptocephala KüTz. & 1 & 0.5 \\
\hline Amphora sp. & - & Present \\
\hline Brachysira intermedia (ØSTRUP) LANGE-BERT. & - & Present \\
\hline Denticula tenuis KüTZ. & - & Present \\
\hline Gomphonema parvulum KüTz. & - & Present \\
\hline Navicula veneta KüтZ. & - & Present \\
\hline Planothidium lanceolatum (BRÉB.) LANGE-BERT. & - & Present \\
\hline Stauroforma exiguiformis (LANGE-BERT.) FlowER et al. & - & Present \\
\hline Surirella lacrimula ENGLISH & - & Present \\
\hline Total valves $=$ & 215 & \\
\hline
\end{tabular}



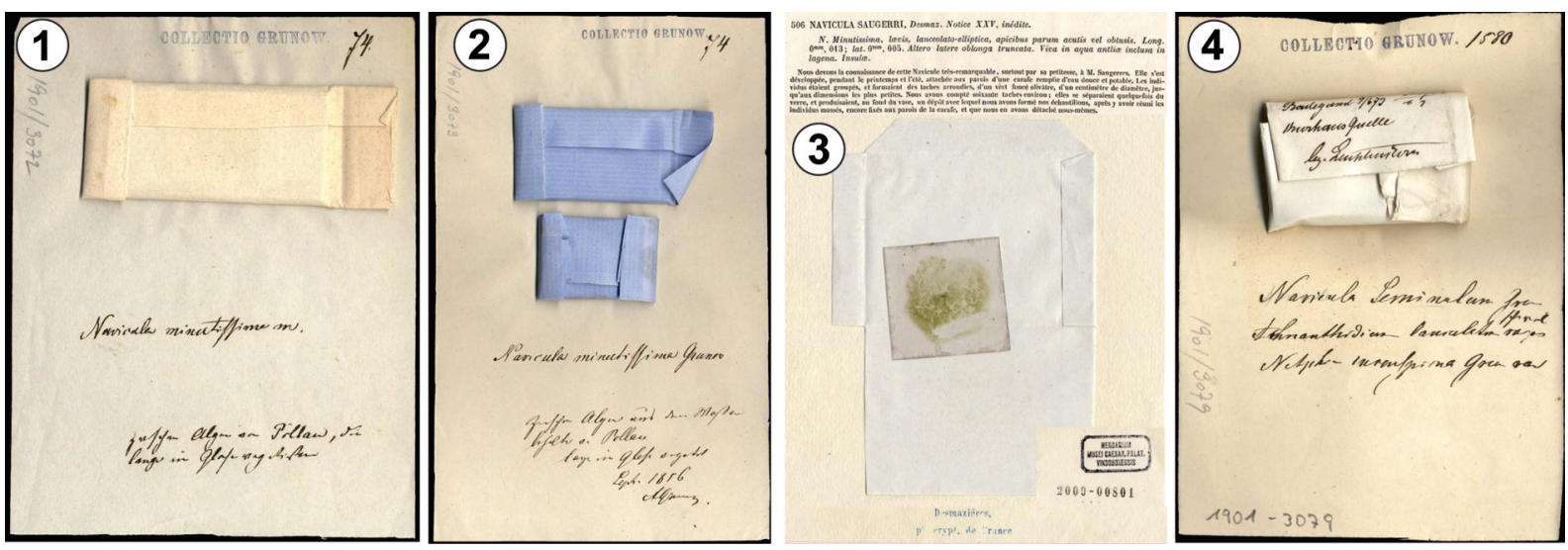

Figs 1-4. Original material (exsiccatae) deposited at the Naturhistorisches Museum Wien (W), Vienna, Austria, and here investigated: (1) Navicula minutissima Grunow (1860) material n 74; (2) Navicula minutissima Grunow material n 74; (3) Navicula saugerresii Desmaz. (1858) ('saugerri'), exsiccata ${ }^{\circ} 50 ;$ (4) Navicula seminulum Grunow (1860) material $\mathrm{n}^{\circ} 1580$.

Spec. Alg.”. However, BrÉBISSON's material was studied in detail by Schoeman et al. (1976) and concerns the species nowadays identified as Fistulifera pelliculosa (BRÉB.) LANGE-BERT. Unfortunately no material of Navicula minutissima RABENH. could be found in the collections in Bremerhaven (BRM / F. Hinz pers. comm.), Philadelphia (ANSP / M. Potapova pers. comm.), Meise (BR / B. VAN DE ViJVer pers. comm.), Leiden (L / NiCOLIEN Sol pers. comm.), Harvard (FH / R. EDGAR pers. comm.) or London (BM). The species is not mentioned in the species list from the Farlow Reference Library and Herbarium of Cryptogamic Botany, Harvard University (FH), which contains Rabenhorst exsiccatae (Algen Sachsens \& Europa's and Bacillarien Sachsens: http://www2.huh.harvard.edu/diatom). The taxon is not mentioned by KocioleK (2004), confirming that Navicula minutissima RABENH. is not present in RABENHORST's Algen Europa's exsiccata set.

In the same year that RABENHORST described $N$. minutissima, Sмітн (1853, p. 70, pl. 11, fig. 87) identified $S$. minutissima from a freshwater sample collected in Birkenhead (Merseyside, England), with a question mark in his reference to KüTZING (1844). W. SмITH 1.c. clearly illustrated a species belonging to Synedra/Ulnaria or Fragilaria and this was treated under Synedra by De Toni (1892, p. 652).

Ross (1947, p. 194) also examined "Kützing original gathering from 'Francolino am Po Ufer" material of S. minutissima housed at the Natural History Museum (BM[NH]) and observed that the species was "the same as Navicula seminulum var. fragilarioides Grunow apud VAN Heurck" illustrated by VAN Heurck (1880, pl. 14, fig. 10). However, as far as we know, the original material of Navicula seminulum var. fragilarioides has never been studied in detail by SEM. Moreover, important comments concerning $N$. seminulum var. fragilarioides provided by RABENHORST (1872, Algen Europa's, Exsiccata ${ }^{\circ} 2361$, Meeresgrundprobe) indicate that this taxon is a colony forming species and probably belongs to the genus Diadesmis KüTz., ac- cording to material from "Chile, Meeresgrundprobe, Corral ('Carral') bei Valdivia". He wrote:

"Ist nicht von meiner Nav. seminulum bei den stärksten Vergrösserungen zu unterscheiden, die Frusteln sind aber bis zu 8 bandförmig verbunden, weshalb die Form auch als Diadesmis zu betrachten wäre"... "Die zuerst aufgeführte Navicula oder Diadesmis hat am meisten Ähnlichkeit mit Diadesmis gallica Smith...". ${ }^{1}$

We could find few further interpretations of the variety fragilarioides in the literature. Exceptions are two older accounts, one by GERMAIN (1935), from aerophytic material collected at the "caves du Musée Saint-Jean, à Angers", France, and the other by HusTEDT (1962, p. 243). While GERMAIN 1.c. recognised it as a variety distinct from typical $N$. seminulum, HusTEDT 1.c. treated the variety fragilarioides as synonym of $N$. seminulum, based on the illustration provided by VAN Heurck (1880, pl. 14, fig. 10). The following comment was made by Hustedt (1962) about $N$. seminulum and the var. fragilarioides:

"Bei lebhaften Wachstum tritt häufig Bänderbildung ein, die zur Aufstellung der var. fragilarioides geführt hat, die also nur einen Wachstumszustand darstellt und daher nicht als besondere Variante abgetrennt werden kann."'

More recent accounts place var. fragilarioides as a synonym of Navicula seminulum (i.e. GERMAIN 1981, p. 230, pl. 84, fig. 22; KRAMMER \& LANGE-BERTALOT 1986, p. 230). However, further investigation is necessary to reveal the identity of Navicula seminulum var. fragilarioides, which remains unclear.

In slide BM 18149, made from the original ga-

\footnotetext{
1) Free translation: "It is not distinguishable from my Nav. seminulum at the highest magnification, the frustules are connected in ribbons of up to 8 cells, thus the form could also be regarded as Diadesmis"... "The Navicula or Diadesmis listed has most resemblance to Diadesmis gallica Smith".

$\left.{ }^{2}\right)$ Free translation: "Fresh material often forming bands, leading to the formation of the var. fragilarioides, which is thus only a growth condition and therefore cannot be separated as a special variant".
} 


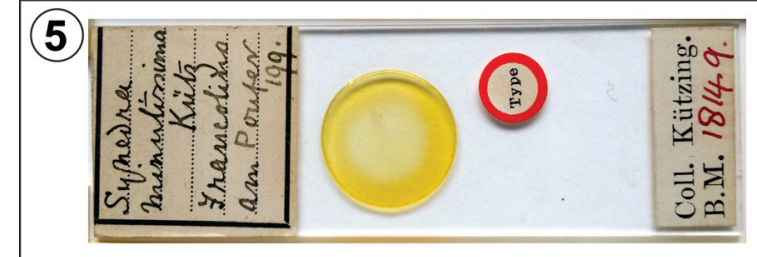

6) 2. SYNEDRA? MINUTISSIMA. Taf. 3. Fig. XXX. $\left(\frac{4}{1}^{0}\right)$. S. minutissima, latere primario angustissime linearis, secundario lanceolata obtusiuscula.

Unter einer Oscillaria bei Francolino am $\mathbf{P}_{0}$ ufer an der Strasse nach Ferrara. 1835. - Länge $\overline{2} \frac{1}{2} \overline{0} " 1 !$.

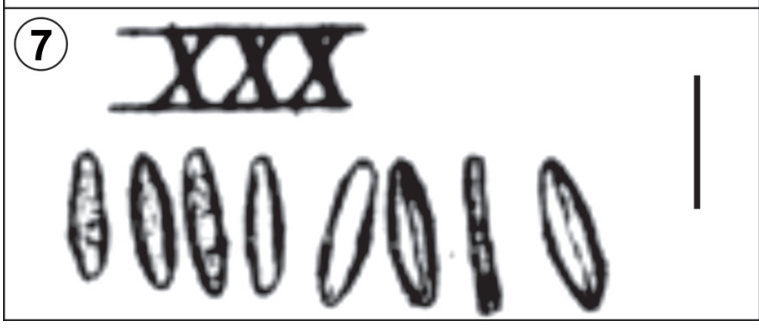

Figs 5-7. Halamphora minutissima comb. nov. (= Synedra minutissima Kütz.): (5) Slide BM 18149 from Francolino; (6) Original description from KüTZING (1844, p. 33); (7) Original drawing from KütZING (1844, pl. 3, fig. 30). Scale bar $10 \mu \mathrm{m}$.

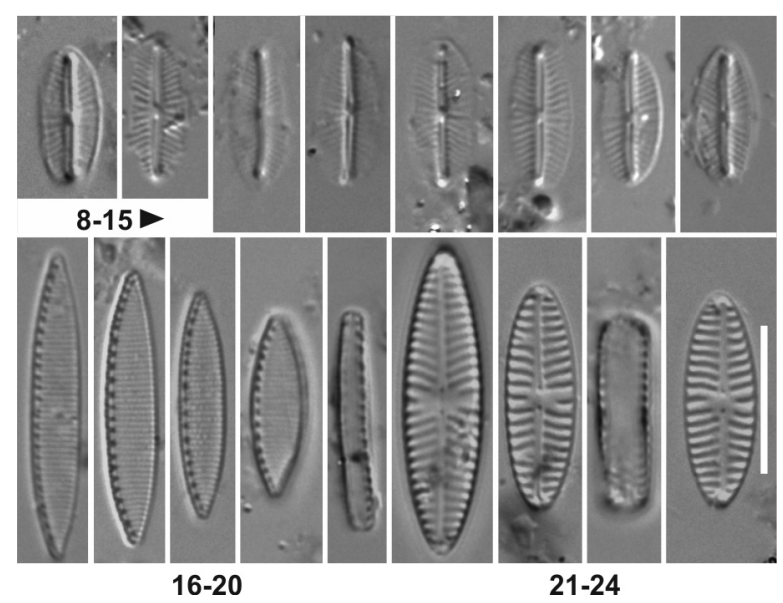

Figs 8-24. LM images of dominant species found in the type slide BM 18149: (8-15) Mayamaea atomus (KüTZ.) LANGE-BerT.; (1620) Nitzschia frustulum (KüTz.) GRUNow; (21-24) Navicula wiesneri LANGE-BERT. Scale bar $10 \mu \mathrm{m}$.

thering from the Po River (Italy) from which KützING described Synedra minutissima, we could not find any specimens that could be linked to Navicula minima, $N$. seminulum, $N$. seminulum var. fragilarioides sensu auct. nonnull., or to the genera Diadesmis or Humidophila according to current concepts (i.e. KRAMMER \& Lange-Bertalot 1986, Hofmann et al. 2011, Lowe et al. 2014). Nor could we find such specimens during the SEM analysis of the original gathering.

Instead, amongst the common species on slide BM 18149, there is a small hyaline amphoroid diatom with a relative abundance of $11.6 \%$. This seems to correspond well to the illustrations provided by KüTZING 1.c., and agrees with the protologue in terms of dimensions. For example the irregular valve outline and the eccentric longitudinal line (raphe) correspond to the LM images illustrated here in Figures 25-41. SEM images of this diatom clearly show dorsiventral amphoroid cells (e.g. Fig. 42), as well as some that are more naviculoid and may represent initial cells (Fig. 43). The agreement between KüTZING's account of $S$. minutissima and the small amphoroid species is sufficiently good to justify designating material from the type slide BM18149 as the lectotype of S. minutissima and the species is transferred to the genus Halamphora (Cleve) Levkov:

Halamphora minutissima (Kütz.) C.E. Wetzel et P. COMPÈRE comb. nov. (Figs 25-43)

Basionym: 'Synedra? minutissima' KüTz. 1844, Die kieselschaligen Bacillarien oder Diatomeen, p. 63, pl. 3, fig. 33, nec Synedra minutissima W. Sмгтн, 1853, Synopsis of British Diatomaceae, $\mathrm{p}$. 70, pl. 11, fig. 87.

Synonym: - Navicula minima Grunow in VAN HeURCK 1880, Synopsis des Diatomées de Belgique. Atlas, pl. 14, fig. 15, 1880 (Text: VAN HeURCK 1885, p. 107).

Lectotype (designated here): Slide BM18149, 'Coll KÜTZING' prep. 199, housed in the Natural History Museum (BM), London (Fig. 5).

Type locality: Italy, Po River, close to Ferrara ('Francolino am Po Ufer').

Remarks: Based on their diminutive cell size and high stria density, the most similar species presented in LEVKOV (2009) are Halamphora obscura (KRASSKE) Levкоv (2009, pl. 97, figs 23-33, pl. 98, figs 21-28) and Halamphora tenerrima (Aleem et Hust.) Levkov (2009, pl. 90, figs 51-59). Halamphora dagmarobbelsiana VAN de ViJver et LeVkov in VAN DE ViJver et al. (2014, fig. 8A-J), a recently described species from the Antarctic region (Île Amsterdam), also shows similarities with $H$. minutissima using LM. However, ultrastructural differences in the areolae of both ventral and dorsal striae separate these species.

List of valid, legitimate recognized species and their synonyms

Sellaphora aggerica (E. REICHARDT) FALASCo et EcTOR in FALASCo et al. (2009) (Figs 44-76)

Basionym: Navicula aggerica E. REICHARDT 1982, Ber. Bayer. Bot. Ges., vol. 53, p. 101, pl. 1, figs 25-33, pl. 4, figs 9-11.

Synonym: - Navicula minutissima (KüTz.) Grunow 1860, typo excl., nom. illeg. Verh. zool.-bot. Ges. Wien, vol. 10, p. 552, pl. 4, fig. 2a-e.

Remarks: Material labelled "Navicula minutissima" (Figs 1, 2) was obtained from the Naturhistorisches Museum in Vienna (GRUNOW collection $n^{\circ} 74$ ) and contains a monoculture of small cells with linear valves and with rounded ends (Figs 44-56). Valve lengths are $7.4-16.7 \mu \mathrm{m}$ and widths $3.2-3.5 \mu \mathrm{m}$. The raphe is 

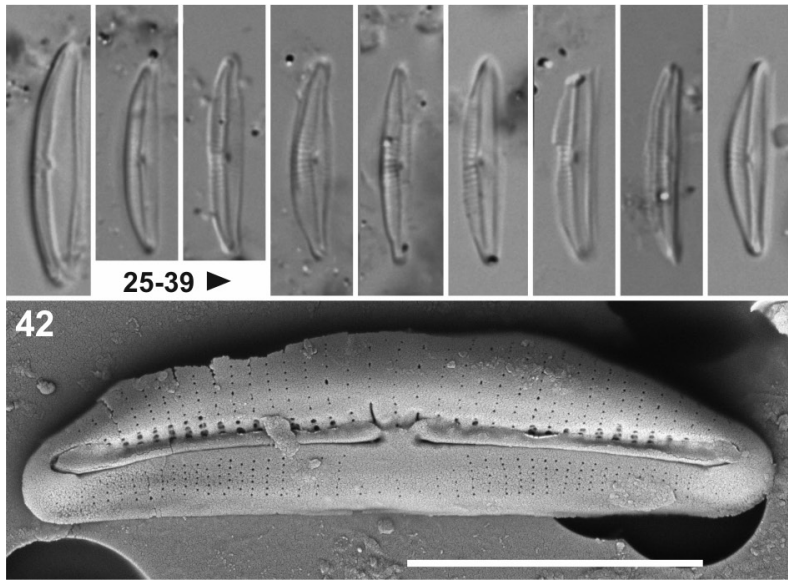
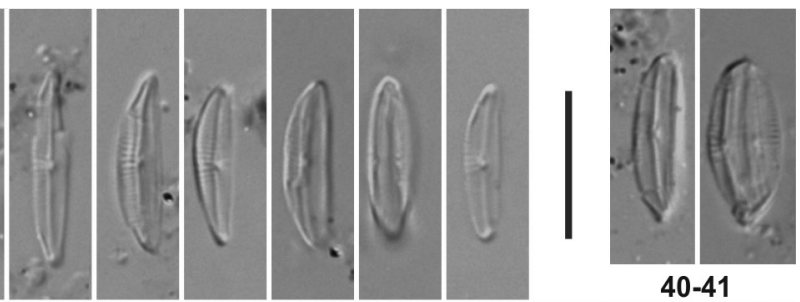

43

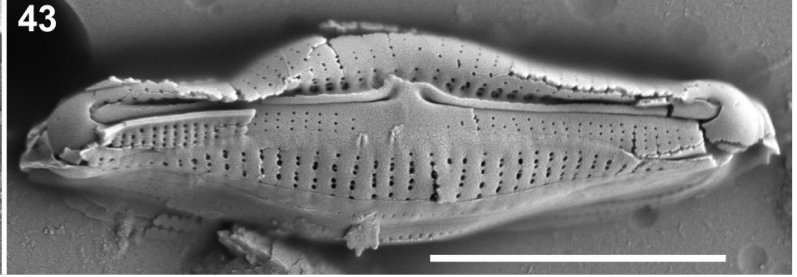

Figs 25-43. Halamphora minutissima comb. nov. (= Synedra minutissima KüTz.): (25-41) LM images of slide BM 18149; (42-43) External SEM images from the raw material. Scale bars $10 \mu \mathrm{m}(25-41), 5 \mu \mathrm{m}$ (42 and 43).

filiform and straight, with the external ends bent towards the primary side of the valve (Figs 59, 60). The raphe sternum is flanked by longitudinal irregular grooves (Figs 59, 60), which are often visible under LM as longitudinal lines and are interrupted opposite the central area. The central area is very variable: irregular and wide in larger cells (Figs 44, 59), much reduced in smaller specimens (Figs 56, 60). The striae are often visible in LM, slightly radiate, $24-29$ in $10 \mu \mathrm{m}$, becoming sparser and sometimes alternating irregularly, shorter and longer, in the central area. They are uniseriate, each composed of 7-12 irregularly shaped (usually round), coarse pores (Figs 59-65) and they are not interrupted on the valve mantle (Fig. 61). Internally the areolae are occluded by hymenes. The distal raphe ending forms a small helictoglossa internally. A large rounded apical pit is present at both apices (Figs 63, $65)$; this is usually closed externally.

GrunOw (1860, p. 552) placed the name Synedra minutissima KüTz. as a synonym of his "Navicula minutissima". GRUNOw's illustrations show a naviculoid species with bluntly rounded poles, linear valves with parallel margins, a 'central nodule' and a raphe (GRUNOW 1860, pl. 2, fig. 2a-d) and these features agree with our observations from the original material. However, N. minutissima (KüTz.) GRUNOw 1860 is illegitimate, being a later homonym of $N$. minutissima RABENH. 1853. The name was therefore changed to N. minima by Grunow himself, in the Synopsis des Diatomées de Belgique (VAN Heurck 1880). Thus $N$. minutissima GRUNOW (non RABENH.) is a nomenclatural synonym of $N$. minima and both names have the same type, which is the type of Synedra minutissima Kütz. (= Halamphora minutissima comb. nov.).

As a logical consequence the name Navicula minutissima (KÜTz.) GRUNOw has been regarded as a synonym of Navicula minima in previous publications (e.g. Cleve 1894, p. 128; Hustedt 1962, p. 249; Krammer \& LANGE-Bertalot 1986, p. 229). However, analysis of the material of Navicula minutissima that GRUNOw used to write his 1860 account and that of Navicula minima used by GRUNOw to prepare his 1880 drawings (in VAN HEURCK 1880) shows that these represent two distinct species, as detailed below. Thus, even if the names were usable in the senses that GRUNOw intended, taxonomic synonymization would be inappropriate, since GRUNOw's material of Navicula minutissima does not correspond to any of the species around 'Navicula minima' complex. Instead, GRUNOw's material is the same as the species described by REICHARDT (1982) as Navicula aggerica E. REICHARDT, currently placed in Sellaphora (FALASCO et al. 2009). The type material of Navicula aggerica was recently analysed by FALASCO et al. (2009) and our re-analysis in SEM of the original material (Figs 66-76) shows that the species is morphologically similar to the original material of $N$. minutissima GrunOw (Figs 59-65) and we thus consider both conspecific. The Sellaphora stroemii (Hust.) H. Kobayasi in Mayama et al. (2002) (=Navicula stroemii Hust.) species-complex was recently studied in detail by FALASCO et al. (2009), who performed valve shape analysis using geometric morphometric methods on 96 specimens photographed from the type material. They concluded that S. aggerica (Figs 66-76), Sellaphora stroemii (Figs 77-86) and Sellaphora ventraloides (Hust.) Falasco et Ector in Falasco et al. (2009) (Figs 87-95) should be considered as separate taxa, distinct from the Indonesian species Sellaphora subbacillum (Hust.) FALAsco et Ector in FAlAsco et al. (2009) (Figs 96-102 and 110) [= Navicula vasta Hust. (Figs 103-109, 111)].

Sellaphora saugerresii (Desm.) C.E. Wetzel et D.G. MAnN comb. nov. (Figs 112-127, 251-269)

Basionym: Navicula saugerresii Desm. 1858, 'saugerri', Plantes Cryptogames de France, ed. 2(2), fasc. 11-12, exsiccata n ${ }^{\circ} 506$.

Synonyms: - Navicula minima Grunow in VAN Heurck 1880, pro parte, typo excl. Synopsis des Diatomées de Belgique. Atlas (Text: VAN HeURCK 1885, p. 107), pl. 14, fig. 15; = Navicula seminulum Grunow sensu Krammer \& Lange-Bertalot 1986, p. 230, pl. 76, figs 30-36; = Sellaphora seminulum (Grunow) D.G. MANN sensu 


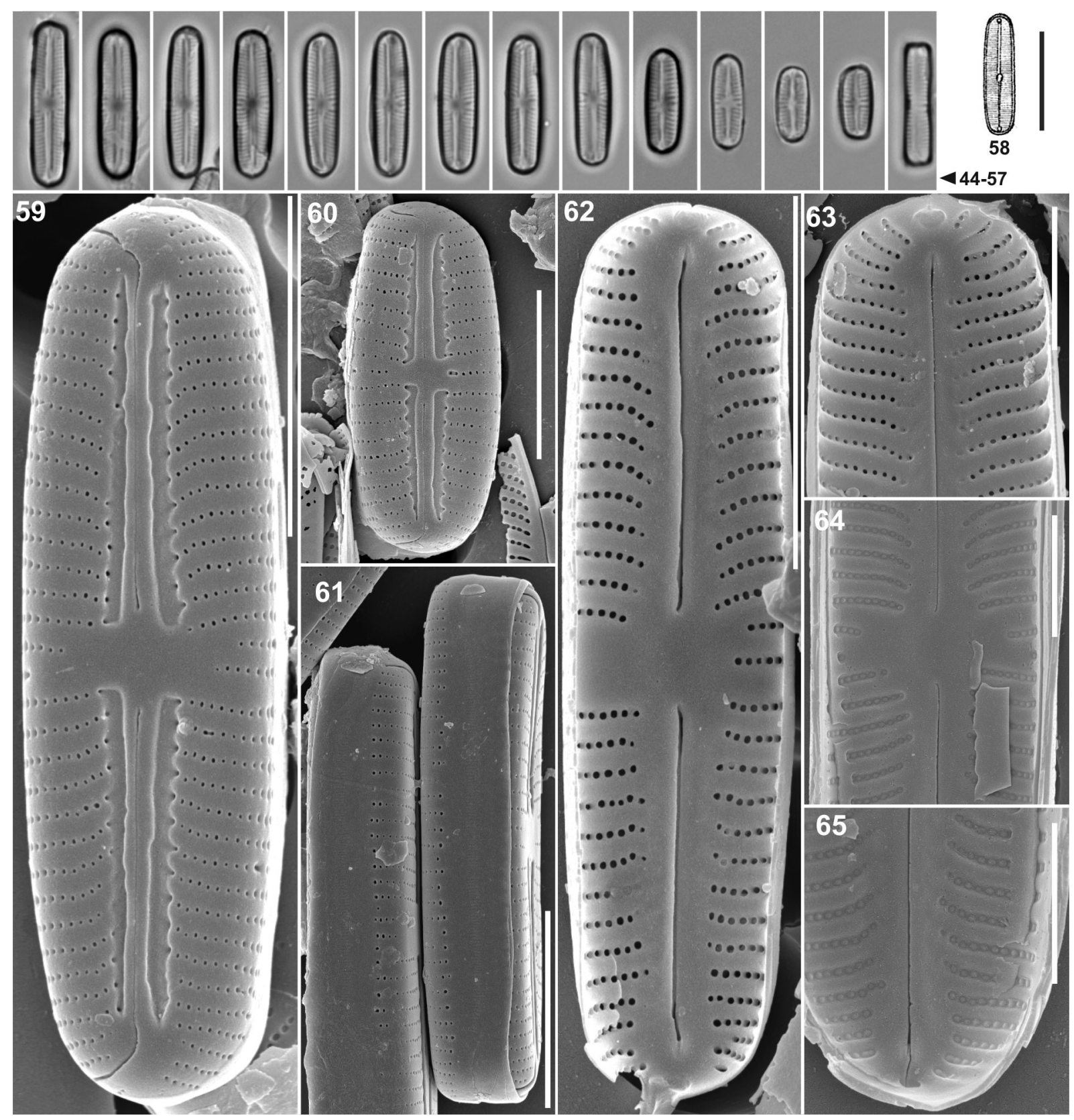

Figs 44-57, 59-65. LM and SEM images of Sellaphora aggerica (E. ReICHARDT) FALASCo et ECTOR (= Navicula minutissima Grunow 1860), material n⿳ 74 (acc. 1901/3072 and 1901/3073) from Grunow collection (W). Fig. 58. Original drawing of Navicula minutissima from Grunow (1860, pl. 4, fig. 2e). Scale bars $10 \mu \mathrm{m}$ (44-58), $5 \mu \mathrm{m}$ (59, 61 and 62), $4 \mu \mathrm{m}$ (60), $2 \mu \mathrm{m}$ (63-65).

Hofmann et al. 2011, p. 537, pl. 42, figs 22-26); = Sellaphora styxii P.M. Novis, J. Braidwood et C. Kilroy 2012, Phytotaxa, vol. 64, p. 34. figs 130-147.

Lectotype (designated here): preparation BR-4395 (Botanic Garden Meise, BR, Belgium) from exsiccata $\mathrm{n}^{\circ} 506$ of DESMAZIÈRES.

Remarks: In his contributions to the cryptogamic flora of France, Desmazières (1858) communicated a new species called Navicula saugerresii DesMAZIÈRES (as 'saugerri', but the person commemorated was 'Monsieur Saugerres', so that the epithet should be corrected to saugerresii [see ICN art. 60.12 , rec. $60 \mathrm{C} 1$ : MCNEILL et al. 2012]). The material contains solitary cells with isopolar frustules and a shallow mantle (Figs 112127). Cell dimensions are as follows: length 6.5-11.0 $\mu \mathrm{m}$, width $3.3-3.8 \mu \mathrm{m}$, striae $21-22$ in $10 \mu \mathrm{m}$. The valves are linear-elliptical or linear-lanceolate with rounded poles. In girdle view, cells are \pm rectangular with a shallow mantle (Fig. 127). The striae are visible in LM, slightly radial at the centre, becoming more parallel towards the poles (Figs 112-126), with a very narrow axial area, which is linear over most of the valve (Figs 112-116). The areolae are not discernible in LM (with bright field), but in SEM the striae can be seen to be uni- to biseriate and radiate throughout (bordering the raphe they are generally uniseriate but they 


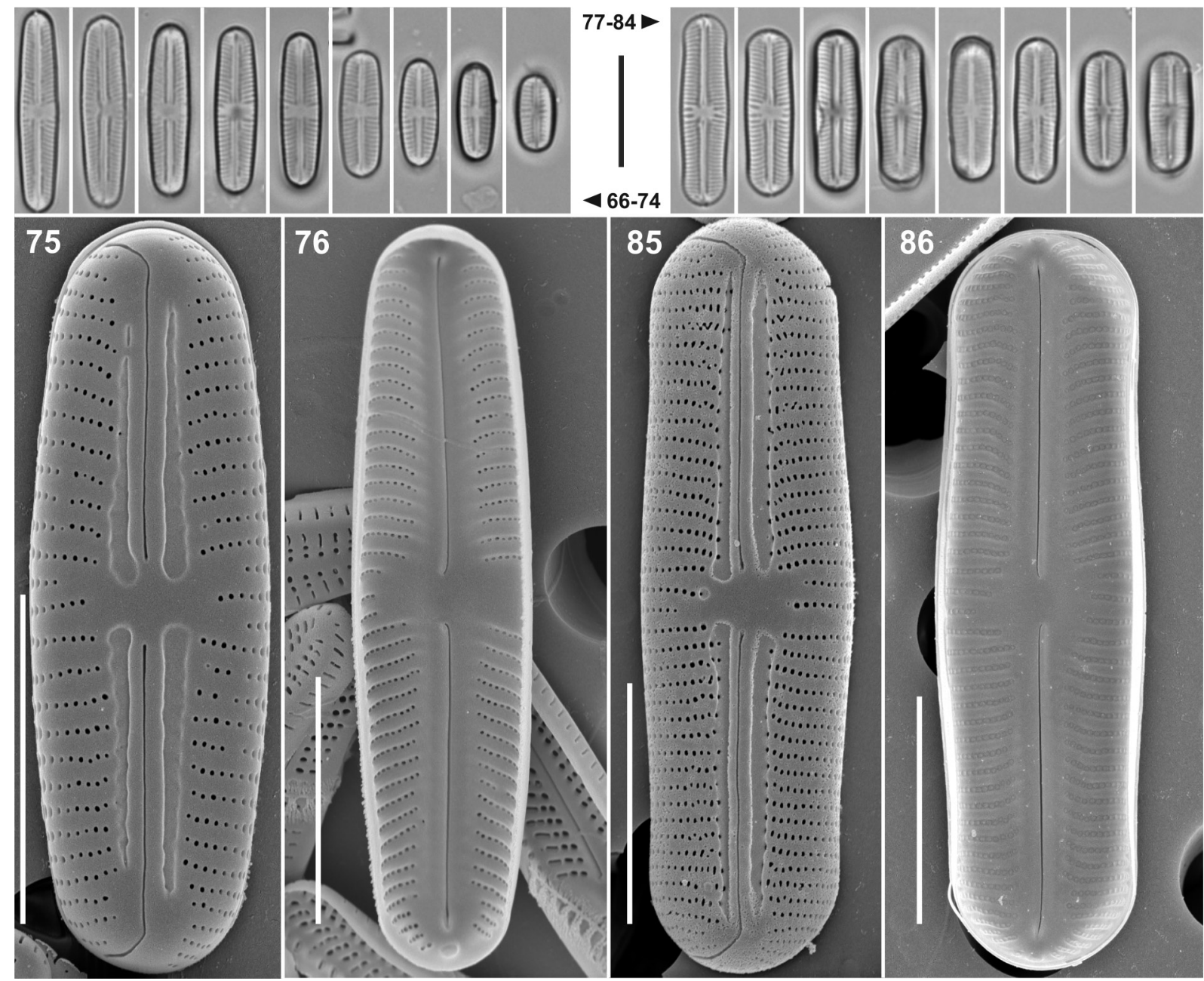

Figs 66-86. LM and SEM images: (66-76) Sellaphora aggerica (E. REICHARDT) FALASCO et Ector, original material (Sample S61-T01) from the Steinerne Rinne (Germany); (77-86) Sellaphora stroemii (Hust.) D.G. Mann, sample E2541 from Feforvatn (Norway). Scale bars $10 \mu \mathrm{m}$ (66-74, 77-84), $5 \mu \mathrm{m}(75,76,85$ and 86$)$.

become biseriate towards the mantle), containing tiny round poroids (Figs 251-255). The striae bordering the central area - which is wide, symmetrical, bow-tie shaped, and usually extends to close to the junction of valve face and mantle - are slightly but noticeably curved; two to three shorter striae, often uneven in length, are present in the very middle of the valve. The striae extend down onto the shallow mantle (Fig. 256). The raphe is straight with tear-drop-shaped proximal fissures, which are slightly curved, and it has distal fissures that bend strongly to the same side of the valve towards the valve mantle (Figs 251-254). Internally, the proximal raphe fissures are slightly deflected to the same side (Figs 257, 258) and the distal raphe fissures ends in a reduced helictoglossa (Fig. 259). Internally, a large round pit can be seen at each apex (Fig. 259), which is usually occluded externally (Fig. 260). Each areola is internally occluded by a hymen. The girdle bands lack areolae (not shown).

Our illustrations are the first to show the type material of Desmazières. Navicula sangerresii is usually placed as a synonym in the 'minima-minutissi- ma-seminulum' complex (e.g. Cleve 1894, Hustedt 1962, Krammer \& Lange-Bertalot 1986). The original material from Desmazières (1858) exsiccata $n^{\circ}$ 506 seems to be a monospecific culture of $N$. saugerresii, which Desmazières described as: "N. minutissima, laevis, lanceolato-elliptica, apicibus parum acutis vel obtusis. Long. $0.013 \mathrm{~mm}$; lat. $0.005 \mathrm{~mm}$. Altero latere oblonga truncata. Viva in aqua antlice inclusa in lage$n a$ ". Around 60 green-olive colonies of $1 \mathrm{~cm}$ diameter were growing in a bottle of drinking water according to a detailed description on DesmaziÈREs' exsiccata (Fig. 3). A few years later, RABenhorst (1864, p. 173) reproduced the short description of the species, while GRUNOW (in VAN HeURCK 1880, pl. 14, fig. 8a) provided several illustrations of valves but no measurements or description. Navicula saugerresii was listed as a doubtful synonym of $N$. seminulum by KRAMmer \& LANGEBERTALOT (1986, p. 230), who were unsure about which name had nomenclatural priority:

"Zur Nomenklatur bleibt weiterhin offen, ob N. seminulum oder N. saugerrii Priorität besitz, weil sich das Jahr der Veröffentlichung des Exsikkates no. 506 von 


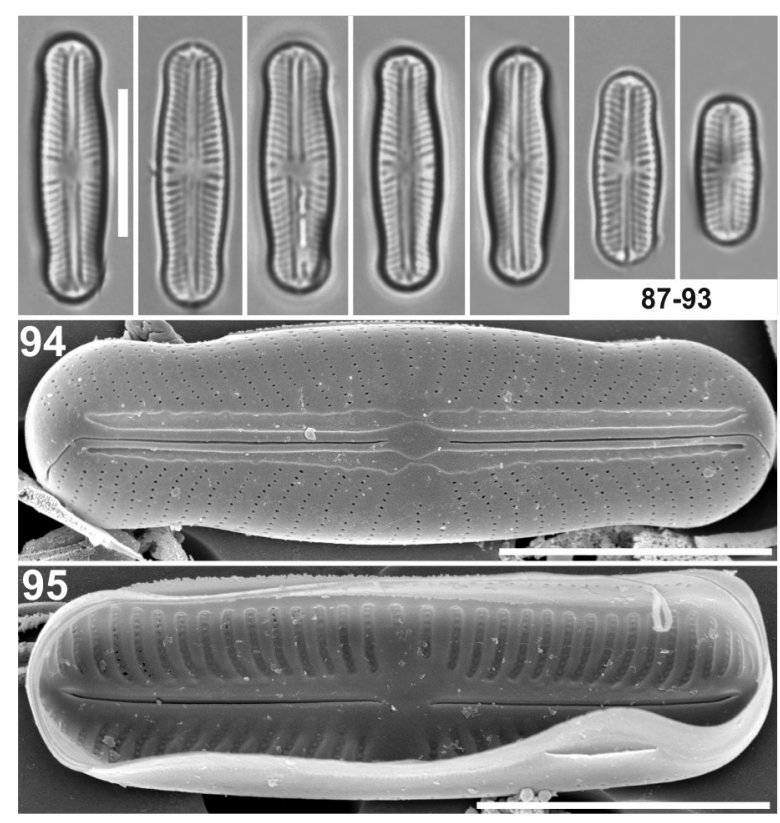

Figs 87-95. Sellaphora ventraloides (Hust.) FaLASCO et Ector, sample E761 from Plitvice Lakes National Park 'Plitvicer Seen' (Croatia). Scale bars $10 \mu \mathrm{m}$ (87-93), $5 \mu \mathrm{m}$ (94 and 95).

Desmazières (Plantes Cryptogames de France) sowie die Notiz 25 in Annales des Sciences bisher nicht genau datieren ließen"3.

However, the date of issue of exsiccata $n^{\circ} 506$ (in fascicles 11-12 of Desmazières' exsiccatae) was 20 March 1858, according to the "Nouvelle édition des Plantes Cryptogamiques de France" (given in SAYRE 1969). Navicula saugerresii is therefore earlier than both $N$. seminulum and $N$. minima, which were published in 1860 and 1880, respectively. Moreover, N. seminulum and $N$. saugerresii are clearly distinct species. In contrast the conspecificity of $N$. minima sensu GRUNOW in VAN HeURCK 1880 and Navicula saugerresii is beyond doubt and we consider them to be synonyms, as detailed below.

The name "Navicula saugerri var. striis tenuioribus?' is presented as a synonym of 'Synedra pusilla KG.!' in Van Heurck (1880, pl. 14, fig. 16b). This species was identified by Lange-Bertalot (1976) as Nitzschia pusilla (KüTz.) Grunow emend. LANGE-BerT.

Authenticated material (i.e. material that Grunow agreed corresponded to his concept of $N$. minima) of $N$. minima in VAN HEURCK sample $\mathrm{n}^{\circ}$ 142, VAn Heurck collection, Botanic Garden Meise (BR), contains a monoculture of small-celled solitary specimens with a general outline and ultrastructural characteristics similar to those of $N$. saugerresii described above; these are illustrated here in Figures 128-142 and 261-269. Like N. saugerresii, Grunow's

\footnotetext{
$\left.{ }^{3}\right)$ Free translation: "The nomenclature is still unclear whether $\mathrm{N}$. seminulum or N. saugerrii has priority, because the year of publication of the Exsiccata $n^{\circ} 506$ of Desmazières (Plantes Cryptogames de France), in the note 25 of the Annales des Sciences has not previously been precisely dated".
}
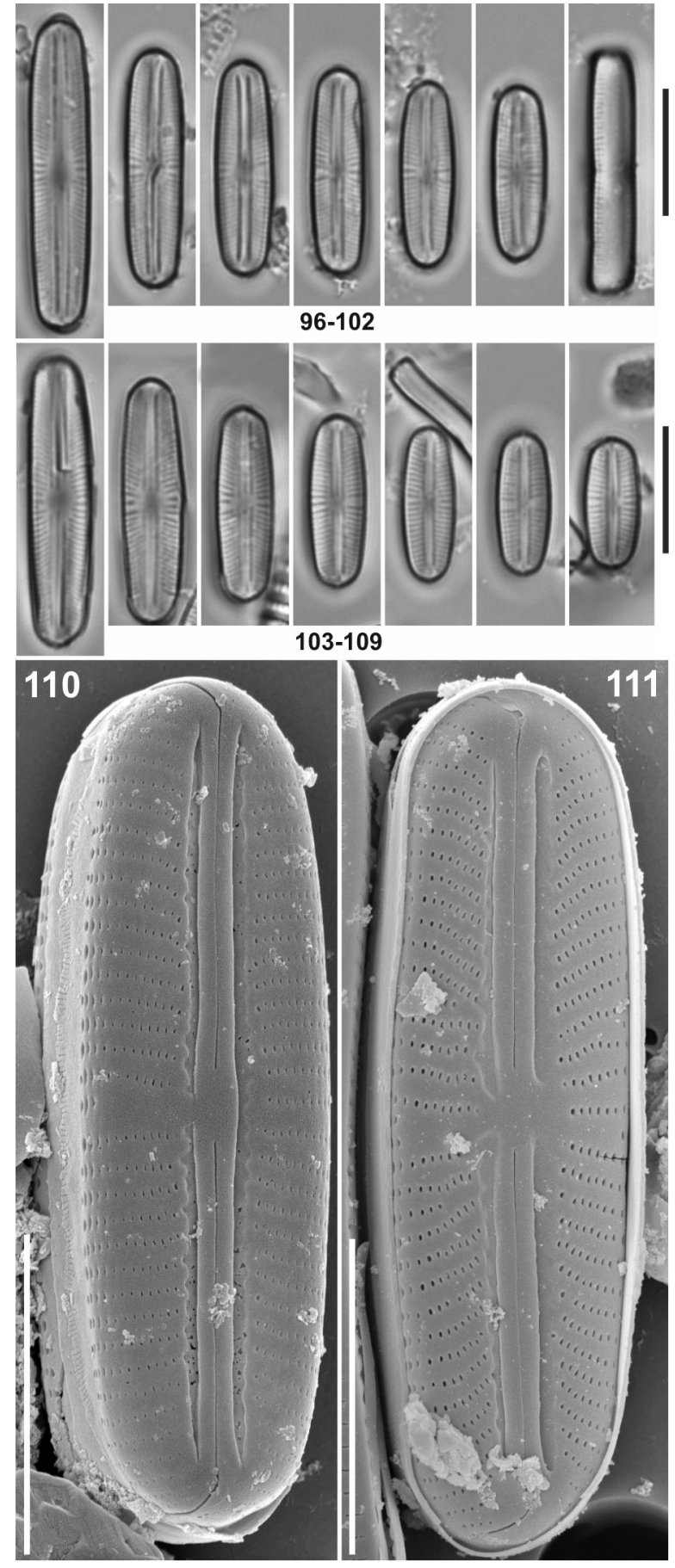

Figs 96-102, 110, 111. Sellaphora subbacillum (Hust.) Falasco et ECTOR, sample AS726 from Singkarak (Sumatra). Figs 103-109, 111. Syn. Navicula vasta Hust., sample AS325 from Tengger-Massiv (Java). Scale bars $10 \mu \mathrm{m}(96-109), 5 \mu \mathrm{m}$ (110 and 111).

N. minima was collected from a bottle of freshwater ("Eaux douces. Bruxelles, dans une carafe") but the cells are slightly longer $(9.5-14.5 \mu \mathrm{m}$ instead of $6.5-$ $11.0 \mu \mathrm{m})$ and wider $(3.4-4.2 \mu \mathrm{m}$ instead of 3.3-3.8 $\mu \mathrm{m})$. In addition, the striae are more consistently biseriate throughout the valve in the material of ' $N$. $m i$ nima', although some striae bordering the central area can be uniseriate (e.g. Figs 261, 262, 264). The central area usually exhibits a rectangular to 'bow-tie' outline, 
due to the presence of two or three short striae in the middle. The striae are not interrupted at the junction of valve face and mantle and continue for a short distance onto the shallow mantle (Figs 264-266). Due to the relatively poor condition of the sample (eroded frustules), areola occlusions could not be observed ${ }^{4}$. The raphe is similar in the Brussels sample of ' $N$. minima' and $N$. saugerresii, including the presence of a small helictoglossa and a large apical pit (Fig. 269).

The name Navicula minima appears for the first time in the Atlas of VAN Heurck (1880) as a replacement name for Navicula minutissima (KüTz.) GRUNow, as discussed above, and nowadays many illustrations of N. minima in the literature are identified as "Navicula seminulum" (e.g. Schoeman \& Archibald 1977; Krammer \& Lange-Bertalot 1986, pl. 76, figs 3036; Hofmann et al. 2011, pl. 42, figs 22-26, among others). However, the material in VAN HeURCK type ${ }^{\circ}$ 142 does not allow any doubt concerning the identity of Grunow's N. minima (which Van Heurck 1885, p. 107, described as having "Valve linéaire à extrémités arrondies; stries radiantes"), since it is the only species present in the sample "Type 142" analysed by us. Even though sample $\mathrm{n}^{\circ} 142$ had already been observed and illustrated by PATRICK \& ReIMER (1975, pl. 46, figs $17-18$ as Navicula minima var. minima), Schoeman \& Archibald (1977, figs 4-6, as Navicula seminulum) and Weber \& McFarland (1981, fig. 5a-c, as "N. seminulum Grun. var. hustedtii PATR."), the morphological concept of ' $N$. minima', and hence of Eolimna, has remained blurred because the illustrations show a diatom that corresponds to the prevalent concept of 'Sellaphora seminulum', which in fact is a different species (see below). The type material of Navicula minima GRUNow var. hustedtii R.M. PATRICK (1959) was recently observed by PотAPOVA (2013, p. 12, fig. 54): "There are, however, several specimens on the holotype slide that have the same characters, except lower stria density. It is likely that $\mathrm{N}$. seminulum var. hustedtii belongs to the Eolimna minima/Sellaphora seminulum species complex, but its identity will probably remain unresolved as it is extremely rare in the type material".

Sellaphora crassulexigua (E. ReICHARDT) C.E. Wetzel et Ector comb. nov. (Figs 143-157, 270294)

Basionym: Navicula crassulexigua E. ReICHARDt 1994, Ber. Bayer. Bot. Ges., vol. 64, p. 130, pl. 3, figs 4-11, 28, 29.

Synonym: $\equiv$ Eolimna crassulexigua (E. ReICHARDT) E. REICHARDT 2011, Ber. Bayer. Bot. Ges., vol. 81, p. 15, figs 30, 122-124.

Remarks: The valves are linear-elliptical or linearlanceolate with rounded poles and striae that radiate at the centre (Figs 143-157). Cell dimensions measured by us in the type material are as follows: length 5.5-

\footnotetext{
$\left.{ }^{4}\right)$ It should be noted that the areolae were better preserved in the material of $N$. saugerresii than in $N$. minima, thus appearing different in LM.
}

$14.0 \mu \mathrm{m}$, width $2.7-4.4 \mu \mathrm{m}$, striae $17-23$ in $10 \mu \mathrm{m}$. The axial area is narrow and a large, usually slightly asymmetrical central area can be observed in large (Fig. 143) as well as in small specimens (Figs 155-157). SEM reveals that the striae are always uniseriate (Figs 288-294). The raphe is straight with slightly curved, tear-drop-like proximal fissures and distal fissures that bend strongly to the same side of the valve. Internally, the proximal raphe fissures are slightly deflected to the same side (Figs 288-290) and the distal raphe fissures end in a well-developed helictoglossa (Figs 291294). A large round pit is present at each apex (Figs 292, 293), occluded externally (Fig. 289). Each areola is occluded by a hymen internally. The girdle bands lack areolae (Fig. 289). The same striation patterns are found in material from a calcareous river in France (Figs 270-286) and from a cave in Italy (Fig. 287).

Sellaphora crassulexigua is very similar to $S$. saugerresii in LM and SEM, since they have the same cell size range and general valve outline. The main difference is in the striae, which are always uniseriate in S. crassulexigua and the areolae are smaller. ReICHARDT (1994) observed, however, that $S$. crassulexigua has a coarser striation pattern $(18-23$ in $10 \mu \mathrm{m})$ than in similar species. Moreover, in S. crassulexigua the central area is consistently asymmetrical, a feature readily visible in LM (Figs 143-157). Recently REICHARDT (2011, p. 15) has combined the species in the genus Eolimna, based on the raphe and hymen position. However, we can find no morphological basis for separating Eolimna crassulexigua (E. REICHARDT) E. REICHARDT from Sellaphora. In general the helictoglossae seem to be more pronounced in S. crassulexigua (Figs 145, 146, 291-294) than in $S$. saugerresii (Figs 257, 259, 260).

This species seems to be rare and restricted to springs (ReICHARDT, pers. comm.). The type material comes from a calcareous spring in Germany [Neumarkt in der Oberpfalz, Franconian Switzerland, ('Frankenjura')] (REICHARDT 1994), and was also observed in mountainous areas of tufa-forming springs and streams in the "Paterzeller Eibenwald" (an area with numerous yewtrees near Paterzell, Southern Bavaria) associated with taxa which are characteristic of oligotrophic or weakly mesotrophic habitats rich in lime (REICHARDT 2011).

We expand the distribution of the species with populations of $S$. crassulexigua from a calcareous spring area from which the Scie River arises ('Source de la Scie' at Saint-Maclou-de-Folleville) at Normandy, France (Figs 270-286) as well as aerial populations colonizing the wet and artificially illuminated calcareous concretion walls of the Bossea cave, SW Alps (NW Italy) (Fig. 287). Amphora pediculus (KüTz.) Grunow, Caloneis fontinalis (Grunow) Lange-Bert. et E. Reichardt, Navicula muraloides Hust., Navicula striolata (GRUNOW) LANGE-BerT., Naviculadicta jurafontinalis WeRUM et LANGE-BERT., N. schaumburgii Werum et Lange-Bert., Planothidium reichardtii 


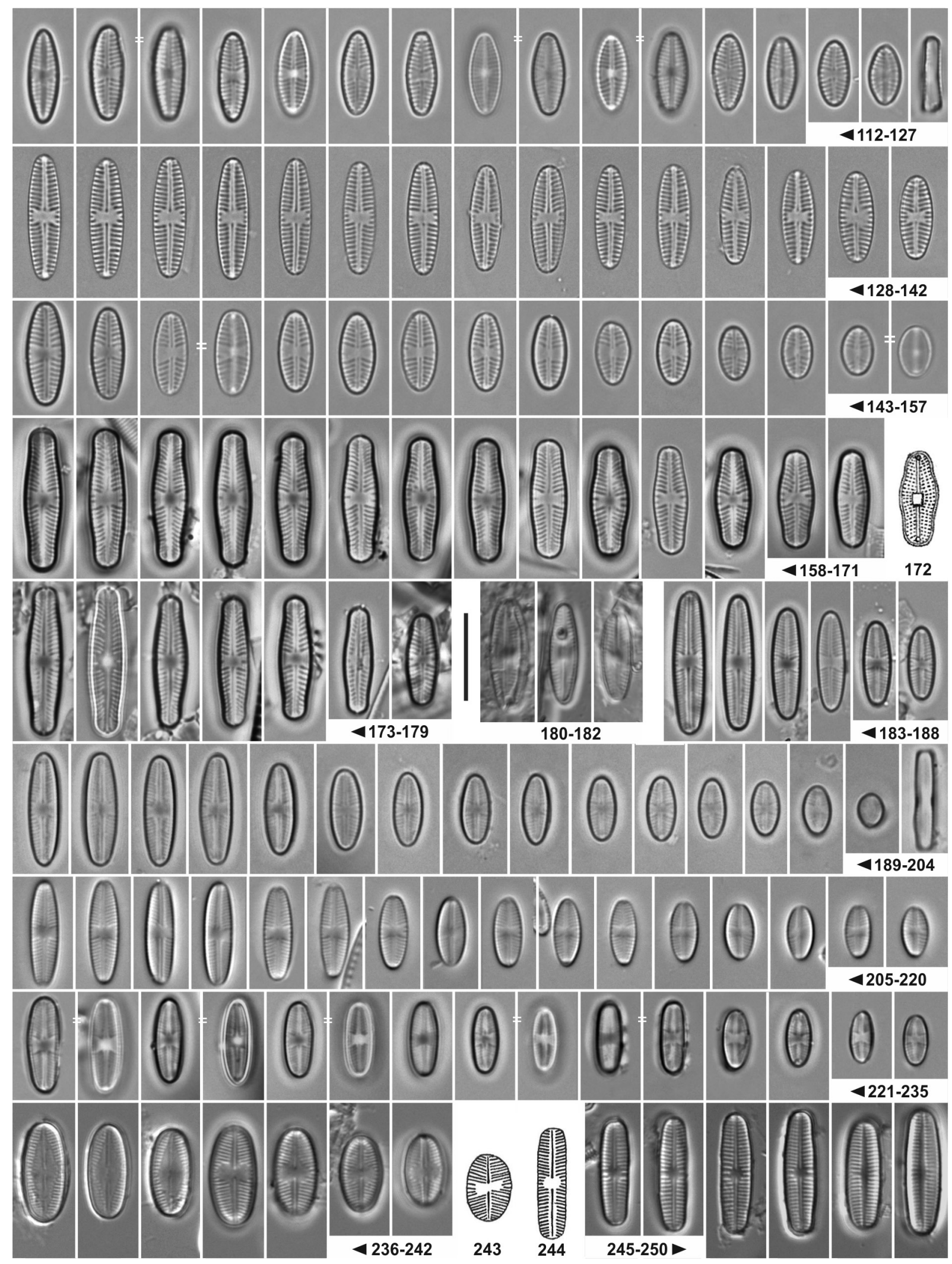

Figs 112-250. Sellaphora saugerresii comb. nov., (112-127) Navicula saugerresii DeSM. 1858, exsiccata $n^{\circ} 506$ from Grunow collection (W). Figs 128-142. Navicula minima Grunow in VAN Heurck (1880), slide "Type n 142" from Brussels, VAN Heurck collection (BR). Figs 143 157. Sellaphora crassulexigua comb. nov., sample n' ${ }^{\circ} 668-T 01$ from Oberpfalz, Bavaria (Germany), Reichardt collection. Figs $158-179$. Sellaphora seminulum (Grunow) D.G. MAnN: (158-165) Navicula seminulum Grunow (1860), material n ${ }^{\circ} 1580$ (Radegund, Liechtenstein) from Grunow collection (W); (166-171) Navicula seminulum Grunow in VAN Heurck (1880), sample "Type n 143" from Brussels, VAN Heurck collection (BR); (172) Navicula seminulum, original drawing from Grunow (1860, pl. 4, fig. 3e); (173-179) Navicula seminulum var. radiosa Hust. (1954), sample E5926 from Immerather Maar, Eifel, Rheinland-Pfalz (Germany). Figs 180-182. Sellaphora subseminulum comb. nov., slide N12/80 from 'Wenzen bei Göttingen' (Germany). Figs 183-235. Sellaphora atomoides comb. nov.: (183-188) Navicula tantula Hust. (1934a, b), sample E869 from Poggenpohls Moor, Niedersachsen (Germany); (189-220) Navicula atomoides Grunow in Van HeURCK 
LANGE-Bert. et Werum and Staurosirella ovata E. MoRALES are among the other species found in samples containing $S$. crassulexigua (WERUM \& LANGE-BERTALOT 2004, REICHARDT 2011).

\section{Sellaphora seminulum (Grunow) D.G. MANn (1989) (Figs 158-179, 295-301)}

Basionym: Navicula seminulum GRUNOw 1860, Verh. zool.-bot. Ges. Wien, vol. 10, p. 552, pl. 2, fig. 3a-d (non 2a-d), nec Navicula seminulum EhrenB. 1842, Ber. Bekanntm. Verh. Königl. Preuss. Akad. Wiss. Berlin, 1842, p. 265, nomen nudum.

Synonyms: = Navicula seminulum var. radiosa Hust. 1954, Arch. Hydrobiol., vol. 48, p. 473, figs 36, 37; = Navicula joubaudii $\mathrm{H}$. Germ. 1982, Cryptog. Algol., vol. 3, p. 36, pl. 2, figs 12-24; = Sellaphora radiosa (Hust.) H. Kobayasi in Mayama et al. 2002, Diatom, vol. 18, p. 90; = Sellaphora joubaudii (H. GERM.) ABOAL in ABOAL et al. 2003, Diatom Monographs, vol. 4, p. 433.

Remarks: The valves are linear-lanceolate to broadly lanceolate, with clearly convex margins (inflated in the middle) and protracted, broadly rounded, slightly rostrate ends (Figs 158-172). The frustules are 9.8-16.5 $\mu \mathrm{m}$ long and 3.4-4.4 $\mu \mathrm{m}$ wide $(n=30)$, and in girdle view they are rectangular. The valve face is flat and the mantle very shallow. The striae are markedly radiate and also arcuate, especially towards the apices, where they are also denser; they are uniseriate, or sometimes partially biseriate but only near the axial area (Figs 295, 296, 298, 301). The areolae are small and round and each is occluded by a hymen lying across its internal aperture (Fig. 300). The axial area (sternum) is linearlanceolate, with an irregular border, and is central or apparently very slightly displaced towards the secondary side (Figs 295-298). The central area is bordered by three shorter striae and is usually butterfly-shaped, but the size and shape vary. The raphe branches are slightly undulate externally and displaced towards the secondary side of the sternum; internally they are filiform and straight. The proximal (central) part of each raphe branch curves gently towards the primary side externally and the central raphe endings are slightly drop-like. Internally, the raphe branches remain slit-like as they approach the centre and are bent towards the primary side. Beyond the helictoglossa, a larger foramen-like (pit) can be seen (Figs 295, 300, 301) at the poles. Distal raphe endings strongly curved onto the mantle, towards the secondary side (Figs 295-298).

(1880), slide “Type n 219” from Anvers (Antwerp) (205-220 taken with differential interference contrast (DIC)), VAN HEURCK collection (BR); (221-235) Stauroneis fonticola Hust. (1937), sample AS1321, from Tengger mountains (Java). Figs 236-243. Psammothidium marginulatum (GRUNOw) BuKHT. et Round, as 'Navicula minima Grunow apud VAn Heurck var. atomoides (Grunow apud Van HeuRCK) Cleve' in Ross (1947, pl. 9, fig. 4, here reproduced as figure 9ec). Figs 244-250. Achnanthidium pusillum (Grunow) CZARn., as 'Navicula minima Grunow var. typica' nom. inval. in Ross (1947, pl. 9, fig. 5, here reproduced as fig. 244). Both specimens illustrated by Ross (1947) correspond to 'monoraphid' specimens from slide BM 35933 (Lake Harbour, Baffin Island, Canada). Scale bars $10 \mu \mathrm{m}$.
Samples of Navicula seminulum from both GRUNOw collection $n^{\circ} 1580$ (Naturhistorisches Museum Wien) (Figs 158-165) and the VAN HeUrCK collection (Type $\mathrm{n}^{\circ} 143$, Botanic Garden Meise) (Figs 166-171) contain abundant material of Navicula seminulum as described by GRUNOw (1860, p. $552^{5}$, pl. 2, fig. 2a-d), i.e. a small species with a clear expansion in the central part of the valve ("medio plerumque leviter dilatata") and a wide and sub-rectangular central area (see Fig. 172). Later, VAN Heurck (1885, p. 106-107) classified N. seminulum in the Section 'Minutissimées', comprising "Navicules très petites, à structure difficilement visible" not forming band-shaped colonies. In this section VAN HEURCK 1.c. included three species with 'valves sans côtes' (without costae) and 'munie d'un pseudo-stauros' (with a 'pseudostauros'); these were:

- "Navicula seminulum GRUNOw, plate 14, fig. 9 - Type $\mathrm{N}^{\circ} 143 "$

- "Navicula minima GRUNow, plate 14, fig. 15 - Type $\mathrm{N}^{\circ} 142$ "

- "Navicula atomoides GRUNOw, plate 14, fig. 11 - Type $\mathrm{N}^{\circ} 219$ "

The main characteristics used to separate these three taxa were the presence or absence of a central inflation in the median portion (present in N. seminulum, absent in the other two) and the general shape of the valves ( \pm linear in $N$. seminulum and $N$. minima, elliptical in $N$. atomoides). Later authors also recognized Navicula seminulum as being "gibbous in the middle" (Cleve 1894, p. 128), "in der Mitte leicht aufgetrieben" (SCHÖNFELDT 1907, p. 46), or with "swollen effect in the central area" (PAtrick \& Reimer 1975, p. 489). Indeed Hustedt (1962, p. 242) recognized Navicula seminulum as: "Schalen schmal linear-elliptisch mit meistens leicht transapikal erweiterter Mitte und breit gerundeten Enden, in den kleinsten Individuen gewöhnlich völlig elliptisch bis fast kreisförmig"'. KRAMMER \& LANGE-BERTALOT (1986, p. 592, pl. 76, figs 37, 38) placed the species under the name Navicula joubaudii H. GERM., although clearly indicating " $a l s \mathrm{Na}$ vicula seminulum in V.H. Type de Synopsis 141".

Schoeman \& Archibald (1977) confused two species in their account of Navicula seminulum. The main reason is that the slide selected to illustrate $\mathrm{Na}$ -

\footnotetext{
$\left.{ }^{5}\right)$ Notice that there is a mistake in his figure captions from the original description (GRUNOw 1860, p. 552 refers to fig. 2 and not fig. 3. However, his plate legends are correct.

$\left.{ }^{6}\right)$ Free translation: "Very small Naviculae, with hardly visible structures".

$\left.{ }^{7}\right)$ Free translation: "Valves narrow linear-elliptical with transapically extended middle and broadly rounded ends, in the small cells individuals usually fully elliptic to almost circular."

$\left.{ }^{8}\right)$ The sample 'Type $n^{\circ} 141$ ' in Van Heurck (1885) used by KramMER \& LANGE-BERTALOT (1986) to illustrate Navicula joubaudii comes from Groenendael (Belgium). This sample most probably corresponds to Slide $\mathrm{n}^{\circ} 2599$ in the GrunOw collection (W), which is from the same locality and was observed and illustrated by SCHOEMAN \& ARCHIBALD (1977, fig. 20, under Navicula seminulum).
} 


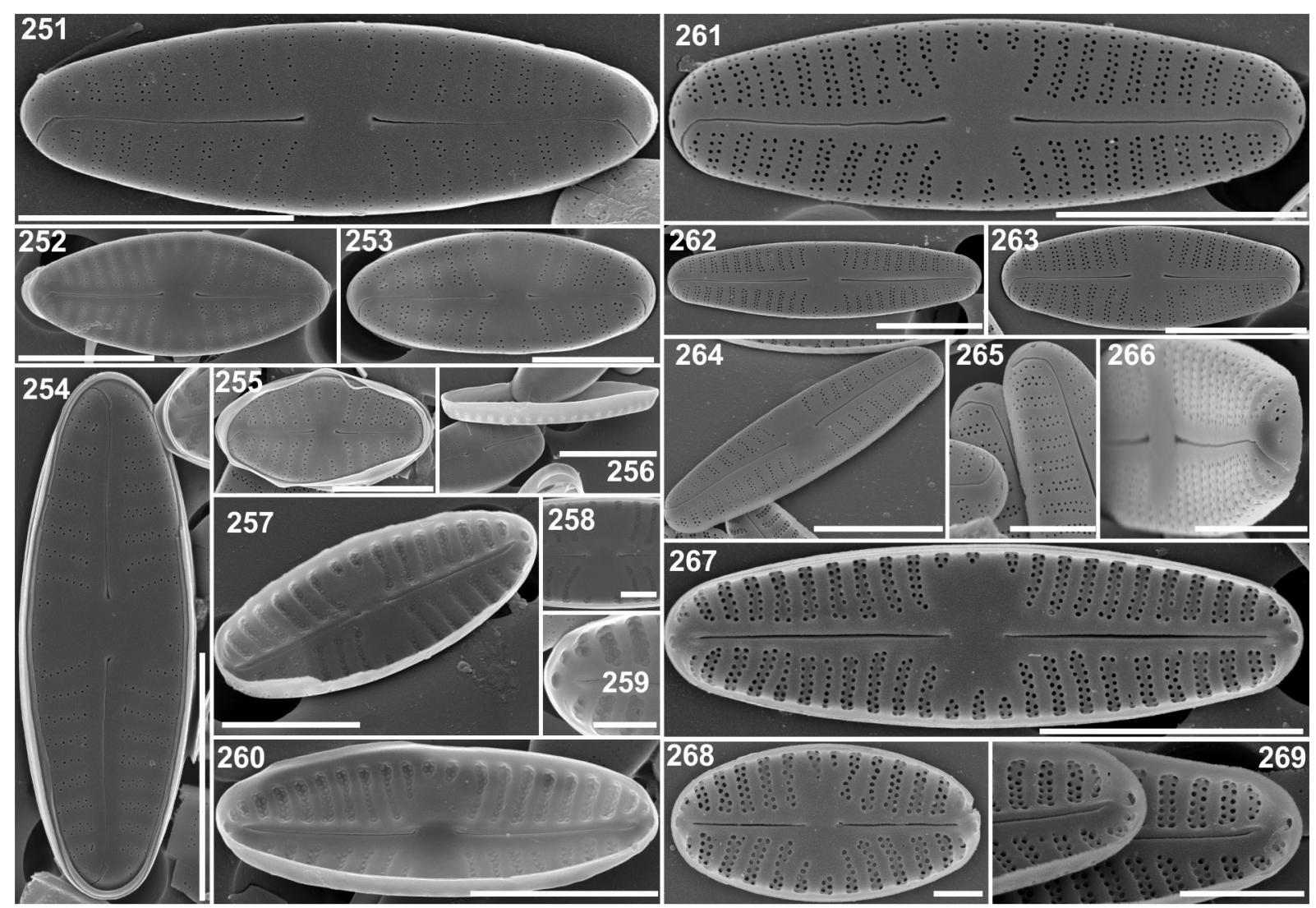

Figs 251-269. Sellaphora saugerresii comb. nov.: (251-260) SEM images of Navicula saugerresii DeSM. (1858), exsiccata $n^{\circ} 506$ in GRUNOW collection (W); (261-269) SEM images of Navicula minima Grunow in VAN Heurck (1880), sample 'Type ${ }^{\circ} 142$ ' in Van Heurck collection. Scale bars $5 \mu \mathrm{m}(251,254,261-264,267), 4 \mu \mathrm{m}(252,256,260), 3 \mu \mathrm{m}(253,255,257), 2 \mu \mathrm{m}(265,266,269), 1 \mu \mathrm{m}(258,259,268)$.

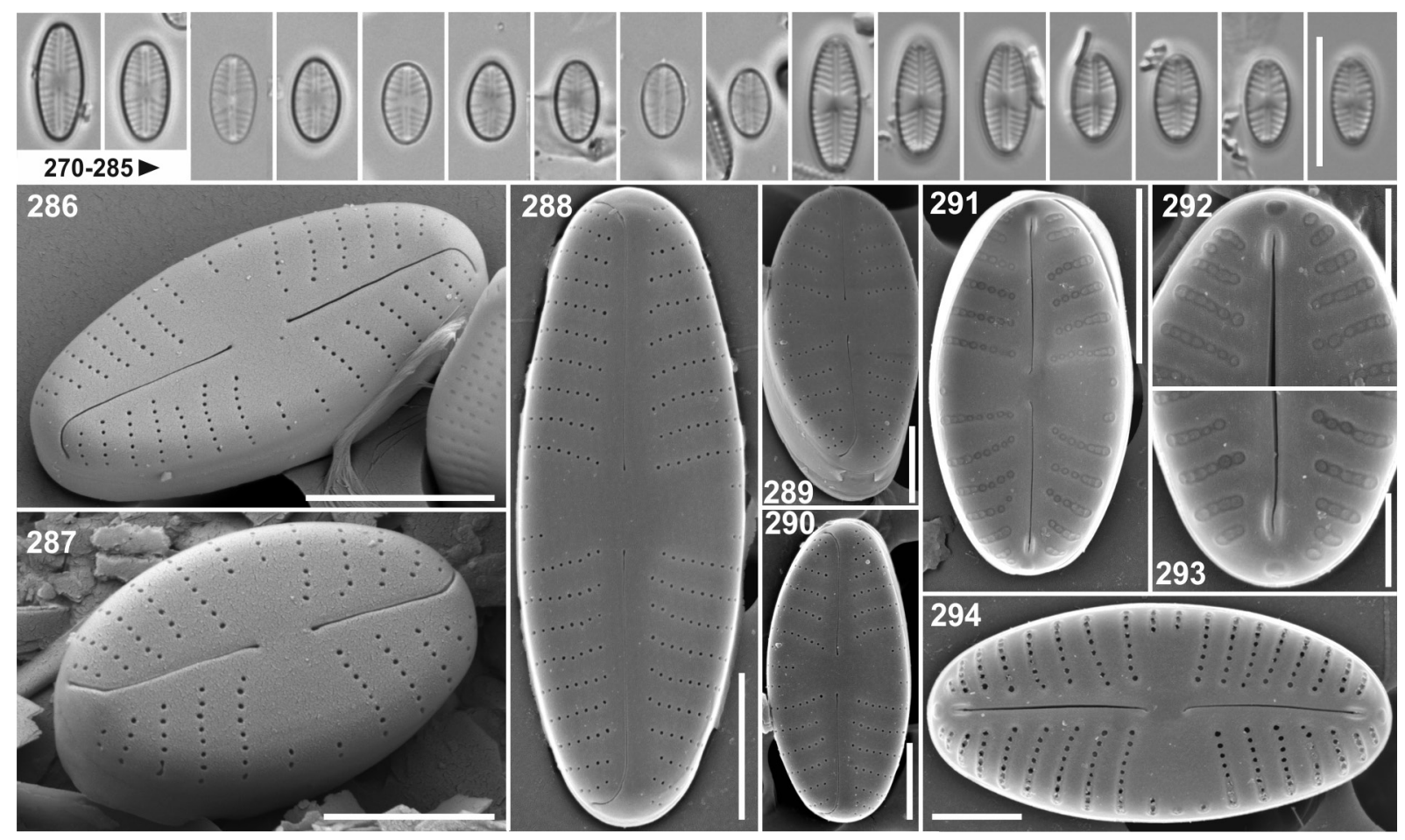

Figs 270-294. Sellaphora crassulexigua comb. nov. LM and SEM images of Navicula crassulexigua E. ReIchaRdt (1994): (270-286) Scie River at Saint-Maclou-de-Folleville, Normandy, France; (287) Bossea cave, SW Alps, NW Italy; (288-294) holotype n S668-T01, Steinerne Rinne, near Erasbach (Oberpfalz), Germany (REICHARDT collection). Scale bars $10 \mu \mathrm{m}(270-285), 5 \mu \mathrm{m}(288), 3 \mu \mathrm{m}(286,289,290), 2 \mu \mathrm{m}$ (287), $1 \mu \mathrm{m}(291-294)$ 
vicula minima was VAN HeURCK type $\mathrm{n}^{\circ} 142$ (Navicula minima) instead of type $\mathrm{n}^{\circ} 143$ (Navicula seminulum). SchoEMAN \& ARCHIBALD (1977) concluded that:

"In examining GRUNOW's material for Navicula minima GRUNOW it was found that VAN HEURCK's Types du Synopsis des Diatomées de Belgique $n^{\circ} 142$ (Vienna) marked as Navicula minima GRUN. var. is most certainly N. seminulum and cannot be considered as N. minima".

However, our observations of the samples 'Type $\mathrm{n}^{\circ} 143$ (Navicula seminulum)' and ' $\mathrm{n}$ ' 1580 (Navicula seminulum)', both authenticated by GRUNOw, reveal a species with a swollen central portion (Figs 158-171, 295, 297, 298, 299) that agrees well with his published drawing (Fig. 172). Indeed, Schoeman \& ARCHIBALD's (1977) illustrations of GrUNOw's slide $n^{\circ}$ 1580 from Vienna (their line drawings, figures 1 and 3) clearly show specimens with a swollen middle portion of the valve, agreeing with GRUNOw's original concept. Thus the only specimens illustrated by SCHOEMAN
\& ARChIBALD (1977) that agree with the descriptions of the species made by earlier authors [i.e. GRUNOw (1860), Van Heurck (1885), Cleve (1894), Hustedt (1930) and PAtrick \& Reimer (1975)] are their figures 1 and 3 (drawings from the slide 1580), figures 17 to 19 (slide 1580) and figure 20 (from Groenendael, Slide 2599). All other illustrated specimens correspond to Sellaphora saugerresii (Desm.) C.E. Wetzel et D.G. MAnN comb. nov. Comments concerning the confusion between $N$. seminulum and $N$. minima and the blurred history of these two species have already been made by WeBER \& McFARLAND (1981) and more recently by PotAPOVA (2013, p. 12).

Our observations of the type material of $N$. seminulum var. radiosa Hust. (sample E5926, from Eifel lake, Rheinland-Pfalz, Germany), which has also been illustrated by Simonsen (1987, pl. 595, figs 33-37), shows that this variety corresponds to the type material of Navicula seminulum GRUNOw in almost all morphological aspects. Although slightly narrower (Figs 173-
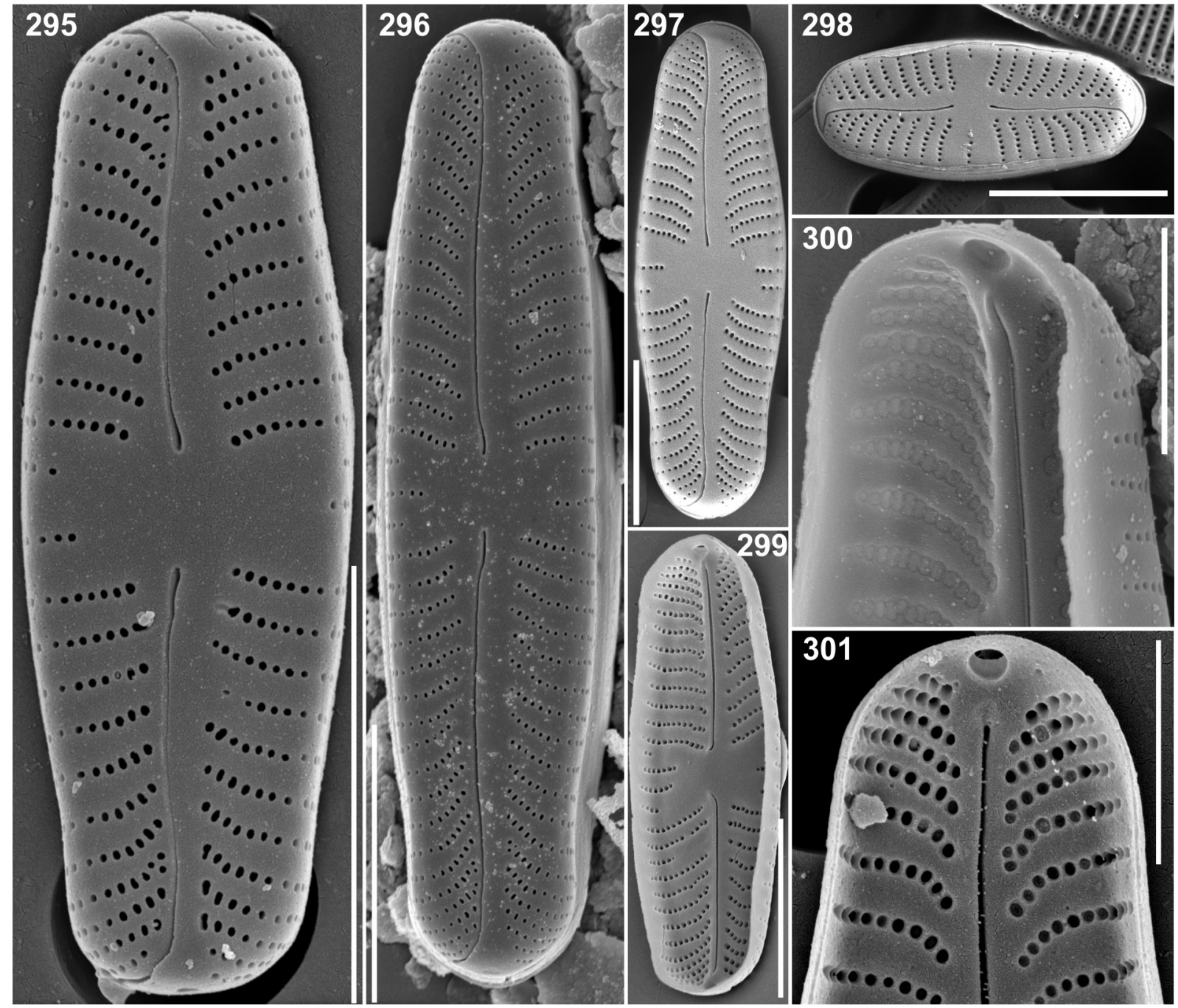

Figs 295-301. Sellaphora seminulum (Grunow) D.G. MAnN. SEM images: $(295,299,301)$ Navicula seminulum Grunow (1860), material ${ }^{\circ}$ 1580; (296, 300) Navicula seminulum var. radiosa Hust. (1954), sample E5926; (297, 298): Navicula seminulum Grunow in VAN HeURCK (1880), sample ‘Type $\mathrm{n}^{\circ}$ 143’ from VAN HeURCK collection (BR). Scale bars $5 \mu \mathrm{m}$ (295-299), $2 \mu \mathrm{m}$ (300, 301). 
179), Navicula seminulum var. radiosa Hust. (1954) shows no difference in ultrastructure or stria pattern and should be treated as a synonym of Navicula seminulum GRUNOw. Navicula seminulum var. radiosa was raised to species level and renamed as Navicula joubaudii H. Germ. by Germain (1982). Since then $\mathrm{Na}$ vicula seminulum GRUNOw has been treated mainly as Navicula joubaudii H. GERM. [= Sellaphora joubaudii (H. Germ.) Aboal in Aboal et al. 2003] in the literature.

Another variety of Navicula seminulum described earlier by Hustedt (1942) is $N$. seminulum var. intermedia Hust. Our analysis of the type material corroborates SIMONSEN's (1987, p. 302) suspicion that this taxon belongs to a monoraphid genus (Figs 302-307). This variety has already been placed as synonym of Achnanthes kryophila J.B. Petersen by Krammer \& Lange-Bertalot (1991, p. 30), which has recently been transferred to the genus Psammothidium by ReICHARDT (2004, p. 441, pl. 1, figs 1-9, pl. 2, figs 1-4), as Psammothidium kryophilum (J.B. Petersen) E. Reichardt ( $\equiv$ Achnanthes kryophila J.B. Petersen $1924 ;=N$. seminulum var. intermedia Hust. 1942; = Achnanthes plitvicensis Hust. 1945). The species discussed by LAVOIE et al. (2006) and illustrated by LAVOIE et al. (2008, p. 113) as Navicula cf. seminulum var. intermedia clearly belongs to the complex of species around Sellaphora nigri.

\section{Sellaphora subseminulum (Hust.) C.E. Wetzel comb. nov. (Figs 180-182)}

Basionym: Navicula subseminulum Hust. in BRENDEMÜHL 1949, Arch. Mikrobiol., vol. 14, p. 441, fig. 6.

Remarks: We provide illustrations of the same specimens studied by SiMONSEN (1987, p. 354, pl. 540, figs 10-12) from the type slide (N12/80, HustedT Collection at BRM, Bremerhaven). No material is available for SEM observations (Friedel Hinz, pers. comm.). KRAMMER \& LANGE-BERTALOT (1985, p. 74) synonymize the species with Navicula harderi Hust. because of their close morphological similarity and the occurrence of both in the type material of $N$. subseminulum. While observing samples from northern Bavaria ('Schwarzachklamm'), REICHARDT (2006, figs 36-40) pointed out that Navicula subseminulum is not synonymous with Navicula harderi and explained the differences between them, mainly concerning the higher stria density and the rhombic valve outline of the later species. REICHARDT (2006) recognizes $N$. subseminulum as having a wide central area that correspond to the material designated by Hustedt in BrendemüHL (1949). ReICHARDT 1.c. proposed the synonymization of Navicula subseminulum with Navicula obsoleta Hust. pro parte. However, Navicula obsoleta pro parte as illustrated by SiMONSEN (1987, p. 268) and REICHARDT (2006, figs 29-34), identified with a question mark as Navicula(dicta) obsoleta by REICHARDT is more similar to May-
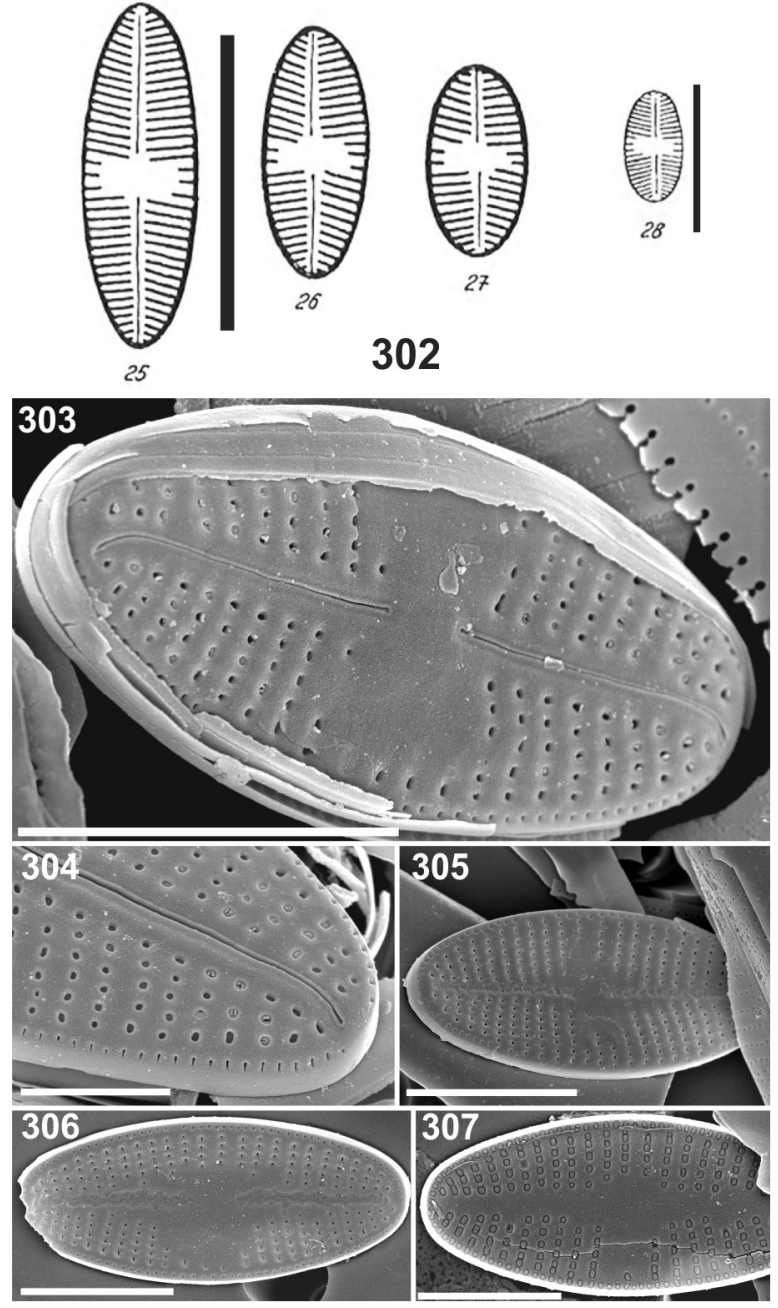

Figs 302-307. Psammothidium kryophilum (J.B. Petersen) E. ReICHARDT: (302) Original drawings of Syn: Navicula seminulum var. intermedia Hust. (1942, figs 25-28); (303-307) SEM images of sample E3808 from Abisko, Lappland (Sweden). Scale bars $10 \mu \mathrm{m}$ (302), $5 \mu \mathrm{m}$ (303, 305, 306), $4 \mu \mathrm{m}$ (307), $2 \mu \mathrm{m}$ (304).

amaea cavernicola VAN DE VIJVER et E.J. Cox (2013, p. 40, figs 21-40). Chamaepinnularia obsoleta (Hust.) C.E. Wetzel et Ector was recently defined by Wetzel et al. (2013, p. 158) and like S. subseminulum, occurs in aerial habitats in Europe (France and Luxembourg, WeTZEL, pers. obs.).

Sellaphora subseminulum was originally described from aerial habitats (beech forest soil at Göttingen, Germany: Brendemühl 1949), including samples of bare soil. Further literature records are also from aerial habitats or springs in Germany (SCHIMANSKI 1973; REICHARDT 1983, 1984, 2006). The species has rarely been found in freshwater ecosystems: our (non-exhaustive) search in the literature revealed only a few unconfirmed records (without illustrations) from U.S.A. Great Lakes (STOERmer et al. 1999) and New Zealand freshwater environments (COOPER 2001). We combine the species in Sellaphora based on the similarities with other Sellaphora species in LM, particularly $S$. saugerresii and S. atomoides. 

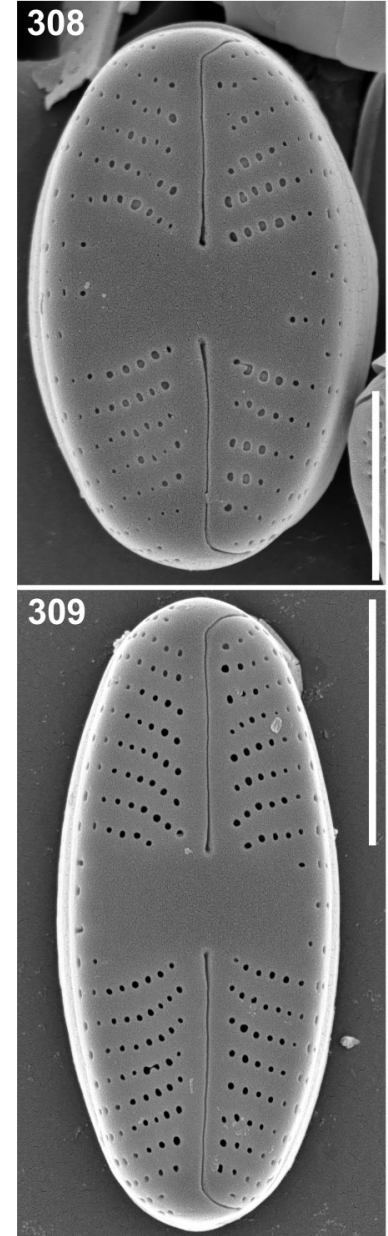
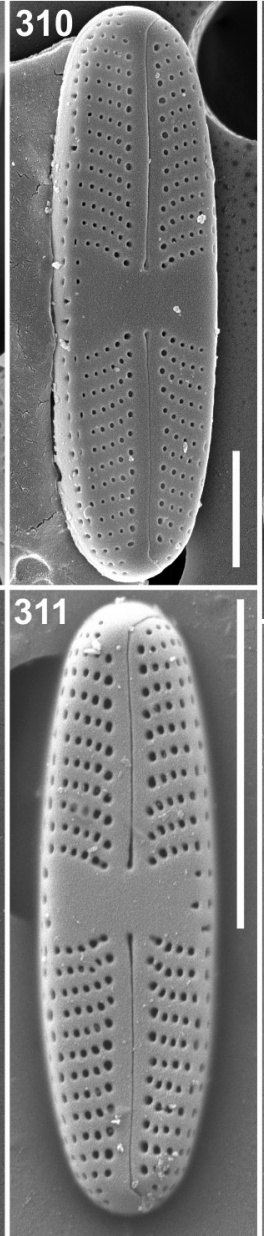
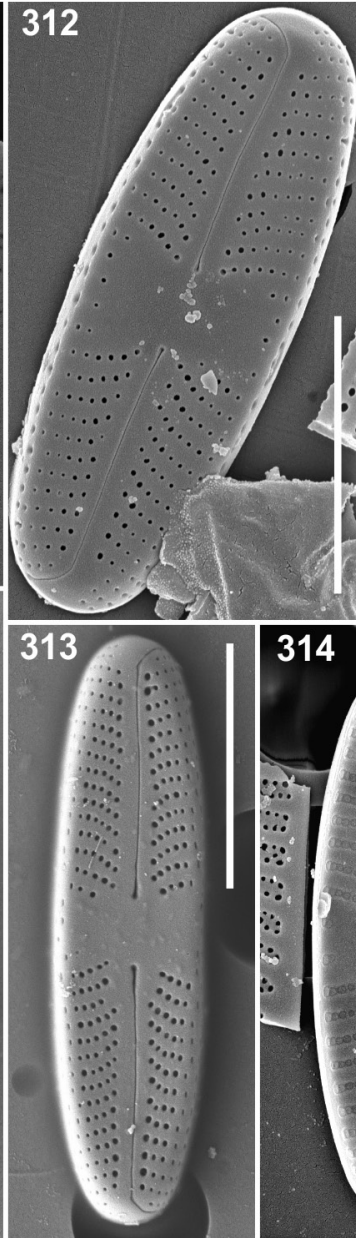
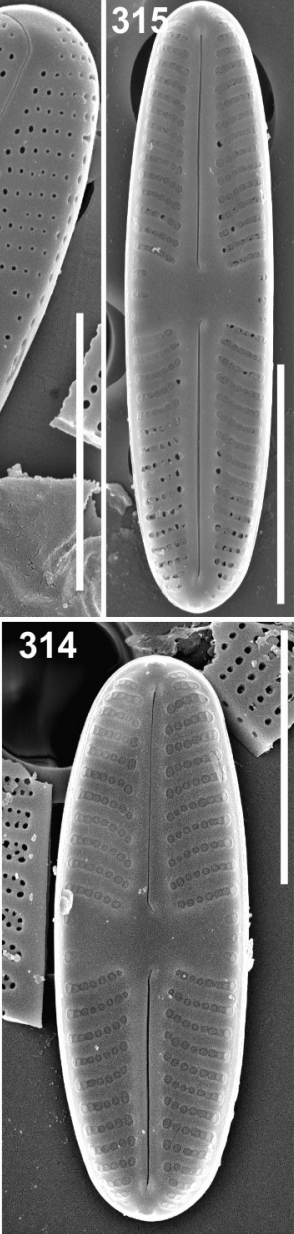
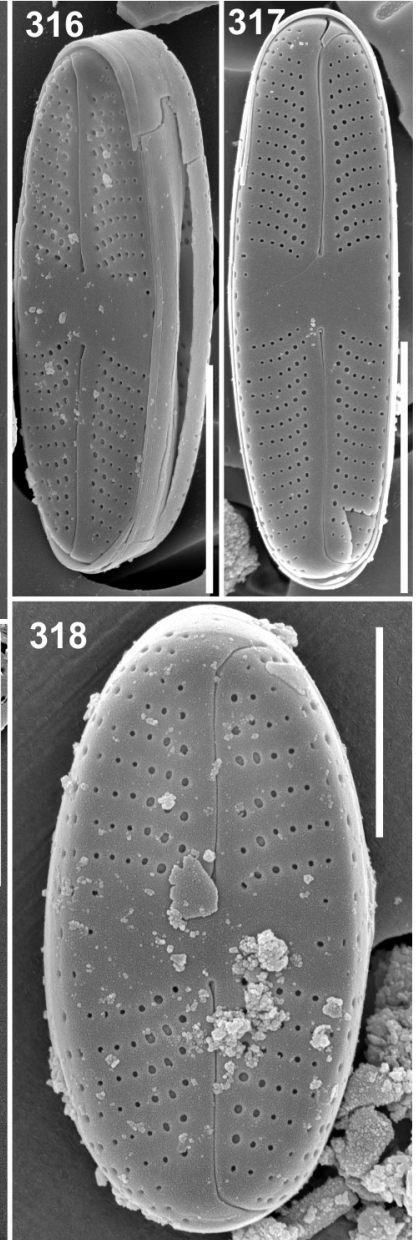

Figs 308-318. Sellaphora atomoides comb. nov. SEM images: (308-309) Navicula atomoides GrUNOw in VAN HeURCK (1880), sample “Type $\mathrm{n}^{\circ}$ 143" from Brussels, VAn Heurck collection (BR); (310-315) Navicula tantula Hust. (1934a, b), sample E869 from Poggenpohls Moor, Niedersachsen (Germany); (316-318) Stauroneis fonticola Hust. (1937), sample AS1321 from Tengger mountains (Java). Scale bars $5 \mu$ m $(310,311,313,315,317), 4 \mu \mathrm{m}(312,314,316), 3 \mu \mathrm{m}(309), 2 \mu \mathrm{m}(308,318)$.

Sellaphora atomoides (Grunow) C.E. Wetzel et VAN DE VIJVER comb. nov. (Figs 183-220, 308-318)

Basionym: Navicula atomoides Grunow in VAN Heurck 1880, Synopsis des Diatomées de Belgique, pl. 14, fig. 12 (Text: VAN Heurck 1885, p. 107).

Synonyms: $\equiv$ Navicula minima var. atomoides (GRUNOW in VAN Heurck) Cleve 1894, K. Svenska vetenskaps Akad. Handl. 26, p. 128; = Navicula tantula Hust. 1934, nomen nudum, Atlas der Diatomaceen-kunde, pl. 399, figs 54-57; = Navicula tantula Hust. 1934, nomen nudum, Abh. Vortr. Bremer Wissensch. Ges., vol. 8, p. 383; = Navicula tantula Hust. 1937, Arch. Hydrobiol. Suppl., vol. 15, p. 223; = Stauroneis fonticola Hust. 1937, Arch. Hydrobiol. Suppl., vol. 15, p. 223, pl. 15, figs 6, 7; = Navicula tantula Hust. 1943, Int. Rev. Ges. Hydrobiol. Hydrogr., vol. 43, p. 162; = Eolimna tantula (Hust.) Lange-Bert. in Werum \& Lange-Bertalot 2004, comb. invalid., Iconograph. Diatomol., vol. 13, p. 147, pl. 39, figs 8, 9, pl. 40, fig. 1; = Eolimna minima (Grunow) LANGe-Bert. pro parte sensu auct. nonnull in Moser et al. 1998, Biblioth. Diatomol., vol. 38, p. 153; = Eolimna krummensis P.M. Novis, J. Braidwood et C. KilroY 2012, Phytotaxa, vol. 64, p. 33, figs 112-129, 165.

Remarks: The VAN HEURCK "Type $\mathrm{n}^{\circ} 219$ " slide of Grunow's original material from the VAN HEURCK Collection in the Botanic Garden Meise (Figs 189-220) was observed but no corresponding material was available for SEM analysis. However specimens agreeing in all aspects (LM) with Navicula atomoides were also abundant in unmounted material of "Type $\mathrm{n}^{\circ} 143 \mathrm{Na}$ vicula seminulum" also observed by us, and it is from this material that the SEM images (Figs 308, 309) were taken. The observations reported below also concern the original material of Navicula tantula Hust. [= Eolimna tantula (Hust.) LANGE-Bert.] (Figs 183188, 310-315) and Stauroneis fonticola Hust. (Figs 221-235, 316-318). All these material contain small, elliptical to oval valves with broadly rounded apices, measuring 3.4-16.3 $\mu \mathrm{m}$ long and 2.6-3.7 $\mu \mathrm{m}$ wide, with 30-36 striae in $10 \mu \mathrm{m}$. The striae are uniseriate and radiate throughout. The striae bordering the central area are slightly but noticeably curved. Shorter striae, often with uneven lengths, are present in the middle of the valve and extend down onto a relatively shallow mantle. The axial area is linear through most of the valve, widening slightly near the central area. The central area is wide, symmetrical and bow-tie shaped. The raphe is straight with slightly inflated 'tear-drop' proximal ends, while the distal raphe fissures bend strongly to the same side of the valve (Figs 308-312). Interna- 

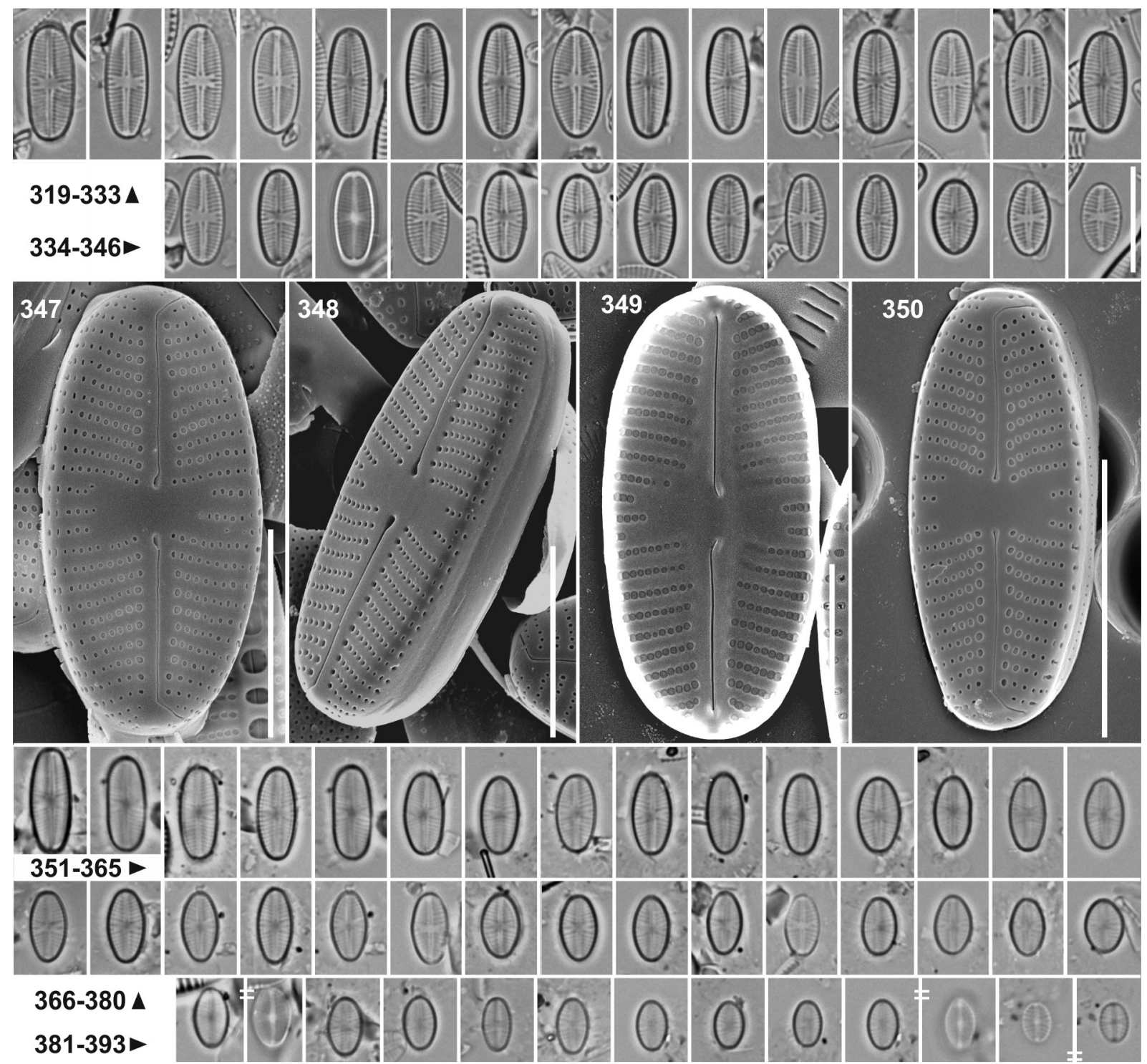

Figs 319-393. Sellaphora nigri comb. nov. emend.: (319-349) Neotype. BR-4396 (Botanic Garden Meise, BR, Belgium) LM (319-346) and SEM (347-349) images from Troine River (Tretterbaach) at Léresmillen (Luxembourg); SEM (350) and LM (351-393) images from a sample collected at the Veyle river at Vonnas (Rhône-Alpes Region, France). Scale bars $10 \mu \mathrm{m}(319-346,351,393), 5 \mu \mathrm{m}(350), 4 \mu \mathrm{m}(347,348), 3 \mu \mathrm{m}(349)$.

lly, the proximal raphe fissures are slightly deflected to the same side and the distal raphe fissures end in small helictoglossae (Figs 314, 315). The areolae vary in diameter and are closed internally with a hymen; the areolae closest to the raphe are sometimes larger in diameter. The girdle bands are plain, lacking areolae.

Navicula atomoides was described in VAN HEURCK (1885, p. 107) and previously illustrated by GRUNOW in VAN Heurck (1880, pl. 14, fig. 12). VAN Heurck slide "Type $\mathrm{n}^{\circ} 219$ " comes from a freshwater aquarium in Antwerp (Belgium). VAN HEURCK observed that cells of the species were usually united into groups of 3 or 4 and that they had a higher stria density than in $N$. minima and N. seminulum; a 'pseudo-stauros' is present in the central part of the cell. CLEVE (1894, p. 128) considered "atomoides" to be a variety of Navicula minima GRUNOw. HuSTEDT (1931, p. 272) seems at first to have followed the same species concept as CLEVE
(1894), considering Navicula atomoides as a variety of Navicula minima with denser striation. However, later (Hustedt 1962, p. 249), he listed Navicula atomoides as a synonym of Navicula minima GRUNOw and since then $N$. atomoides has been remained as such in widely used floras [i.e. PAtrick \& Reimer (1975, p. 488) and Krammer \& LANGe-Bertalot (1986, p. 229)]. In the meantime Hustedt (1934b, p. 383; 1943, p. 162) also referred (without a formal description or diagnosis) to a diatom he called Navicula tantula, which he had previously illustrated in the Atlas der Diatomaceenkunde (Hustedt 1934a, pl. 399, figs 54-57) from a peat bog from Oldenburg (Germany). In these references he did not mention $N$. atomoides as a similar species. In the same period HustedT (1937, p. 223) described Stauroneis fonticola, an aerophilic species from a spring in Java (Indonesia) differing from Navicula tantula by the presence of a stauroid form: “...sehr ähnlich der Navic- 
ula tantula Hust. A. S. Atl. T.399, F.54-57, deren Zentralarea aber nicht den Schalenrand erreicht und im Gegensatz zu Stauroneis fonticola keinen stauroiden Zentralknoten besitzt"9. This sentence can be considered as a diagnosis for Navicula tantula as indicated in SIMONSEN (1987, p. 172), whereas no diagnosis was given in the two previous publications where the name Navicula tantula was published (i.e. HustedT 1934a, b); hence, since a diagnosis or description has been a requirement for valid publication since 1908 (MCNEILL et al. 2012), 1937 should be considered as the year when $N$. tantula was validly described. A description of Navicula tantula also appears in 1943 (HuSTEDT 1943, p. 162): where HustEDT states “...Zentralarea eine breite, bis nahe an den Schalenrand reichende Querbinde, quadratisch bis rechteckig"10.

However, our observations of Navicula tantula and Stauroneis fonticola show no differences (either in LM or at the ultrastructure level using SEM: Figs 310 318) from specimens of Navicula atomoides in VAN Heurck Type $n^{\circ} 143$ (Figs 308, 309). Thus both species are treated by us as taxonomic synonyms of $\mathrm{Na}$ vicula atomoides. At about the same time as HustedT described $N$. tantula, $N$. minima var. typica R. Ross (1947, p. 194, pl. 9, fig. 5) was invalidly described as a new variety of $N$. mimina. We observed several slides mounted by Ross for his 1947 paper (slides BM35933, BM35934, BM35935, BM35957, BM35958) but no specimens corresponding to 'minima' or 'seminulum' could be found. Instead, we found 'monoraphid' species belonging to Psammothidium marginulatum (GRUNOw) Bukht. ET Round. [三 Achnanthes marginulata GRUNOw] (Figs 236-242) and Achnanthidium pusillum (Grunow) CZarn. [ $\equiv$ Achnanthes pusilla (Grunow) De TonI] (Figs 244-250).

Sellaphora nigri (De Not.) C.E. Wetzel et Ector comb. nov. emend. (Figs 319-393)

Basionym: Navicula nigri De Not. in De Notaris \& Baglietto, 1872, Nuovo Giorn. Bot. Ital., vol. 4, p. 296. Exsiccata. Ser. II, Fasc. XIII, $n^{\circ} 632$, p. 296, 1870, in Erbario Crittogamico Italiano, emend GranETti 1968d, Giorn. Bot. Ital., vol. 102, p. 428.

Synonym: - Eolimna minima (Grunow) LANGE-Bert. in Moser et al. 1998, Biblioth. Diatomol., vol. 38, p. 153, pro parte, sensu auct. nonnull.

Neotype (designated here): preparation BR-4396 (Botanic Garden Meise, BR, Belgium), collected at Troine River (Tretterbaach), Léresmillen (Luxembourg), 5005'15"N 556'41"E, leg. 23/08/2011. We chose the population from Luxembourg because the material observed by GRANETTI (1968d) is no longer available and thus a neotype is needed. Indeed, in his observations of DE NotARIS's original material of $N$.

\footnotetext{
$\left.{ }^{9}\right)$ Free translation: “...very similar to Navicula tantula Hust. A. S. Atl. T.399, F.54-57, concerning the central area, but this does not reach the edge of the shell and, in contrast to Stauroneis fonticola, no stauros-like central nodule is presents."

$\left.{ }^{10}\right)$ Free translation: "central area wide, reaching almost to the edge of the shell as a square to rectangular transverse fascia".
}

nigri, GRANETTI (1968d) observed that specimens were already very scarce ["Il materiale di studio (peraltro) estremamente scarso"].

Remarks: We identified a population from Luxembourg (Figs 319-349) corresponding to the species described as Navicula nigri by De NotARIS in De NoTARIS \& BAGLIETTO (1872). The species was originally collected by NEGRI in 1870, from submerged leaves of Nuphar lutea (L.) SM. in swamps along the Po River at 'Casale Monferrato' (Piedmont region in Italy). De NotARIs provided a detailed diagnosis including accompanying floristic elements ['Nitzschia amphibia var. padana', 'Amphora affinis' and 'Cyclotella kutzingiana' (= Cyclotella meneghiniana)] and comparison with similar species ("Ad Naviculam pelliculosam Hils. in Rabenh. Alg. n. 1265 accedit, sed noduli forma me judice distinguenda"). Almost a hundred years later GRANETTI (1968a, b, c, d), in his detailed series concerning the morphological variability of Navicula minima and Navicula seminulum, provided an appraisal of several species described by De NotARIs, including transmission electron microscope (TEM) images from the original material of Navicula nigri. GRANETTI (1968d) provided a size range for the original population of $\mathrm{Na}$ vicula nigri (i.e. length: 6.0-11.0 $\mu \mathrm{m}$; width: 3.8-4.7 $\mu \mathrm{m}$ ), and considered that it was identical to Navicula minima as described by GRUNOw in VAN HEURCK (1880). Hence, since Navicula minima was described eight years earlier than N. nigri, GraneTti (1968d, p. 428) proposed synonymization of these two species. However, the most similar species in this case is $\mathrm{Na}$ vicula atomoides, rather than Navicula minima sensu auct. nonnull. Thus synonymization of $N$. nigri with $N$. atomoides would be more logical, because both share several morphological characters and general valvar morphology. However, even if the general morphology of $N$. nigri is similar to $N$. atomoides (described above), the type material of Navicula atomoides (slide "Type $\left.n^{\circ} 219 "\right)$ in the VAN HeURCK collection shows a smaller species with narrower valves and generally denser striation ( $>$ ca. 34 striae in $10 \mu \mathrm{m}$, compared to ca. $25-28$ in $10 \mu \mathrm{m})$. Considering the morphometric measurements and the length-width ratios (Fig. 394, Hotelling's multivariate discriminant test $\mathrm{T}^{2} ; \mathrm{p}$ $<0.001$ ), we consider that there are significant differences between the two taxa and that they should be recognized as separate species.

Although the type materials of $S$. atomoides and $S$. nigri differ with respect to valve width, a second population identified by us as Navicula nigri from France was somewhat intermediate. This population was found during a routine analysis of diatom samples within the Water Framework Directive (WFD), and is illustrated here in Figs 350-393. While most of the visible characters in LM agreed with the type of $N$. nigri (including longer striae in the central area and the absence of a clear "bow-tie" central area), the specimens were rather smaller [width: $2.7-4.2 \mu \mathrm{m}$; mean width: 
$3.4 \mu \mathrm{m} ; n=56)$ when compared to the dimensions of $N$. nigri provided by GRANETTI (1968d), i.e. width of $3.8-4.7 \mu \mathrm{m}$ and when compared to mean width values $(4.0 \mu \mathrm{m} ; n=140)$ of the population from Luxembourg (Fig. 395). This fact and the finding of other populations outside the type locality, which provide a more comprehensive overview of its morphological variability, allow the proposal of an emended description of this species with a wider cell size range:

Description: Sellaphora nigri (De Not.) C.E. Wetzel et EcTOR comb. nov. emend. (Figs 319-393): Valves small, elliptical to oval, with broadly rounded apices. Valve dimensions $(n=190)$ : length $3.7-13.0 \mu \mathrm{m}$, width $2.7-4.8 \mu \mathrm{m}$. Striae uniseriate and radiate throughout the entire valve, $25-32$ in $10 \mu \mathrm{m}$; striae bordering the central area slightly curved. Shorter striae (usually 2 or 3 ), often with uneven lengths, are present in the very middle of the valve. Axial area linear over most of the valve, widening slightly near the central portion. Central area symmetrical but irregularly 'bow-tie' shaped to irregularly 'squared' and usually expanding to near the valve margin. Raphe straight with tear-drop proximal fissures and distal fissures that bend strongly to the same side of the valve. Internally, the proximal raphe fissures are slightly deflected to the same side and the distal raphe fissures ends as small helictoglossae. The areolae vary in diameter and shape. In the majority of specimens the areolae closest to the raphe are relatively larger and can be slightly angular, quadrate to nearly rounded, becoming smaller and more circular near the margins. In general the areolae closest to the raphe have slightly larger diameters. Areolae closed by vela; striae extending down onto a relatively shallow mantle. Junction of valve face and mantle sometimes not clearly defined. Girdle bands open and lacking areolae.

\section{Comments on the ecology and distribution of $S$. ato-} moides and $S$. nigri

A separation between Sellaphora atomoides [as Navicula (Eolimna) tantula] and Sellaphora nigri [as $\mathrm{Na}$ vicula (Eolimna) minima] has been supported by several authors. For example Germain (1981, pl. 85, figs 41-45) and Hofmann et al. (2011, pl. 42, figs 37-44) kept Sellaphora atomoides (as $N$. tantula) as a separate species with narrower frustules, denser striation and a more rectangular central area. The general acceptance is that S. atomoides (including E. tantula and Stauroneis fonticola) is usually found in aerial habitats (or more 'pristine' conditions) while the presence of Sellaphora nigri (as Eolimna minima sensu auct. nonnull.) is more related to human-impacted conditions of eutrophication, pesticides, heavy metal pollution and organically polluted environments (LANGE-BERTALOT \& BONIK 1976; Weber \& McFarland 1981; DAYNER \& JohanSen 1991; Delgado \& Pardo 2014; Morin et al. 2014; Moisset et al. 2015). Indeed the population from Lu- xembourg illustrated here (Figs 319-349) was accompanied by species characteristic of organically polluted waters such as Navicula subminuscula MANGUIN, Fistulifera saprophila (LANGE-BERT. et BONIK) LANGEBert., Mayamaea atomus (Kütz.) Lange-Bert., Navicula gregaria Donkin, Nitzschia palea (KüTz.) W. Smith and Nitzschia soratensis E. Morales et VIS. Sellaphora nigri is amongst the commonest benthic species in European freshwater courses and has until now been called Eolimna minima by the great majority of diatom analysts.

\section{Final remarks and conclusions}

The diatoms studied here are often abundant or even dominant in freshwater benthic communities. However, there have been many changes in species circumscription and concept since they were first described and the lack of analysis of original material has led to the propagation of many errors in taxonomy and identification. Some older, largely unused names have priority against well-known names, while other old names prove on examination to be unusable (at least without conservation). The confused history of these naviculoid taxa is of course partly because of their diminutive size and fine striation.

We propose to combine the studied species into Sellaphora mainly because several molecular studies have shown good support for a monophyletic group containing both "Eolimna minima" sensu auct. nonnull. and Sellaphora species, in which Sellapho$\mathrm{ra}$ would become paraphyletic if Eolimna is excluded from it (e.g. BehnKe et al. 2004; Bruder \& MedLin 2008; MAnN \& Evans 2007; Evans et al. 2008; MANN \& Stickle 2009; Rimet et al. 2011; Novis et al. 2012; Kociolek et al. 2013; ZGrundo et al. 2013; KuliKovSKIY et al. 2014; PoulíčKOvÁ et al. 2015; ZiMMERMANN et al. 2014, 2015).

A key feature of the genus Sellaphora is the shape of the chloroplast ('endochrome'); this is a single H-shaped plate and gives the genus its name (Sellaphora = 'saddle-bearer') (MEREsCHKOWsKy 1902, MANN et al. 2008). However, the chloroplast morphology has not been documented in most small naviculoid diatoms, including many of those studied here. Other morphological characteristics of Sellaphora, according to Round et al. (1990), include the following features: the cells are naviculoid and solitary, with uninterrupted uniseriate (rarely biseriate), radiate or parallel striae. Adjacent to the axial area there may be a nonporous conopeum. The valve face is flat, except that it is often grooved near the raphe externally, and curves fairly gently into shallow or moderately deep mantles. The striae contain small round poroids, which are occluded near their internal apertures by hymenes. Transapically orientated bar-like thickenings occur at the poles in some species (e.g. see MANN et al. 2008). The raphe system is central and straight. Terminal fissures are usually present, and may be deflected or hooked. The 


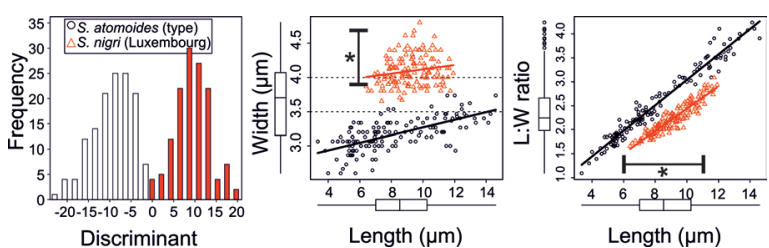

Fig. 394. Hotelling's multivariate discriminant test histogram, length, width and length:width ratio (L:W ratio) measurements of Sellaphora atomoides (slide "Type $\mathrm{n}^{\circ} 219$ ", $n=135$ ) and Sellaphora nigri [Troine River (Tretterbaach), Léresmillen, Luxembourg, $n=135] . *$ width and length ranges of Navicula nigri from the original material provided by GRANETTI (1968d) are indicated.
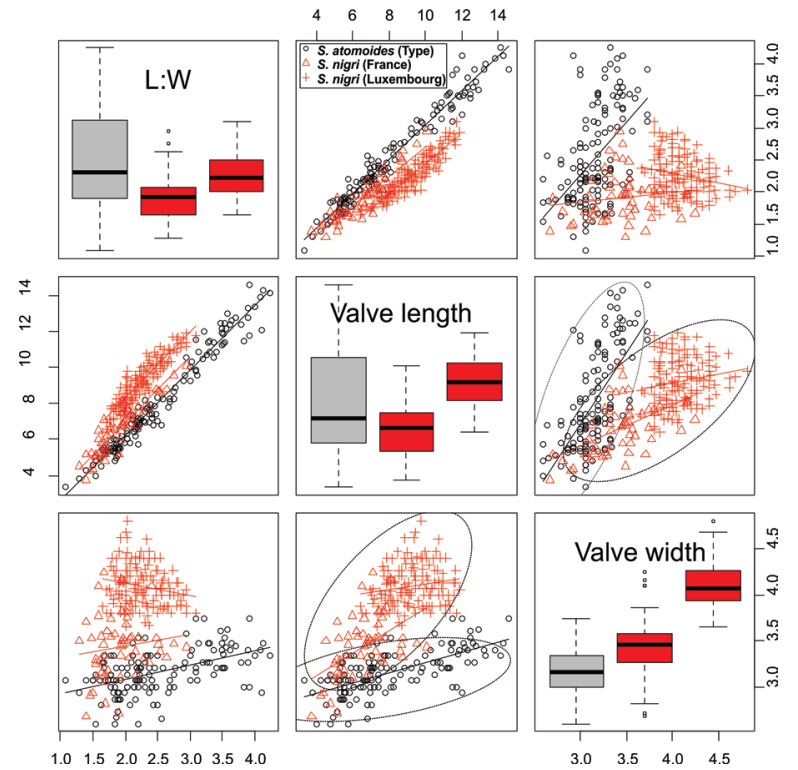

Fig. 395. Scatterplot matrix and boxplots of length, width and length:width ratio (L:W) measurements of Sellaphora atomoides (slide "Type $\mathrm{n}^{\circ} 219$ ", $n=135$ ) and Sellaphora nigri populations from Luxembourg $(n=135)$ and France $(n=56)$ illustrated in Fig. 15. Least-square lines and $95 \%$ confidence intervals are shown.

central external raphe endings are expanded and slightly deflected towards the primary side, and the central internal endings are also turned or deflected towards the primary side. In addition, we would add that the helictoglossae are often large and elongate in the largercelled species such as those illustrated by Round et al. (1990) and that many if not all species possess an internal apical pit at both poles. This seems to be common to all the species observed here, including the small species with biseriate striae like $S$. saugerresii, and it is also present in many larger-celled species, such as in the S. pupula, S. laevissima and S. bacillum groups (our unpublished observations). Detailed accounts of the genus are given by MANN (1989) and MANN et al. (2004, 2008 and 2009), while Mann \& Stickle (2009) have recently given a detailed account of the cytological characteristics of the family Sellaphoraceae. Allogamous sexual reproduction has been observed in about 30 species of Sellaphora, some belonging to the group of small-celled forms studied here, and in all cases it involves the production of a single gamete per gametangium and behavioural anisogamy, the gamete of the 'male' gametangium moving across into the 'female' gametangium to effect fertilization (MANN 1989, MANN et al. 1999, VANORMELINGEN et al. 2013). Hence a single auxospore is formed entirely within the 'female' gametangium. The auxospore then expands parallel to the apical axis of the female gametangium, with the empty male gametangium alongside. A modified type of auxosporulation occurs in several Sellaphora lineages, in which the auxospores are formed through paedogamy, but there is no doubt that the ancestors of these lineages exhibited allogamy of the typical kind described above (PoulíčKovÁ et al. 2015).

The genus Eolimna LAnge-Bert. et W. SCHILLER was established based on E. martini W. SCHILLER et LANGE-BERT., a freshwater fossil diatom species from the Lower Oligocene (SCHILLER \& LANGE-BerTALOT 1997). This species was described without light microscopy, making it difficult to make comparisons with other species, and of course, use of molecular phylogenetic data to explore the relationships of E. martini with living close relatives (if they still exist) is impossible. Nevertheless numerous taxa, originally described as Navicula, have been transferred to Eolimna (Moser et al. 1998; Werum \& Lange-Bertalot 2004; KuliKOVSKIY et al. 2010a), while several others have been described as new (e.g. Metzeltin \& Lange-Bertalot 1998, 2007; Coste \& Ector 2000; MonNier et al. 2003; Taylor \& Lange-Bertalot 2006; Blanco et al. 2009, Kopalová et al. 2009; KulikovskiY et al. 2012; KocioLEK et al. 2014). Eolimna was based on a combination of morphological features, but mainly on the positions of the hymenes in a median position, countersunk in the short areola canals (SCHILlER \& LANGE-BERTALOT 1997; Moser et al. 1998). However this character is variable in many species (e.g. Eolimna inconspicua GERD Moser et al., Eolimna thioense Gerd Moser et al., Eolimna rhombelliptica GERD MOSER et al., Eolimna zalokariae Metzeltin et LANGE-BERT., among others, see list below) and thus seems a doubtful taxonomic character. Moreover, some recently described species in Sellaphora show that the genus also comprises small species with 'Eolimna-like' characters, such as Sellaphora tumida VAn de ViJVer et Beyens, Sellaphora subantarctica VAN DE VIJVER et BEYENS in VAN DE VIJVER et al. (2002), Sellaphora hafnerae KAPETANOvić et R. JAHN, Sellaphora bosniaca KAPETANOviĆ et R. JAHN in KAPETANOVIĆ et al. (2011) and Sellaphora barae VAN DE VIJVER et E.J. Cox (2013).

In addition, some Eolimna- and Sellaphora-like species have been described in 'Naviculadicta' LANGEBERT., which was created (as an avowedly artificial group) by LANGE-Bertalot \& Moser (1994) to provide nomenclatural stability by provisionally removing those new species not fitting into Navicula sensu stricto or other clearly defined genera. However, this proposal has been criticized, either on principle (by KocIOLEK 


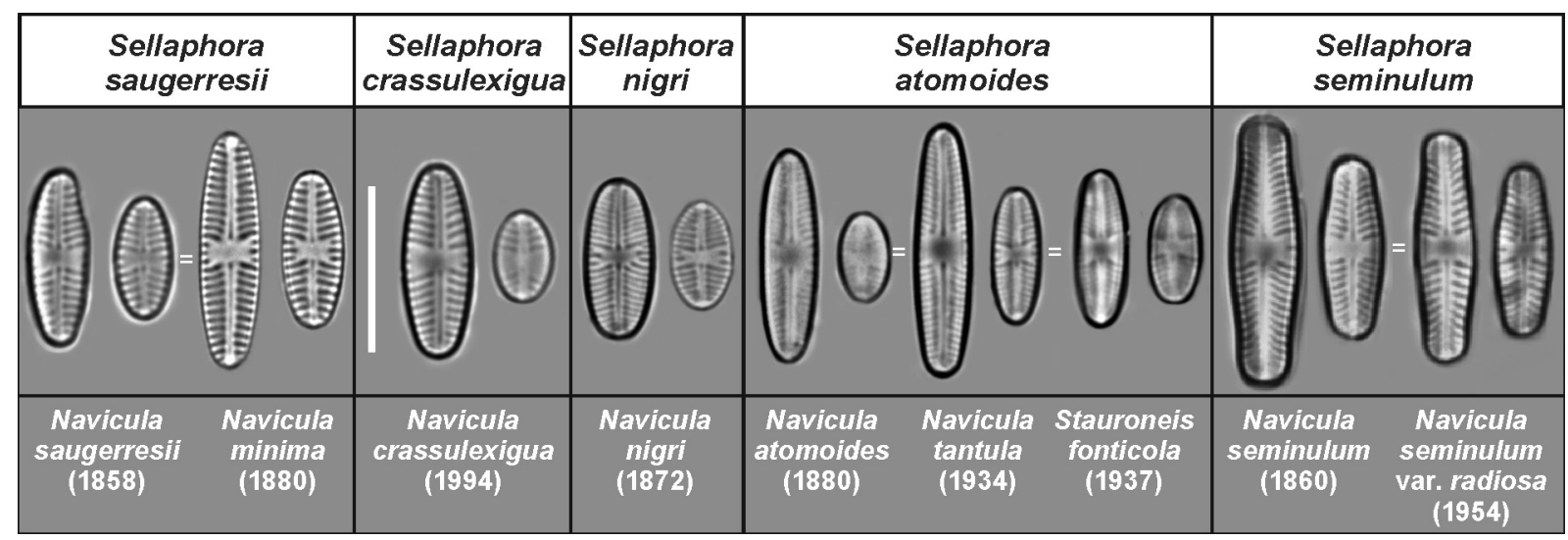

Fig. 396. Selected largest and smallest valves of five naviculoid taxa in LM. Images from original material, excepting Navicula nigri taken from a modern population [Troine River (Tretterbaach), Léresmillen, Luxembourg]. The five species are retained in the genus Sellaphora: $S$. saugerresii, S. crassulexigua, S. nigri, S. atomoides and S. seminulum. Synonyms (=) and date of publication of the basionyms are provided. Scale bar $10 \mu \mathrm{m}$.

1996) or with respect to its implementation (Round \& Mann 1996). The generitype of Naviculadicta is $\mathrm{Na}$ viculadicta vaucheriae (J.B. Petersen) Lange-Bert., a taxon that is represented by only very few specimens in the type slide (see Krammer \& LANGE-Bertalot 1986, pl. 76, figs 27-29) and whose type material is no longer available for SEM investigations (dixit KULIKOVSKIY et al. 2010b). The taxon is rarely mentioned in the literature (usually by hand-drawn illustrations) and its identity remains somewhat obscure. It cannot be placed in Sellaphora with any confidence. In contrast, many other species described in Naviculadicta [e.g. Naviculadicta elorantana LANGE-BERT., Naviculadicta multiconfusa LANGE-BERT., Naviculadicta pseudofusticulus LANGEBert. et Steindorf, Naviculadicta sassiana Metzeltin et LANGE-Bert., Naviculadicta vekhovii LANGE-BERT. et Genkal, among others described by F. Hustedt and illustrated by SIMONSEN (1987)] have been illustrated with LM or SEM images that contain enough information to allow their transfer to the genus Sellaphora. Potapova \& PonAder (2008) transferred Sellaphora wallacei (Reimer) Potapova et PonAder from Navicula and illustrated it with SEM; this species is very similar to Naviculadicta linearis Metzeltin et LANGE-BERTALOT (2002, p. 41, pl. 17, figs 9-10), which in turn is also very similar to Sellaphora rioplatensis METzELTIN, LANGE-BERT. et GARCÍA-RODRÍGUEZ from Uruguay (Metzeltin et al. 2005, p. 212, pl. 67, figs 13-27); this chain of similarities indicates that $N$. linearis is best transferred to Sellaphora. This is consistent with other recent transfers from Naviculadicta (or even Stauroneis), e.g. Sellaphora stauroneioides (LANGE-BERT.) Lange-Bert., Kulikovskiy et Witkowski, Sellaphora nana (Hust.) LANGE-Bert., CAVACINI, TAgliaventi et Alfinito (see StAneK-TARKowsKa et al. 2013; VAN DE VIJVER et al. 2013).

Some authors have attempted to find and apply criteria to separate Eolimna and Sellaphora. Thus, for example, EnAche \& Potapova (2009) justified keeping
Sellaphora pulchra ENACHE et POTAPOVA apart from Eolimna because the latter has fimbriae in the valvocopula and raphe on a raised sternum and that these features were not present in their specimens. However, the type species of Eolimna, E. martinii W.SCHILLER et LANGE-BERT. (described from Lower Oligocene sediments) does not have a raised sternum, and fimbriae are present in several Sellaphora species, e.g. S. gregoryana (our unpublished observations of a population from the type locality, Loch Leven, Scotland). Another character claimed to separate Eolimna from Sellapho$r a$, namely the presence of a row of areolae on the valvocopula in Eolimna but not in Sellaphora (SCHILLER \& LANGE-BERTALOT 1997), has been shown to vary within Sellaphora, even within a single species (MANN et al. 2011). Species with high stria density and small cells have tended to be placed apart from Sellaphora, which has often been reserved for morphologically similar species with large cells (see the diversity of the genus in the neotropics documented by Metzeltin \& LANGEBertalot 1998, 2007). However, closer examination of small-celled forms sometimes reveals characteristics that link them to 'typical' Sellaphora species. For example, the type materials of Navicula arvensis Hust. and Navicula difficilima Hust. both possess polar bars (pers. obs.), among other morphological features shared with Sellaphora, and thus are linked to the $S$. pupula and S. bacillum groups of species. We therefore transfer them into Sellaphora. Both are very similar to Sellaphora bosniaca KAPETANOvić et R. JAHN.

Overall, we can find no morphological characters that consistently separate Eolimna from $\mathrm{Se}$ llaphora or other naviculoid genera. To reinforce this conclusion we can point to other examples in the literature that indicate a continuum between Eolimna-like and Sellaphora-like forms. One is Sellaphora sardiniensis Lange-Bert., Cavacini, Tagliaventi et Alfinito (LANGE-Bertalot et al. 2003), which shows areola ultrastructures just like 'Eolimna' [e.g. Eolimna neo- 
caledonica (Manguin) Gerd Moser, Lange-Bert. et Metzeltin]. Another is illustrated by Metzeltin et al. (2005, pl. 65, figs 11-17), where they identified small specimens resembling Sellaphora atomoides (which includes what MetzeLtin et al. would have identified as Eolimna tantula) as Sellaphora aff. pseudopupula (Krasske) LANGE-BerT. It is possible, of course, that there is a cryptic separation of Eolimna and Sellaphora, just as there appears to be a cryptic separation between at least two groups of Nitzschia sect. Lanceolatae (e.g. Rimet et al. 2011; MANN et al. 2013). However, since the type species of Eolimna is a fossil more than $25 \mathrm{My}$ old, the chances are remote of being able to use molecular methods (or the occurrence of particular cytological or reproductive characteristics) to test possible separation between Eolimna and Sellaphora.

Navicula subminuscula ( $\equiv$ E. subminuscula) is transferred to Craticula here, since evidence has been found that this species has a quite different origin to the other species considered here. Including it in either Eolimna or Sellaphora would likely make these genera polyphyletic. For example, the molecular phylogenetic analysis by BRUDER \& MEDLIN (2008; see also ZGRUNDO et al. 2013 and ZIMMERMANN et al. 2014) indicates that E. subminuscula belongs in the family Stauroneidaceae, being sister to Craticula GRUNOw (BRUDER \& MEDLin 2008; ZimMERMANN et al. 2015); a distant relationship between $E$. subminuscula and 'E. minima' was also shown by BESZTERI et al. (2001).

In conclusion, there seems to be no clear differentiation between extant species of Eolimna, many Naviculadicta, and Sellaphora. Despite being described following a detailed morphological study (of the generitype, E. martinii: SchILlER \& LANGE-BerTALOT 1997), the genus Eolimna is distinguished mainly by a single morphological feature (i.e. the position of the areola coverings) that varies in other genera/species and as a consequence its validity has been strongly questioned (e.g. Morales \& Manoylov 2009). The endless discussion about generic limits and validity is related to the question of the value of each morphological feature and, in describing new genera, authors are not always consistent about this value, as recently pointed out by VAN DE VIJVER \& Cox (2015). Moreover, the interpretation of a genus is often too tightly limited to the characters seen in the generitype or in the original description, so that closely related species are sometimes separated unnecessarily into new genera, as observed by Cox (2009). We therefore propose the transfer of established taxa from either Navicula sensu lato, Eolimna or Naviculadicta LANGE-Bert. to Sellaphora, based on morphological and molecular evidence in published literature. However, confirmation from other data sources, such as chloroplast morphology, auxosporulation and gene sequences (MANN 1989; EvANs et al. 2008), is highly desirable for extant species.

Whatever the consensus adopted concerning generic boundaries, the most important issue, from the practical point of view, is the circumscription of individual species, since many of the species discussed are very common. Taking into account shape and size variation, stria density, and ultrastructure details, the following conclusions can be drawn:

- Synedra minutissima Kütz. [= Navicula minutissima (KÜTZ.) GRunOw 1860, nom. illeg.; = Navicula minima GRUNOw in VAN HeURCK 1880] does not correspond to the diatom many authors have called Navicula minima, following GRUNOw in VAN Heurck (1880) but is an amphoroid diatom; it is lectotypified and transferred to Halamphora.

- Navicula minutissima GRUNOw 1860, nom. illeg. (non RABENHORST) is a nomenclatural synonym of $N$. minima and both names have the same type, which is the type of Synedra minutissima KüTz.

- Navicula minutissima GRUNOw nom. inval. belongs to Sellaphora and is considered a synonym of the validly published species Sellaphora aggerica (E. ReICHARDT) FALASCO et EctOR (= Navicula aggerica E. REICHARDT).

- Sellaphora nigri comb. nov. (= Navicula nigri De Noт.) is a widely distributed species currently identified as 'Eolimna minima' in several modern floristic books and closely related to Sellaphora atomoides comb. nov. (= Navicula atomoides GRUNOw).

- Sellaphora atomoides should be recognized as a separate species, of which Eolimna tantula (= Navicula tantula) and Stauroneis fonticola are taxonomic synonyms.

- Sellaphora saugerresii comb. nov. (= Navicula saugerresii) and N. minima sensu auct., typo excl., should be considered as synonyms, the former having priority as the earliest available epithet; it should be transferred to Sellaphora.

- Sellaphora crassulexigua (= Navicula crassulexigua) should be recognized as a rarer separate species closely related to $N$. saugerresii.

- Sellaphora seminulum should be recognized as a separate species of which Navicula seminulum var. radiosa and Navicula joubaudii should be considered taxonomic synonyms.

The most common and problematic species (regarding the convoluted nomenclatural history and morphological similarities) are shown in the summary Figure 396, where five main names remain according to priority rules; proposed synonymies are also shown. Despite some evidence of phenotypic plasticity in the morphological characters used to separate diatom species, there seems no doubt that even the best morphology-based classifications will considerably underestimate species diversity, as already noted by MANN \& VANORMELINGEN (2013). Hence it is quite possible that each of the 'main names' refer to a species complex, rather than to single biological or phylogenetic species. 
Proposed new combinations on the genus Sellaphora

1. Sellaphora absoluta (HuST.) C.E. Wetzel, Ector, VAN DE ViJver, Compère et D.G. Mann comb. nov. Basionym: Navicula absoluta Hust. 1950, Arch. Hydrobiol., vol. 43 , p. 435 , pl. 38 , figs $80-85$.

2. Sellaphora ambiguissima (GERD Moser LANGeBert. et Metzeltin) C.E. Wetzel, Ector, Van de ViJver, Compère et D.G. Mann comb. nov.

Basionym: Naviculadicta ambiguissima GeRD MOSER, LANGE-BERT. et Metzeltin 1998, Biblioth. Diatomol., vol. 38, p. 202, pl. 20, figs $1-7$.

\section{Sellaphora arvensis (Hust.) C.E. Wetzel et} ECTOR comb. nov.

Basionym: Navicula arvensis Hust. 1937, Arch. Hydrobiol. Suppl., vol. 15 , p. 249, pl. 20, figs 19, 20.; $\equiv$ Navicula arvensis Hust. in SchMidT et al. 1936, nomen nudum, Atlas der Diatomaceen-kunde, pl. 401 , figs $22-26$.

\section{Sellaphora chilensis (KRASSKe) C.E. Wetzel} comb. nov., stat. nov.

Basionym: Navicula ruttneri var. chilensis KRASSKE 1939, Arch. Hydrobiol. Planktonk., vol. 35, p. 382, pl. 11, fig. 25.; झ Naviculadicta chilensis (KRASSKE) LANGE-Bert. in LANGE-Bertalot et al. 1996, Iconograph. Diatomol., vol. 3, p. 140.

5. Sellaphora chistiakovae (KULIKOVSKIY et LANGEBert.) C.E. Wetzel, Ector, VAN de ViJver, CompèRE et D.G. ManN comb. nov.

Basionym: Eolimna chistiakovae KuLIKOVSKIY et LANGE-Bert. in KulikovskiY et al. 2010, Diatom Res., vol. 25, p. 79, figs 1-18.

6. Sellaphora circumborealis (LANGE-Bert.) C.E. Wetzel, Ector, Van de ViJver, Compère et D.G. MANn comb. nov.

Basionym: Naviculadicta circumborealis LANGE-BERT. in LANGEBert. \& Moser 1994, Biblioth. Diatomol., vol. 29, p. 84-85, pl. 52, figs $29-36$

7. Sellaphora cosmopolitana (LANGE-BERT.) C.E. Wetzel et Ector comb. nov.

Basionym: Naviculadicta cosmopolitana LANGE-BERT. in RUMRICH et al. 2000, Iconograph. Diatomol., vol. 9, p. 177, pl. 77, figs 36-38.; 三 Navicula arvensis var. major LANGE-BERT. in KRAMMER \& LANGEBertalot 1985, Biblioth. Diatomol., vol. 9, p. 56, pl. 25, figs 1-3.

8. Sellaphora curta (Hust.) C.E. Wetzel, Ector, VAN de ViJver, Compère et D.G. Mann comb. nov. Basionym: Navicula curta Hust. 1937, Arch. Hydrobiol. Supp., vol. 15 , p. 272, pl. 20, figs 1-5.; 三Navicula curta Hust. in SCHMIDT et al. 1936, nomen nudum, pl. 401, figs 44-49.

9. Sellaphora damasii (Hust.) C.E. Wetzel, Ector, VAN de ViJVer, Compère et D.G. MANn comb. nov. Basionym: Navicula damasii Hust. in RABENHORST 1962, Kryptogamen Flora von Deutschland, Österreich und der Schweiz, Teil 3, Lief. 2, p. 203, fig. 1322.; = Navicula subcontenta var. africana Hust. 1949, Süsswasser-Diatomeen aus dem Albert-Nationalpark in Belgisch-Kongo, p. 85, pl. 4, figs 27, 28.

10. Sellaphora diahotana (LANGe-Bert. et STEINDORF) C.E. Wetzel, Ector, VAN de ViJver, Compère et D.G. ManN comb. nov.

Basionym: Naviculadicta diahotana (R. MAILlARD) LANGE-BERT. et STEINDORF in Moser et al. 1995, Biblioth. Diatomol., vol. 32, p. 130, pl. 56, figs 12-16.; 三 Navicula diahotana R. MAILlARD 1978, nom. inval., Cah. O.R.S.T.O.M., Sér. Hydrobiol., vol. 12, p. 154, pl. 1, fig. $6 a, b$.

11. Sellaphora difficillima (Hust.) C.E. Wetzel, Ector et D.G. Mann comb. nov.

Basionym: Navicula difficillima Hust. 1950, Arch. Hydrobiol., vol. 43, p. 436, pl. 38, figs 86-88.

12. Sellaphora digna (Hust.) C.E. Wetzel, Ector, Van de ViJVer, Compère et D.G. Mann comb. nov. Basionym: Navicula digna Hust. 1957, Abh. Naturwiss. Vereins Bremen., vol. 34, p. 270, figs 14, 15

13. Sellaphora elorantana (LANGE-Bert.) C.E. Wetzel comb. nov.

Basionym: Naviculadicta elorantana LANGE-BERT. in LANGEBertalot \& Metzeltin 1996, Iconograph. Diatomol., vol. 2, p. 84-85, pl. 28, figs 15-20, pl. 116, figs 3, 4.; 三 Eolimna elorantana (Lange-Bert.) Lange-Bert. et Kulikovskiy in Kulikovskiy et al. 2010, Diatom Res., vol. 25, p. 80, figs 19-36.

14. Sellaphora hentiensis (KuLIKovskiY, LANGEBert., Witkowski et Dorofeyuk) C.E. Wetzel et ECTOR comb. nov.

Basionym: Naviculadicta hentiensis KulIKovskiY, LANGe-Bert., WitKowski et DorofeYuk. in KulikovskiY et al. 2010, Biblioth. Diatomol., vol. 55, p. 44-45, pl. 44, figs 7-9.

15. Sellaphora inconspicua (GERD Moser, LANGEBert. et Metzeltin) C.E. Wetzel, Ector, Van de ViJver, Compère et D.G. Mann comb. nov.

Basionym: Eolimna inconspicua Gerd Moser, LANGE-Bert. et MetZELTIN 1998, Biblioth. Diatomol. vol. 38, p. 152, pl. 23, figs 1-5.

16. Sellaphora intermedia (Hust.) C.E. Wetzel, Ector, Van de ViJver, Compère et D.G. ManN comb. nov., stat. nov.

Basionym: Navicula bacillum f. intermedia Hust. 1942, Int. Rev. Gesamten Hydrobiol. Hydrogr., vol. 42, p. 64, fig. 120.; झ Navicula bacillum var. intermedia Hust. ex Simonsen 1987, Atlas and Catalogue of the Diatom Types of Friedrich Hustedt, p. 166, pl. 265, fig. $6 . ; \equiv$ Navicula bacillum var. intermedia Hust. in ScHMIDT et al. 1934, nomen nudum, pl. 396, fig. 45.

17. Sellaphora jamesrossensis (Kopalová et VAN DE ViJVer) VAN de ViJVer et C.E. Wetzel comb. nov. Basionym: Eolimna jamesrossensis Kopalová et VAN DE VIJVER in KopaLovÁ et al. 2009, Diatom Res., vol. 24, p. 116, figs 15-33.

18. Sellaphora javanica C.E. Wetzel stat. nov., nom. nov.

Replaced synonym: Navicula ruttneri var. capitata Hust. 1937, Arch. Hydrobiol. Suppl., vol. 15, p. 238, pl. 17, figs 24-26; $\equiv N a-$ vicula ruttneri var. capitata Hust. in SснмIDT et al. 1936, nomen nudum, pl. 402, figs 47-48.

19. Sellaphora jurafontinalis (LANGE-BERT. et Werum) C.E. Wetzel, Ector, Van de ViJVer, Compère et D.G. ManN comb. nov.

Basionym: Naviculadicta jurafontinalis Lange-Bert. et Werum in Werum \& Lange-Bertalot 2004, Iconograph. Diatomol., vol. 13, p. 166, pl. 35, figs 1-6; E Eolimna jurafontinalis (LANGE-BerT. et Werum) Lange-Bertalot et Kulikovskiy in Kulikovskiy et al. 2010, Diatom Res., vol. 25, p. 81

20. Sellaphora laticeps (Hust.) C.E. Wetzel, Ector, VAN DE ViJVer, Compère et D.G. ManN comb. nov. Basionym: Navicula laticeps Hust. 1942, Arch. Hydrobiol., vol. 39, p. 108 , figs $32-34$.

21. Sellaphora limata (Hust.) C.E. Wetzel, Ector, 
VAn de ViJver, Compère et D.G. Mann comb. nov. Basionym: Navicula limata Hust. 1944, Ber. Deutsch. Bot. Ges., vol. 61 , p. 274 , fig. 7 .

22. Sellaphora limatoides (Hust.) C.E. Wetzel, Ector, Van de ViJver, Compère et D.G. ManN comb. nov.

Basionym: Navicula limatoides Hust. 1950, Arch. Hydrobiol., vol. 43, p. 350, pl. 38, figs 33, 34 .

23. Sellaphora linearis (METzeLtin et LANGE-BERT.) C.E. Wetzel, Ector, VAN DE ViJVER, Compère et D.G. Mann comb. nov.

Basionym: Naviculadicta linearis Metzeltin et Lange-Bert. 2002, Iconograph. Diatomol., vol. 11, p. 41-42, pl. 17, figs 9, 10.

24. Sellaphora madida (Kociolek) C.E. Wetzel comb. nov.

Basionym: Eolimna madida Kociolek. in KocioleK et al. 2014, Bibliotheca Diatomologica, vol. 61, p. 25, pl. 28, figs 29-34; pl. 32, figs $1-4$.

25. Sellaphora manguinii C.E. Wetzel nom. nov. Replaced synonym: Navicula lepidula MANGUIN in BourRelly \& Manguin 1952, Algues d'eau douce de la Guadeloupe, p. 70, pl. 4, fig. 88a, b, non Navicula lepidula Grunow in VAN HeUrCK 1880; $\equiv$ Eolimna lepidula (Manguin) Metzeltin et Lange-Bert. 2007, Iconograph. Diatomol., vol. 18, p. 82, pl. 140, figs 28-30.

26. Sellaphora medioconvexa (HuST.) C.E. WETZEL comb. nov.

Basionym: Navicula medioconvexa Hust. in RABENHORST (ed.) 1961, Kryptogamen Flora von Deutschland, Österreich und der Schweiz, Teil 3, Seite 1-160, p. 151, fig. 1283.

27. Sellaphora mongolica (KulikovskiY, LANGEBert., Witkowski et Dorofeyuk) C.E. Wetzel et ECTOR comb. nov.

Basionym: Naviculadicta mongolica KulIKovSKIY, LANGE-BerT., Witkowski et Dorofeyuk in Kulikovskiy et al. 2010, Bibliotheca Diatomologica, vol. 55, p. 43-44, pl. 49, figs 36-41; pl. 55, figs 8,9.

28. Sellaphora moratoria (Gerd Moser, LANGeBert. et Metzeltin) C.E. Wetzel, Ector, Van de ViJver, Compère et D.G. ManN comb. nov.

Basionym: Naviculadicta moratoria Gerd Moser, Lange-Bert. et Metzeltin 1998, Biblioth. Diatomol., vol. 38, p. 204, pl. 22, figs 1-3.

29. Sellaphora multiconfusa (LANGE-BERT.) C.E. Wetzel, Ector, Van de ViJver, Compère et D.G. Mann comb. nov.

Basionym: Naviculadicta multiconfusa LANGE-BERT. in LANGE-BERTAlOT \& Moser 1994, Biblioth. Diatomol., vol. 29, p. 86-87, pl. 52, figs 39-43.

30. Sellaphora neocaledonica (MANGUIN ex KOCIOLEK et Reviers) C.E. Wetzel, Ector, Van de ViJver, ComPÈre et D.G. MANN comb. nov.

Basionym: Navicula neocaledonica MANGUin ex KocioleK \& ReVIERS 1996, Cryptog. Algol., vol. 17, p. 203.; = Navicula neocaledonica Manguin 1962, nomen nudum, Mém. Mus. Natl. Hist. Nat., B, Bot., vol. 12, p. 20, pl. 2, fig. 13.; झ Eolimna neocaledonica (MANguin) Gerd Moser, Lange-Bert. et Metzeltin 1998, Biblioth. Diatomol., vol. 38, p. 35, pl. 6, fig. 15, pl. 25, figs 1-5.

31. Sellaphora nympharum (Hust.) C.E. Wetzel, Ector, VAN de ViJver, Compère et D.G. Mann comb. nov.

Basionym: Navicula nympharum Hust. 1937, Arch. Hydrobiol. Su- ppl., vol. 15 , p. 247 , pl. 18 , figs 32,33 .

32. Sellaphora obdurata (M.H. HoHn et HELLERMAN) C.E. Wetzel, Ector, VAn de ViJver, Compère et D.G. Mann comb. nov.

Basionym: Navicula obdurata M.H. HoHn et Hellerman 1963, Trans. Amer. Microscop. Soc., vol. 82, p. 307, pl. 4, figs 27, 28.; $\equiv$ Naviculadicta obdurata (M.H. Hohn et Hellerman) LANGe-BerT. et Metzeltin 1996, Iconograph. Diatomol., vol. 2, p. 86, pl. 28, figs 11-14, pl. 118, figs 3-5.

33. Sellaphora paraffinis (LANGE-BERT. et STEINDORF) C.E. Wetzel, Ector, Van de ViJver, Compère et D.G. ManN comb. nov.

Basionym: Naviculadicta paraffinis LANGe-BERT. et SteIndorf in Moser et al. 1995, Biblioth. Diatomol., vol. 32, p. 131, pl. 55, figs 18-26; 三 Achnanthes pseudoaffinis R. MaILLARD 1978, nom. inval, Cah. O.R.S.T.O.M., Sér. Hydrobiol., vol. 12, p. 149, pl. 1, fig. 12a-c.

34. Sellaphora pseudoarvensis (HuST.) C.E. WETZEL et ECTOR comb. nov.

Basionym: Navicula pseudoarvensis Hust. 1942, Abh. Naturwiss. Vereins Bremen, vol. 32, p. 195, figs 8-10.

35. Sellaphora pseudofusticulus (GERD MOSER, Lange-Bert. et Metzeltin) C.E. Wetzel, Ector, Van de ViJver, Compère et D.G. Mann comb. nov. Basionym: Naviculadicta pseudofusticulus LANGE-BERT. et Steindorf in Gerd Moser, Lange-Bert. \& Metzeltin 1998, Biblioth. Diatomol., vol. 38, p. 205-206, pl. 21, figs 5-7.; झ Naviculadicta pseudofusticulus Lange-Bert. et Steindorf nomen nudum in Moser, Steindorf \& Lange-Bertalot 1995, Biblioth. Diatomol., vol. 32, p. 132, pl. 54, figs 14, 15 .

36. Sellaphora pseudoventralis (HUST.) C.E. WETZEL, Ector, VAN de VIJVER, COMPÈre et D.G. MANn comb. nov. Basionym: Navicula pseudoventralis Hust. 1953, Arch. Hydrobiol., vol. 47, p. 631, figs 12, 13; 三 Navicula pseudoventralis Hust. in Schмidт et al. 1936, nomen nudum, pl. 401, figs 116-118.

37. Sellaphora raederae (LANGE-BERT.) C.E. WETZEL comb. nov.

Basionym: Naviculadicta raederiae LANGE-BERT. in LANGE-BERTALOT \& Metzeltin 1996, Iconograph. Diatomol., vol. 2, p. 88, pl. 83, figs 37-40, pl. 116, figs 5, 6.; 三 Eolimna raederae (LANGE-BerT.) Lange-Bert. et Kulikovskiy in Kulikovskiy et al. 2010, Diatom Res., vol. 25, p. 81.

38. Sellaphora rhombelliptica (GERD MOSER, LANGEBert. et Metzeltin) C.E. Wetzel et Ector comb. nov. Basionym: Eolimna rhombelliptica Gerd Moser, LANGe-Bert. et Metzeltin 1998, Biblioth. Diatomol., vol. 38, p. 155, pl. 24, figs 1-9.

39. Sellaphora rionautensis (U. RUMRICH et LANGEBert.) C.E. Wetzel comb. nov.

Basionym: Naviculadicta rionautensis U. RUMRICH et LANGE-BERT. in Rumrich, Lange-Bertalot \& Rumrich 2000, Iconograph. Diatomol., vol. 9, p. 179-180, pl. 70, figs 14-18, pl. 79, fig. 8.

40. Sellaphora rotunda (HuST.) C.E. Wetzel, Ector, VAN de ViJVer, Compère et D.G. Mann comb. nov. Basionym: Navicula rotunda Hust. 1945, Arch. Hydrobiol., vol. 40, p. 916-917, pl. 41, fig. 29.; E Eolimna rotunda (Hust.) LANGE-BERT., KuLIKovskiY et WitKowski in KulikovskiY et al. 2010, Diatom Res., vol. 25, p. 81.

41. Sellaphora ruttneri (HuSt.) C.E. Wetzel comb. nov.

Basionym: Navicula ruttneri Hust. 1937, Arch. Hydrobiol. Suppl., vol. 15 , p. 238 , pl. 17 , figs $18-23 . ; \equiv$ Navicula ruttneri Hust. in SCHмiDT et al. 1936, nomen nudum, pl. 402, figs 49-52.; 三 Eolimna 
ruttneri (Hust.) Lange-Bert. et O. Monnier in Monnier, LangeBertalot \& Bertrand 2003, Bull. Soc. Sci. Nat. Ouest France, $2^{\text {ème }}$ Suppl. Hors Série, p. 140, figs 42-51; $\equiv$ Eolimna ruttneri (Hust.) Metzeltin et Lange-Bert. 2007, Iconograph. Diatomol., vol. 18, p. 82.

42. Sellaphora sassiana (Metzeltin et LAngeBert.) C.E. Wetzel comb. nov.

Basionym: Naviculadicta sassiana Metzeltin et LANGe-Bert. 1998, Iconograph. Diatomol., vol. 5, p. 144-145, pl. 75, figs 9-11.

43. Sellaphora schadei (KrassKe) C.E. Wetzel, Ector, VAN de ViJver, Compère et D.G. ManN comb. nov.

Basionym: Navicula schadei Krasske 1929, Bot. Arch., vol. 27, p. 355, fig. 11a-b.

44. Sellaphora schaumburgii (LANGE-BERT. et G. Hofmann) C.E. Wetzel et Ector comb. nov.

Basionym: Naviculadicta schaumburgii LANGE-BERT. et G. Hofmann in Werum \& Lange-Bertalot 2004, Iconograph. Diatomol., vol. 13, p. 167, pl. 36, figs 1-5; E Eolimna schaumburgii (LANGEBert. et G. Hofmann) Lange-Bert. et Kulikovskiy in Kulikovskiy et al. 2010, Diatom Res., vol. 25, p. 81.

45. Sellaphora schneckenburgeri (GERD MOSER, Lange-Bert. et Metzeltin) C.E. Wetzel, Ector, VAN DE ViJver, CoMpère et D.G. MANn comb. nov. Basionym: Naviculadicta schneckenburgeri GERD MOSER, LANGEBert. et Metzeltin 1998, Biblioth. Diatomol., vol. 38, p. 207, pl. 22, figs 7-11.

46. Sellaphora silvahercynia (LANGE-BERT.) C.E. WeTzel comb. nov.

Basionym: Navicula silvahercynia Lange-Bert. in LANGE-BertaLOT \& Krammer 1989, Biblioth. Diatomol., vol. 18, p. 164-165, pl. 56, figs 11-13, pl. 98, figs 45-50; 三 Eolimna silvahercynia (LANge-Bert.) Lange-Bert. in Werum \& Lange-Bertalot 2004, Iconograph. Diatomol., vol. 13, p. 147, pl. 27, figs 3-5.

47. Sellaphora simplex (HuSt.) C.E. Wetzel, Ector, VAn de ViJver, Compère et D.G. Mann comb. nov., stat. nov.

Basionym: Navicula ventralis var. simplex Hust. 1943, Int. Rev. Gesamten Hydrobiol. Hydrogr., vol. 43, p. 162, fig. 38; झ Navicula ventralis var. simplex Hust. in SснміDт et al. 1934, nomen nudum, pl. 400 , fig. 77 ; 三 Navicula ventralis f. simplex Hust. in RABENHORST (ed.) 1961, Kryptogamen Flora von Deutschland, Österreich und der Schweiz, Teil 3, Seite 1-160, p. 140, fig. 1273e; $\equiv$ Navicula ventraloconfusa f. simplex (Hust.) LANGe-Bert. in LANGE-Bertalot \& Krammer 1989, comb. inval., Bibliotheca Diatomol., vol. 18, p. 166.

48. Sellaphora sorella (M.H. HoHn et Hellerman) C.E. Wetzel, Ector, Van de ViJver, Compère et D.G. Mann comb. nov.

Basionym: Navicula sorella M.H. Hohn et Hellerman 1963, Trans. Amer. Microscop. Soc., vol. 82, p. 311, pl. 4, fig. 23.

49. Sellaphora subarvensis (Hust.) C.E. Wetzel, Ector, Van de ViJver, Compère et D.G. ManN comb. nov.

Basionym: Navicula subarvensis Hust. 1942, Int. Rev. Gesamten Hydrobiol. Hydrogr., vol. 42, p. 60, figs 107, 108.

50. Sellaphora subcontenta (Hust.) C.E. Wetzel, Ector, Van de ViJver, Compère et D.G. ManN comb. nov.

Basionym: Navicula subcontenta Hust. 1942, Int. Rev. Gesamten Hydrobiol. Hydrogr., vol. 42, p. 58-59, fig. 105.
51. Sellaphora submuralis (HuSt.) C.E. Wetzel, Ector, Van de ViJver, Compère et D.G. ManN comb. nov.

Basionym: Navicula submuralis Hust. 1945, Arch. Hydrobiol., vol. 40, p. 918, pl. 41, fig. 37.; 三 Eolimna submuralis (Hust.) LANGEBert. et KulikovskiY in Kulikovskiy et al. 2010, Diatom Res., vol. 25 , p. 81 .

52. Sellaphora subnympharum (HuST. ex SimonSEN) C.E. Wetzel, Ector, Van de ViJver, Compère et D.G. Mann comb. nov.

Basionym: Navicula subnympharum Hust. ex Simonsen 1987, Atlas and Catalogue of the Diatom Types of Friederich Hustedt, p. 189, pl. 301, figs 7-12; $\equiv$ Navicula subnympharum Hust. in ScHMidT et al. 1936, nomen nudum, pl. 401, figs 88, 89 .

53. Sellaphora subrotundata (Hust.) C.E. WETzEL, Ector, Van de ViJVer, Compère et D.G. Mann comb. nov.

Basionym: Navicula subrotundata Hust. 1945, Arch. Hydrobiol., vol. 40, p. 917, pl. 41, figs 30-33.

54. Sellaphora tenellaeformis (HuSt.) C.E. WETzel, Ector, Van de ViJVer, Compère et D.G. ManN comb. nov.

Basionym: Navicula tenellaeformis Hust. 1937, Arch. Hydrobiol. Suppl., vol. 15, p. 269, pl. 19, figs 14, 15.

55. Sellaphora thienemannii (Hust.) C.E. Wetzes, Ector, Van de ViJver, Compère et D.G. Mann comb. nov.

Basionym: Navicula thienemannii Hust. 1937, Arch. Hydrobiol. Suppl., vol. 15, p. 235-236, pl. 17, figs 16, 17.

56. Sellaphora tignaria (Hust.) C.E. Wetzel, ECTOR, VAN DE ViJVER, Compère et D.G. MANn comb. nov. Basionym: Navicula tignaria Hust. 1942, Int. Rev. Gesamten Hydrobiol. Hydrogr., vol. 42, p. 59, figs 103, 104.

57. Sellaphora tridentula (KRASSKe) C.E. Wetzel comb. nov.

Basionym: Navicula tridentula KrassKe 1923, Bot. Arch., vol. 3, p. 198, fig. 1.

58. Sellaphora thioense (Gerd Moser, LangeBert. et Metzeltin) C.E. Wetzel, Ector, Van de ViJver, Compère et D.G. MANn comb. nov.

Basionym: Eolimna thioense Gerd Moser, LANGe-Bert. et MetzeLTIN 1998, Biblioth. Diatomol., vol. 38, p. 157, pl. 23, figs 6-10.

59. Sellaphora utermoehlii (Hust.) C.E. Wetzel et D.G. Mann comb. nov.

Basionym: Navicula utermoehlii Hust. 1942, Int. Rev. Gesamten Hydrobiol. Hydrogr., vol. 42, p. 62; 三 Navicula utermoehlii Hust. in SchмiDT et al. 1936, nomen nudum, pl. 404, figs 31, 32; 三 Eolimna utermoehlii (Hust.) Lange-Bert., Kulikovskiy et WitKowski in KuLIKovskiY et al. 2010, Diatom Res., vol. 25, p. 81.

60. Sellaphora vanlandinghamii (KoCIOLEK) C.E. WeTzel comb. nov.

Basionym: Eolimna vanlandinghamii KocioleK in KocioleK et al. 2014, Bibliotheca Diatomologica, vol. 61, p. 24, pl. 28, figs 21-28; pl. 31, figs 5-8.

61. Sellaphora vekhovii (LANGE-BERT. et GENKAL) C.E. Wetzel et D.G. Mann comb. nov.

Basionym: Naviculadicta vekhovii LANGE-Bert. et GeNKAL 1999, Iconograph. Diatomol., vol. 6, p. 74-75, pl. 20, figs 20, 21; 三 Eolimna vekhovii (Lange-Bert. et GenKal) Lange-Bert. et KulikovskiY in KuLIKovskiY et al. 2010, Diatom Res., vol. 25, p. 81. 
62. Sellaphora ventralochilensis C.E. WETzEL et ECTOR stat. nov., nom. nov.

Replaced synonym: Navicula ventralis var. chilensis KRASSKE 1939 , Arch. Hydrobiol. Planktonk., vol. 35, p. 383, pl. 11, fig. 45.; = Naviculadicta ventraloconfusa var. chilensis (KRASSKE) LANGE-BERT. in LANGe-Bertalot et al. 1996, Iconograph. Diatomol., vol. 3, p. 155, pl. 18, figs 12-14.

63. Sellaphora verecunda (Hust.) C.E. Wetzel, Ector, VAN de ViJVer, Compère et D.G. ManN comb. nov.

Basionym: Navicula verecunda Hust. in PASChER 1930, Die Süsswasser-Flora Mitteleuropas, Heft 10, p. 302, fig. 522.

\section{Sellaphora verecundaeformis (Manguin ex Ko-} Ciolek et Reviers) C.E. Wetzel comb. nov.

Basionym: Navicula verecundaeformis MANGUIN ex KocIOLEK \&REVIERs 1996, Cryptog., Algol., vol. 17, p. 204-205; 三Navicula verecundaeformis Manguin 1962, Mém. Mus. Natl. Hist. Nat., B, Bot., vol. 12, p. 22, pl. 2, fig. 21a, b, nom. invalid.; E Eolimna verecundaeformis (MAnguin) Gerd Moser, Lange-Bert. et Metzeltin 1998, comb. invalid., Biblioth. Diatomol., vol. 38, p. 35, pl. 6, figs 28-34.

\section{Craticula subminuscula (MANGUIN) C.E. WETZEL et ECTOR comb. nov.}

Basionym: Navicula subminuscula MANGUIN 1942, Travaux Algologiques, Sér. 1., vol. 2., p. 139, pl. 2, fig. 39; 三Eolimna subminuscula (Manguin) Gerd Moser, Lange-Bert. et Metzeltin 1998, Biblioth. Diatomol., vol. 38, p. 154.

\section{ACKNOWLedgements}

Funding for this research was provided by the Luxembourg National Research Fund (FNR) in the framework of the BIGSTREAM (C09/ SR/14), ECSTREAM (C12/SR/40/8854) and TAXODIA project (LIST-Luxembourg Institute of Science and Technology). We are grateful for support from SYNTHESYS (financed by European Community Research Infrastructure Action under FP6 and 7) for a research visit of David Mann to the Naturhistorisches Museum, Vienna; Anton Igersheim, for generous help in the use of the Grunow Collection and for loans of material; Erwin Reichardt, Friedel Hinz and Jovita Yesilyurt for arranging loans of type material; Frédéric Pétel (DREAL Haute-Normandie, France), Rémy Chavaux (DREAL Rhône-Alpes, France) and Elisa Falasco (University of Torino, Italy) are thanked as well.

\section{REFERENCES}

Abarca, N.; Jahn, R.; Zimmermann, J. \& EnKe, N. (2014): Does the cosmopolitan diatom Gomphonema parvulum (Kützing) Kützing have a biogeography? - PLoS ONE 9: e86885.

Aboal, M.; Alvarez-Cobelas, M.; Cambra, J. \& Ector, L. (2003): Floristic list of non marine diatoms (Bacillariophyceae) of Iberian Peninsula, Balearic Islands, and Canary Islands. Updated taxonomy and bibliography. - In: Witkowski, A. (ed.): Diatom Monographs, vol. 4. - 639 pp., A.R.G. Gantner Verlag, Ruggell, Liechtenstein.

Behnke, A.; Friedl, T.; Chepurnov, V.A. \& Mann, D.G. (2004): Reproductive compatibility and rDNA sequence analysis in the Sellaphora pupula species complex. - J. Phycol. 40: 193-208.

Beszteri, B.; Ács, E.; MakK, J.; KovÁcs, G.; Márialideti, K. \& Kiss, K.T. (2001): Phylogeny of six naviculoid diatoms based on $18 \mathrm{~S}$ rDNA sequences. - Int. J. Syst.
Evol. Microbiol. 51: 1581-1586.

Blanco, S.; Novais, M.H.; Hoffmann, L. \& Ector, L. (2009): Eolimna becaresii sp. nov., a new diatom taxon from a Spanish shallow lake. - Diatom Res. 24: 487-494.

BRENDEMÜHL, I. (1949): Über die Verbreitung der Erddiatomeen. - Arch. Mikrobiol. 14: 407-449.

Bruder, K. \& Medlin, L.K. (2008): Morphological and molecular investigations of Naviculoid diatoms II. Selected genera and families. - Diatom Res. 23: 283-329.

Cleve, P.T. (1894): Synopsis of the naviculoid diatoms, Part I. - K. Svenska vetenskaps. Akad. Handl. 26: 1-194.

Cooper, V.C. (2001): Recent name changes in eukaryotic freshwater algae of New Zealand - New Zealand J. Bot. 39: 601-616.

Coste, M. \& Ector, L. (2000): Diatomées invasives exotiques ou rares en France: principales observations effectuées au cours des dernières décennies. - Syst. Geogr. Plants 70: 373-400.

Coste, M. \& Ricard, M. (1990): Les diatomées des eaux douces des îles de Tahiti et Moorea (archipel de la Société, Polynésie française). - In: Ricard, M. (ed.): Ouvrage dédié à la Mémoire du Professeur Henry Germain (1903-1989) - pp. 33-62, Koeltz Scientific Books, Königstein.

Cox, E.J. (2009): What's in a name? - Diatom classification should reflect systematic relationships. - Acta Bot. Croat. 68: 443-454.

DaYner, D.M. \& Johansen, J.R. (1991): Observations on the algal flora of Seneca Cavern, Seneca County, Ohio. Ohio J. Sci. 91: 118-121.

Delgado, C. \& Pardo, I. (2014): Comparison of benthic diatoms from Mediterranean and Atlantic Spanish streams: Community changes in relation to environmental factors. - Aquat. Bot. 120: 304-314.

DesmaziÈRES, J.B.H.T. (1858): Navicula saugerri Desmazières. - Plantes cryptogames de France. Ed. 2(2), fasc. $11-12, \mathrm{n}^{\circ} 506$.

De Notaris, G.E. \& Baglietto, F. (1872): Erbario crittogamico italiano. Serie II. Fascicolo XIII. Genova, Giugno 1872. - Nuovo Giorn. Bot. Ital. 4: 296-297.

De Toni, G.B. (1892): Sylloge algarum omnium hucusque cognitarum. Vol. II. Bacillarieae. Sectio II. Pseudoraphideae. - Typis Seminarrii, Patavii. pp. 491-817.

Enache, M.D. \& Potapova, M. (2009): A new species of Sellaphora (Sellaphoraceae) from Hannaberry Lake, Arkansas, U.S.A. - Acta Bot. Croat. 68: 231-237.

Evans, K.M.; Wortley, A.H.; Simpson, G.E.; Chepurnov, V.A. \& MANN, D.G. (2008): A molecular and systematic approach to explore diversity within the Sellaphora pupula species complex (Bacillariophyta). - J. Phycol. 44: 215-231.

Falasco, E.; Blanco, S.; Bona, F.; Gomà, J.; Hlúbiková, D.; Novais, M.H.; Hoffmann, L. \& Ector, L. (2009): Taxonomy, morphology and distribution of the Sellaphora stroemii complex (Bacillariophyceae). - Fottea 9: 243-256.

Germain, H. (1935): Flore diatomique des caves du Musée Saint-Jean, à Angers. Bull. Soc. Bot. France 82: $43-47$.

Germain, H. (1981): Flore des Diatomées: diatomophycées eaux douces et saumâtres du massif armoricain et des contrées voisines d'Europe occidentale. - 444 pp., Ed. Boubée, Paris.

Germain, H. (1982): Navicula joubaudii nov. nom. (Bacilla- 
riophyceae). - Crypt. Algol. 3: 33-36.

Granetti, B. (1968a): Studio comparativo della struttura e del ciclo biologico di due diatomee di acqua dolce: Navicula minima Grun. e Navicula seminulum Grun. I. Struttura e cicle biologico di Navicula minima Grun. coltivata in vitro. - Giorn. Bot. Ital. 102: 133158.

Granetti, B. (1968b): Studio comparativo della struttura e del ciclo biologico di due diatomee di acqua dolce: Navicula minima Grun. e Navicula seminulum Grun. II. Struttura e cicle biologico di Navicula seminulum Grun. coltivata in vitro. - Giorn. Bot. Ital. 102: 167-185.

Granetti, B. (1968c): Studio comparativo della struttura e del ciclo biologico di due diatomee di acqua dolce: Navicula minima Grun. e Navicula seminulum Grun. III. Esame dei caratteri di Navicula minima Grun. e di Navicula seminulum Grun. - Giorn. Bot. Ital. 102: 195-205.

Granetti, B. (1968d): Revisione critica di Navicula nigrii, Navicula casertana, Pinnularia passerinii, Stauroneis verbania e Synedra juliana De Notaris. - Giorn. Bot. Ital. 102: 427-437.

GRuNow, A. (1860): Ueber neue oder ungenügend gekannte Algen. Erste Folge, Diatomeen, Familie Naviculaceen. - Verh. zool.-bot. Ges. Wien 10: 503-582.

Hammer, O.; Harper, D.A.T. \& Ryan, P.D. (2001): PAST: Paleontological statistics software package for education and data analysis. - Palaeontol. Electronica 4: $1-9$.

Hofmann, G.; Werum, M. \& Lange-Bertalot, H. (2011): Diatomeen im Süßwasser-Benthos von Mitteleuropa. Bestimmungsflora Kieselalgen für die ökologische Praxis. Über 700 der häufigsten Arten und ihre Ökologie. - 908 pp., A.R.G. Gantner, Ruggell, Liechtenstein.

Hotelling, H. (1951): A generalized T test and measure of multivariate dispersion. - In: Newman, J. (ed.): Proceedings of the second Berkeley Symposium on Mathematical Statistics and Probability. - pp. 23-42, University of California Press, Berkeley.

Hustedt, F. (1930): Bacillariophyta (Diatomeae). - In: PASCHER, A. (ed.): Die Süsswasser-Flora Mitteleuropas. Heft 10. - 466 pp. Gustav Fischer, Jena.

Hustedt, F. (1931): Diatomeen aus dem Feforvatn in Norwegen. - Arch. Hydrobiol. 22: 537-545.

Hustedt, F. (1934a): In: Schmidt, A. et al. (eds): Atlas der Diatomaceen-kunde. Leipzig. O.R. Reisland Series VIII (Heft 99-100). - pl. 393-400.

Hustedt, F. (1934b): Die Diatomeenflora von Poggenpohls Moor bei Dötlingen in Oldenburg. - Abhandl. Vortr. Brem. Wiss. Ges. 8: 362-403.

Hustedt, F. (1937): Systematische und ökologische Untersuchungen über die Diatomeen-Flora von Java, Bali und Sumatra nach dem Material der Deutschen Limnologischen Sunda-Expedition. "Tropische Binnengewässer, Band VII”. - Arch. Hydrobiol., Suppl. 15: 187-295.

Hustedt, F. (1942): Diatomeen aus der Umgebung von Abisko in Schwedisch-Lappland. - Arch. Hydrobiol. 39: $87-174$.

Hustedt, F. (1943): Die Diatomeenflora einiger Hochgebirgsseen der Landschaft Davos in den Schweizer Alpen. - Int. Rev. ges. Hydrobiol. Hydrogr. 43: 124-197.
Hustedt, F. (1945): Diatomeen aus Seen und Quellgebieten der Balkan-Halbinsel. - Arch. Hydrobiol. 40: 867973.

Hustedt, F. (1954): Die Diatomeenflora der Eifelmaare. Arch. Hydrobiol. 48: 451-496.

Hustedt, F. (1962): Die Kieselalgen Deutschlands, Österreichs und der Schweiz unter Berücksichtigung der übrigen Länder Europas sowie der angrenzenden Meeresgebiete. - In: Rabenhorst, L. (ed.): Kryptogamenflora von Deutschland, Österreich und der Schweiz, Teil 3. - pp. 161-348, Akademische Verlagsgesellschaft, Leipzig.

JAHN, R. \& KusBer, W.-H. (2009): A key to diatom nomenclature. - Diatom Res. 24: 101-111.

Kapetanović, T.; JaHn, R.; RedžIĆ, S. \& Carić, M. (2011): Diatoms in a poor fen of Bijambare protected landscape, Bosnia \& Herzegovina. - Nova Hedwigia 93: $125-151$.

Karayeva, N.I. \& Genkal, S.I. (1993): The diatoms of the genus Navicula Bory (Bacillariophyta) in the Volga River. - Limnologica 23: 309-321.

Kobayasi, H. \& Mayama, S. (1989): Evaluation of river water quality by diatoms. - Kor. J. Phycol. 4: 121-133.

KocioleK, J.P. (1996): Comment: Taxonomic instability and the creation of Naviculadicta Lange-Bertalot in Lange-Bertalot \& Moser, a new catch-all genus of diatoms. - Diatom Res. 11: 219-222.

Kociolek, J.P. (2004): Annotated listing of diatom types in Rabenhorst's Die Algen Europa's 1848-1882, and a consideration of their nomenclatural status. - Proc. Calif. Acad. Sci. 55: 255-299.

Kociolek, J.P.; Stepanek, J.G.; Lowe, R.L.; Johansen J.R. \& SHERwood, A.R. (2013): Molecular data show the enigmatic cave-dwelling diatom Diprora (Bacillariophyceae) to be a raphid diatom. - Eur. J. Phycol. 48: 474-484.

Kociolek, J.P.; Laslandes, B.; Bennett, D.; Thomas, E.; Brady, M. \& GraefF, C. (2014): Diatoms of the United States 1. Taxonomy, ultrastructure and descriptions of new species and other rarely reported taxa from lake sediments in the Western U.S.A. - In: Lange-Bertalot, H. \& Kociolek, P. (eds): Bibliotheca Diatomologica, vol. 61. - 188 pp., J. Cramer, Gebrüder Borntraeger, Stuttgart.

Kopalová, K.; Elster, J.; Nedbalová, L. \& Van de Vijver, B. (2009): Three new terrestrial diatom species from seepage areas on James Ross Island (Antarctic Peninsula Region). - Diatom Res. 24: 113-122.

Krammer, K. \& Lange-Bertalot, H. (1985): Naviculaceae. Neue und wenig bekannte Taxa, neue Kombinationen und Synonyme sowie Bemerkungen zu einigen Gattungen. - In: Cramer, J. (ed.): Bibliotheca Diatomologica, vol. 9. - 230 pp., J. Cramer, Gebrüder Borntraeger, Berlin \& Stuttgart.

Krammer, K. \& Lange-Bertalot, H. (1986): Bacillariophyceae. 1. Teil: Naviculaceae. - In: EtTL, H.; GärTNER, G.; Gerloff, J.; Heynig, H. \& Mollenhauer, D. (eds): Süßwasserflora von Mitteleuropa, vol. 2/1 876 pp., Gustav Fischer Verlag, Stuttgart.

Krammer, K. \& Lange-Bertalot, H. (1991): Bacillariophyceae. 4. Teil: Achnanthaceae, Kritische Ergänzungen zu Navicula (Lineolatae) und Gomphonema Gesamtliteraturverzeichnis Teil 1-4. - In: EтTL, H.; GÄRTner, G.; Gerloff, J.; Heynig, H. \& Mollenhauer, D. (eds): Süßwasserflora von Mitteleuropa, vol. 2/4 
- 437 pp., Gustav Fischer Verlag, Stuttgart.

Kulikovskiy, M.S.; Lange-Bertalot, H. \& Witkowski, A. (2010a): Diatom flora of Polistovo-Lowatski Sphagnum tract (European Russia). I. Eolimna chistiakovae sp. nov. and further transfers to the genus Eolimna Lange-Bertalot \& Schiller. - Diatom Res. 25: 77-85.

Kulikovskiy, M.S.; Lange-Bertalot, H.; WitKowski, A.; Dorofeyuk, N.I. \& Genkal, S.I. (2010b): Diatoms from Sphagnum bogs of the world I. Nur bog in northern Mongolia. - In: LANGE-Bertalot, H. \& KoCIOLEK, P. (eds): Bibliotheca Diatomologica, vol. 55 326 pp., J. Cramer, Gebrüder Borntraeger, Stuttgart.

Kulikovskiy, M.S.; Lange-Bertalot, H.; Khursevich, G.K. \& Kuznetsova, I.V. (2012): New diatom species of the genus Eolimna (Bacillariophyceae) from Lake Baikal. - Nov. Sist. Nizshikh Rastenij 46: 46-51.

Kulikovskiy, M.S.; Gusev, E.; Andreeva, S. \& AnnenKova, N. (2014): Phylogenetic position of the diatom genus Geissleria Lange-Bertalot \& Metzeltin and description of two new species from Siberian mountain lakes. - Phytotaxa 177: 249-260.

KütZING, F.T. (1844): Die Kieselschaligen. Bacillarien oder Diatomeen. - $152 \mathrm{pp}$. Nordhausen.

Lange-Bertalot, H. (1976): Eine Revision zur Taxonomie der Nitzschiae Lanceolatae Grunow. Die ,klassischen" bis 1930 beschriebenen Süßwasserarten Europas. - Nova Hedwigia 28: 253-307.

Lange-Bertalot, H. \& BoniK, K. (1976): Massenentwicklung bisher seltener und unbekannter Diatomeen als Indikator starker Abwasserbelastung in Flüssen. Algol. Studies 16: 303-332.

Lange-Bertalot, H. \& Rumrich, U. (1981): The taxonomic identity of some ecologically important small Naviculae. - In: Ross, R. (ed.): Proceedings of the Sixth Symposium on Recent and Fossil Diatoms, Budapest, September 1-5, 1980, Taxonomy-Morphology-Ecology-Biology. - pp. 135-154, Koeltz, Königstein.

Lange-Bertalot, H. \& Moser, G. (1994): Brachysira: Monographie der Gattung. Wichtige Indikator-Species für das Gewässer-Monitoring und Naviculadicta nov. gen. Ein Lösungsvorschlag zu dem Problem $\mathrm{Na}$ vicula sensu lato ohne Navicula sensu stricto. - In: Lange-Bertalot, H. (ed.): Bibliotheca Diatomologica, vol. 29. - 212 pp. J. Cramer, Gebrüder Borntraeger, Stuttgart.

Lange-Bertalot, H. \& Ulrich, S. (2014): Contributions to the taxonomy of needle-shaped Fragilaria and Ulnaria. - Lauterbornia 78: 1-73.

Lange-Bertalot, H.; Bąk, M.; Witkowski, A. \& TagliavenTI, N. (2011): Eunotia and some related genera. - In: Lange-Bertalot, H. (ed.): Diatoms of Europe. Diatoms of the European Inland Waters and Comparable Habitats, vol. 6. - 747 pp. A.R.G. Gantner Verlag, Ruggell, Liechtenstein.

Lange-Bertalot, H.; Cavacini, P.; Tagliaventi, N. \& AlfiniTO, S. (2003): Diatoms of Sardinia. Rare and 76 new species in rock pools and other ephemeral waters. In: Lange-Bertalot, H. (ed.): Iconographia Diatomologica, vol. 12. - 438 pp. A.R.G. Gantner Verlag, Ruggell, Liechtenstein.

Lavoie, I.; Campeau, S.; Grenier, M. \& Dillon, P.J. (2006): A diatom-based for the biological assessment of eastern Canadian rivers: an application of correspond- ence analysis (CA). - Can. J. Fish. Aquat. Sci. 8: 1793-1811.

Lavoie, I.; Hamilton, P.B.; Campeau, S.; Grenier, M. \& DilLON, P.J. (2008): Guide d'identification des diatomées des rivières de l'Est du Canada. - 241 pp. Presses de l'Université du Québec, Québec.

Levkov, Z. (2009): Amphora sensu lato. - In: LANGE-BERtalot, H. (ed.): Diatoms of Europe. Diatoms of the European Inland Waters and Comparable Habitats, vol. 5. - 916 pp. A.R.G. Gantner Verlag, Ruggell, Liechtenstein.

Levkov, Z.; Metzeltin, D. \& Pavlov, A. (2013): Luticola and Luticolopsis. - In: LANGe-Bertalot, H. (ed.): Diatoms of Europe. Diatoms of the European Inland Waters and Comparable Habitats, vol. 7. - 697 pp. Koeltz, Königstein.

Lobo, E.A. \& Kobayasi, H. (1990): Shannon's diversity index applied to some freshwater diatom assemblages in the Sakawa River System (Kanagawa Pref., Japan) and its use as an indicator of water quality. - Jap. J. Phycol. 38: 229-243.

Lowe, R.L.; Kociolek, P.; Johansen, J.R.; Van De Vijver, B.; Lange-Bertalot, H. \& Kopalová, K. (2014): Humidophila gen. nov., a new genus for a group of diatoms (Bacillariophyta) formerly within the genus Diadesmis: species from Hawai'i, including one new species. - Diatom Res. 29: 351-360.

Maier, M. \& RotT, E. (1990): The effect of local waste-water inflows on the structure of diatom assemblages in fast-flowing streams. - In: SimOLA, H. (ed.): Proceedings of the $10^{\text {th }}$ International Diatom Symposium, Joensuu, Finland, August 28-September 2, 1988. pp. 553-561, Koeltz, Königstein.

Mann, D.G. (1989): The diatom genus Sellaphora: separation from Navicula. - Br. Phycol. J. 24: 1-20.

Mann, D.G. \& Evans, K.M. (2007): Molecular genetics and the neglected art of diatomics. In: BRodIE, J. \& LEWIS, J. (eds): Unravelling the algae: the past, present, and future of algal systematics. The Systematics Association Special Volume Series, 75. - pp. 231-265. CRC Press, Taylor \& Francis Group, Boca Raton.

Mann, D.G. \& Stickle, A.J. (2009): Cytological characteristics of the Sellaphoraceae. - Acta Bot. Croat. 68: 239-250.

Mann, D.G. \& Vanormelingen, P. (2013): An inordinate fondness? The number, distributions, and origins of diatom species. - J. Euk. Microbiol. 60: 414-420.

Mann, D.G.; Chepurnov, V.A. \& Droop, S.J.M. (1999): Sexuality, incompatibility, size variation, and preferential polyandry in natural populations and clones of Sellaphora pupula (Bacillariophyceae). - J. Phycol. 35: $152-170$.

Mann, D.G.; McDonald, S.M.; Bayer, M.M.; Droop, S.J.M.; Chepurnov, V.A.; Loke, R.E.; Ciobanu, A. \& du Buf, J.M.H. (2004): Morphometric analysis, ultrastructure and mating data provide evidence for five new species of Sellaphora (Bacillariophyceae). - Phycologia 43: 459-482.

Mann, D.G.; Thomas, S.J. \& Evans, K.M. (2008): Revision of the diatom genus Sellaphora: a first account of the larger species in the British Isles. - Fottea 8: 15-78.

Mann, D.G.; Evans, K.M.; Chepurnov, V.A. \& Nagai, S. (2009): Morphology and formal description of Sellaphora bisexualis, sp. nov. (Bacillariophyta). - Fottea 9: 199-209. 
Mann, D.G.; Poulí̌̌KovÁ, A.; SAto, S. \& Evans, K.M. (2011): Scaly incunabula, auxospore development, and girdle polymorphism in Sellaphora marvanii sp. nov. (Bacillariophyceae). - J. Phycol. 47: 1368-1378.

Mann, D.G.; Sato, S.; Rovira, L. \& Trobajo, R. (2013): Paedogamy and auxosporulation in Nitzschia sect. Lanceolatae (Bacillariophyta). - Phycologia 52: 204-220.

Mayama, S.; IdeI, M.; Osada, K. \& Nagumo, T. (2002): Nomenclatural changes for 20 diatom taxa occurring in Japan. - Diatom 18: 89-91.

McNeill, J.; Barrie, F.R.; Buck, W.R.; Demoulin, V.; GreuTer, W.; Hawksworth, D.L.; HerendeEn, P.S.; KnapP, S.; Marhold, K.; Prado, J.; Prud'homme Van ReiNe, W.F.; Smith, G.F. \& Wiersema, J.H. (2012): International Code of Nomenclature for algae, fungi, and plants (Melbourne Code. Adopted by the Eighteenth International Botanical Congress Melbourne, Australia, July 2011). - 154 pp. Regnum Vegetabile. Koeltz Scientific Books, Königstein.

MereschKowsky, C. (1902): On Sellaphora, a new genus of diatoms. - Ann. Mag. Nat. Hist., series 7, 9: 185-195.

Metzeltin, D. \& Lange-Bertalot, H. (1998): Tropical diatoms of South America I: About 700 predominantly rarely known or new taxa representative of the Neotropical flora. - In: Lange-Bertalot, H. (ed.): Iconographia Diatomologica, vol. 5. - 695 pp. Koeltz Scientific Books, Königstein.

Metzeltin, D. \& Lange-Bertalot, H. (2002): Diatoms from the "Island Continent". Madagascar. - In: LANGEBertalot, H. (ed.): Iconographia Diatomologica, vol. 11. - 286 pp. Koeltz Scientific Books, Königstein.

Metzeltin, D. \& Lange-Bertalot, H. (2007): Tropical diatoms of South America II: Special remarks on biogeography disjunction. - In: LANGE-BERTALOT, H. (ed.): Iconographia Diatomologica, vol. 18. - 877 pp. A.R.G. Gantner Verlag, Ruggell, Liechtenstein.

Metzeltin, D.; Lange-Bertalot, H. \& García-Rodríguez, F. (2005): Diatoms of Uruguay. Compared with other taxa from South America and elsewhere. - In: LANGE-Bertalot, H. (ed.): Iconographia Diatomologica, vol. 15. - 736 pp. A.R.G. Gantner Verlag, Ruggell, Liechtenstein.

Moisset, S.; Kim Tiam, S.; Feurtet-Mazel, A.; Morin, S.; Delmas, F.; Mazzella, N. \& Gonzalez, P. (2015): Genetic and physiological responses of three freshwater diatoms to realistic diuron exposures. - Env. Sci. Poll. Res. 22: 4046-4055.

Monnier, O.; Lange-Bertalot, H. \& Bertrand, J. (2003): La flore des diatomées d'un aquarium d'eau douce tropicale I. Observations taxinomiques. - Bull. Soc. Sci. Nat. Ouest France, $2^{\text {ème }}$ supplément Hors Série: 125-165.

Morales, E.A. \& Manoylov, K.M. (2009): Mayamaea cahabaensis sp. nov. (Bacillariophyceae), a new freshwater diatom from streams in the southern United States. - Proc. Acad. Nat. Sci. Philad. 158: 49-59.

Morin, S.; Corcoll, N.; Bonet, B.; Tlili, A. \& Guasch, H. (2014): Diatom responses to zinc contamination along a Mediterranean river. - Plant Ecol. Evol. 147: 325-332.

Moser, G.; Lange-Bertalot, H. \& Metzeltin, D. (1998): Insel der Endemiten Geobotanisches Phänomen Neukaledonien (Island of endemics New Caledonia - a geobotanical phenomenon). - In: LANGE-BerTALOT,
H. \& Kociolek, P. (eds): Bibliotheca Diatomologica, vol. 38. - 464 pp., J. Cramer, Gebrüder Borntraeger, Berlin \& Stuttgart.

Novis, P.M.; Braidwood, J. \& Kilroy, C. (2012): Small diatoms (Bacillariophyta) in cultures from the Styx River, New Zealand, including descriptions of three new species. - Phytotaxa 64: 11-45.

PAtrick, R.M. (1959): New species and nomenclatural changes in the genus Navicula (Bacillariophyceae). Proc. Acad. Nat. Sci. Philad. 111: 91-108.

Patrick, R. \& Reimer, C.W. (1975): The Diatoms of the United States, vol. 2. - Monogr. Acad. Nat. Sci. Philad. 13: $1-213$.

Petersen, J.B. (1924): Freshwater algae from the north coast of Greenland collected by the late Dr. Th. Wulff. - In: Den II Thule Expedition til Grønlands Nordskyst (1916-18) Nr. 13. København. Bianco Lunos Bogtrykkeri. - Meddelelser om Grønland 64: 307319.

Potapova, M. (2013): The types of 22 Navicula (Bacillariophyta) species described by Ruth Patrick. - Proc. Acad. Nat. Sci. Philad. 162: 1-23.

Potapova, M.G. \& Ponader, K.C. (2008): New species and combinations in the diatom genus Sellaphora (Sellaphoraceae) from southeastern United States. - Har. Pap. Bot. 13: 171-181.

PoulíčKovÁ, A.; Sato, S.; Evans, K.M.; Chepurnov, V.A. \& MANN, D.G. (2015): Repeated evolution of uniparental reproduction in Sellaphora (Bacillariophyceae). Eur. J. Phycol. 50: 62-79.

R Core Development Team (2014): R: A language and environment for statistical computing. R Foundation for Statistical Computing, Vienna, Austria. ISBN 3-900051-07-0 URL http://www.R-project.org/

RABEnhorst, L. (1853): Die Süsswasser-Diatomaceen (Bacillarien) für Freunde der Mikroskopie. - 72 pp., Eduard Kummer, Leipzig.

RABENHORST, L. (1864): Flora Europaea Algarum aquae dulcis et submarinae. Sectio I. Algas diatomaceas complectens, cum figuris generum omnium xylographice impressis. - 359 pp. Lipsiae apud Eduardum Kummerum, Leipzig (Lipsiae).

RABENHORST, L. (1872): Die Algen Europa's (Fortsetzung der Algen Sachsens, resp. Mitteleuropa's). Decas 227228. Dresden.

ReICHARDT, E. (1982): Die Diatomeenflora der „Steinernen Rinnen“ in Mittelfranken. - Ber. Bayer. Bot. Ges. 53: 97-112.

Reichardt, E. (1983): Diatomeen aus dem Lough Neagh. Nova Hedwigia 38: 401-420.

Reichardt, E. (1984): Die Diatomeen der Altmühl (Beiträge zur Diatomeenflora der Altmühl 2). - In: Cramer, J. (ed.): Bibliotheca Diatomologica, vol. 6. - 169 pp., J. Cramer, Vaduz.

Reichardt, E. (1994): Zur Diatomeenflora (Bacillariophyceae) tuffabscheidender Quellen und Bache im Südlichen Frankenjura. - Ber. Bayer. Bot. Ges. 64: 119-133.

REICHARDT, E. (2004): Eine bemerkenswerte Diatomeenassoziation in einem Quellehabitat im Grazer Bergland, Österreich. - In: LANGE-BERTALOT, H (ed.): Iconographia Diatomologica, vol. 13., pp. 419-479. A.R.G. Gantner Verlag, Ruggell, Liechtenstein.

Reichardt, E. (2006): Bemerkenswerte Diatomeenfunde aus Bayern V - Neue und seltene Arten aus der Schwar- 
zachklamm. - Ber. Bayer. Bot. Ges. 76: 41-51.

ReIchardt, E. (2011): Beitrag zur Diatomeenflora (Bacillariophyceae) des Paterzeller Eibenwaldes. - Ber. Bayer. Bot. Ges. 81: 5-28.

REICHARDT, E. (2015a): The identity of Gomphonema clavatum Ehrenberg (Bacillariophyceae) and typification of five species of the genus Gomphonema described by C.G. Ehrenberg. - Diatom Res. 30: 141-149.

Reichardt, E. (2015b): Gomphonema gracile Ehrenberg sensu stricto et sensu auct. (Bacillariophyceae): A taxonomic revision. - Nova Hedwigia: doi: 10.1127/ nova hedwigia/2015/0275

Riaux-Gobin, C.; Compère, P.; Coste, M.; Straub, F. \& ТАХвÖск, L. (2014): Cocconeis napukensis sp. nov. (Bacillariophyceae) from Napuka Atoll (South Pacific) and lectotypification of Cocconeis subtilissima Meister. - Fottea 14: 209-224.

Rimet, F.; Kermarrec, L.; Bouchez, A.; Hoffmann, L.; EcTOR, L. \& MedLIN, L.K. (2011): Molecular phylogeny of the family Bacillariaceae based on 18S rDNA sequences: focus on freshwater Nitzschia of the section Lanceolatae. - Diatom Res. 26: 273-291.

Rimet, F.; Trobajo, R.; Mann, D.G.; Kermarrec, L.; Franc, A.; Domaizon, I. \& Bouchez, A. (2014): When is sampling complete? The effects of geographical range and marker choice on perceived diversity in Nitzschia palea (Bacillariophyta). - Protist 165: 245-259.

Romero, O.E. \& JAHN, R. (2013): Typification of Cocconeis lineata and Cocconeis euglypta (Bacillariophyta). Diatom Res. 28: 175-184.

Ross, R. (1947): Freshwater Diatomeae (Bacillariophyta). Bull. Natl. Mus. Can. 97: 178-233.

Rotт, E. (1995): Diatoms of the Grand River, Ontario, Canada restudied after 25 years. - Limnologica 25: 165-192.

Round, F.E. \& Mann, D.G. (1996): Review: Brachysira. Monographie der Gattung. H. Lange-Bertalot \& G. Moser (1994). 212 pp. J. Cramer, Berlin \& Stuttgart. - Diatom Res. 10: 359-361.

Round, F.E.; Crawford, R.M. \& Mann, D.G. (1990): The diatoms. Biology and morphology of the genera. 747 pp., Cambridge University Press, Cambridge.

SAYRE, G. (1969): Cryptogamae exsiccatae: an annotated bibliography of published exsiccatae of Algae, Lichenes, Hepaticae, and Musci. - Mem. N.Y. Bot. Gard. 19: 1-179.

Schiller, W. \& Lange-Bertalot, H. (1997): Eolimna martinii n.gen., n.sp. (Bacillariophyceae) aus dem UnterOligozän von Sieblos/Rhon im Vergleich mit ähnlichen rezenten Taxa. - Paläont. Z. 71: 163-172.

Schimanski, H. (1973): Beitrag zur Diatomeenflora von Erlangen. - Nova Hedwigia 24: 237-335.

Schmidt, R.; Mäusbacher, R. \& Müller, J. (1990): Holocene diatom flora and stratigraphy from sediment cores of two Antarctic lakes (King George Island). - J. Paleontol. 3: 55-74.

Schoeman, F.R. \& Archibald, R.E.M. (1977): The Diatom Flora of Southern Africa. ${ }^{\circ}$ 3. - 61 pp., National Institute for Water Research, Pretoria.

Schoeman, F.R.; Archibald, R.E.M. \& Barlow, D.J. (1976): Structural observations and notes on the freshwater diatom Navicula pelliculosa (Brébisson ex Kützing) Hilse. - Br. Phycol. J. 11: 251-263.

SCHÖNFELDT, H. von (1907): Diatomaceae Germaniae: die deutschen Diatomeen des Süsswassers und des Brackwassers. - 263 pp., pl. 1-19. W. Junk, Berlin.

Silva, W.J.; Jahn, R.; Ludwig, T.A.V. \& Menezes, A. (2013): Typification of seven species of Encyonema and characterization of Encyonema leibleinii comb. nov. - Fottea 13: 119-132.

Silva-Benavides, A.-M. (1996): The epilithic diatom flora of a pristine and a polluted river in Costa Rica, Central America. - Diatom Res. 11: 105-142.

Simonsen, R. (1987): Atlas and catalogue of the diatom types of Friedrich Hustedt. - vol. 1: 525 pp., vol. 2: pls 1-395, vol. 3: pls 396-772, J. Cramer, Gebrüder Borntraeger, Berlin \& Stuttgart.

Siver, P.A. \& Hamilton, P.B. (2011): The freshwater flora of waterbodies on the Atlantic Coastal Plain. - In: LANGE-Bertalot, H. (ed.): Iconographia Diatomologica, vol. 22. - 916 pp. A.R.G. Gantner Verlag, Ruggell, Liechtenstein.

Sмiтн, W. (1853): Synopsis of British Diatomaceae. - vol. 1, 89 pp., pl. 1-31. John Van Voorst, London.

Stanek-Tarkowska, J.; Noga, T.; Pajączek, A.; \& Peszek, $€$. (2013): The occurrence of Sellaphora nana (Hust.) Lange-Bert. Cavacini, Tagliaventi \& Alfinito, Stauroneis borrichii (J.B. Petersen) J.W.G. Lund, $S$. parathermicola Lange-Bert. and S. thermicola (J.B. Petersen) J.W.G. Lund on agricultural soils. - Algol. Studies 142: 109-120.

Stoermer, E.F.; Kreis, R.G. \& Andresen, N.A. (1999): Checklist of diatoms from the Laurentian Great Lakes. II. - J. Great Lakes Res. 25: 515-566.

Taylor, J.C. \& Lange-Bertalot, H. (2006): Eolimna archibaldii spec. nov. and Navigiolum adamantiforme comb. nov. (Bacillariophyceae): two possibly endemic elements of the South African diatom flora tolerant to surface water pollution. - Afr. J. Aquat. Sci. 31: 175-183.

Taylor, J.C.; Cocquyt, C.; Karthick, B. \& Van de Vijver, B. (2014): Analysis of the type of Achnanthes exigua Grunow (Bacillariophyta) with the description of a new Antarctic diatom species. - Fottea 14: 43-51.

ThIERs, B. et al. [CONTINUOUSLY UPDATED]. Index Herbariorum: A global directory of public herbaria and associated staff (http://sweetgum.nybg.org/ih/), 15 October 2014. New York Botanical Garden's Virtual Herbarium, Bronx, New York.

Trobajo, R.; Rovira, L.; Ector, L.; Wetzel, C.E.; Kelly, M. \& MAnN, D.G. (2013): Morphology and identity of some ecologically important small Nitzschia species. - Diatom Res. 28: 37-59.

Tuji, A. \& Williams, D.M. (2013): Examination of types in the Fragilaria vaucheriae-intermedia species complex. - Bull. Natl Mus. Nat. Sci., Series B (Botany) 39: 1-9.

VAn de ViJver, B. \& Cox, E.J. (2013): New and interesting small-celled naviculoid diatoms (Bacillariophyceae) from a lava tube cave on Île Amsterdam (TAAF, Southern Indian Ocean). - Cryptog. Algol. 34: 3747.

VAN DE ViJVer, B. \& Cox, E.J. (2015): Fallacia emmae sp. nov., (Bacillariophyceae) a new soil-inhabiting diatom species from the sub-Antarctic Region. - Cryptog. Algol. 36

Van de Vijver, B.; Frenot, Y. \& Beyens L. (2002): Freshwater diatoms from Île de la Possession (Crozet Archipelago, Subantarctica). - In: Lange-Bertalot, H. \& 
Kociolek, P. (eds): Bibliotheca Diatomologica, vol. 46. - 412 pp., J. Cramer, Gebrüder Borntraeger, Berlin \& Stuttgart.

Van de Vijver, B.; Kopalová, K.; Zidarova, R. \& Cox, E.J. (2013): New and interesting small-celled naviculoid diatoms (Bacillariophyta) from the Marine Antarctic Region. - Nova Hedwigia 97: 189-208.

Van de Vijver, B.; Kopalová, K.; Zidarova, R. \& Levkov, Z. (2014): Revision of the genus Halamphora (Bacillariophyta) in the Antarctic Region. - Plant Ecol. Evol. 147: 374-391.

VAn de ViJver, B.; Ector, L.; Beltrami, M.E.; de HaAn, M.; Falasco, E.; Hlúbiková, D.; Jarlman, A.; Kelly, M.; Novais, M.H. \& WoJTAL, A.Z. (2011): A critical analysis of the type material of Achnanthidium lineare W.Sm. (Bacillariophyceae). - Algological Studies 136/137: 167-191.

Van Heurck, H. (1880): Synopsis des Diatomées de Belgique. Atlas. - plates 1-30., J. Ducaju \& Cie, Anvers.

Van Heurck, H. (1885): Synopsis des Diatomées de Belgique. Text. - 235 pp., Martin Brouwers \& Co, Anvers.

Vanormelingen, P.; Evans, K.M.; Chepurnov, V.A.; VyverMAN, W. \& MANN, D.G. (2013). Molecular species discovery in the diatom Sellaphora and its congruence with mating trials. - Fottea 13: 133-148.

Wasell, A. \& HÅkAnsson, H. (1992): Diatom stratigraphy in a lake on Horseshoe Island, Antarctica: a marinebrackish-fresh water transition with comments on the systematics and ecology of the most common diatoms. - Diatom Res. 7: 157-194.

Weber, C.I. \& McFarland, B.H. (1981): Effects of copper on the periphyton of a small calcareous stream. Ecological Assessments of Effluent Impacts on Communities of Indigenous Aquatic Organisms. ASTM STP 730: 101-131.
Werum, M. \& Lange-Bertalot, H. (2004): Diatoms in springs from Central Europe and elsewhere under the influence of hydrogeology and anthropogenic impacts. - In: LANGE-BERTALOT, H. (ed.): Iconographia Diatomologica, vol. 13. - pp. 3-417. A.R.G. Gantner Verlag, Ruggell, Liechtenstein.

Wetzel, C.E.; Martínez-Carreras, N.; Huúbiková, D.; Hoffmann, L.; Pfister, L. \& Ector, L. (2013): New combinations and type analysis of Chamaepinnularia species (Bacillariophyceae) from aerial habitats. - Cryptogam. Algol. 34: 149-168.

ŻELEZnA-WIECZOREK, J. (2011): Diatom flora in springs of Łódź Hills (Central Poland). Biodiversity, taxonomy, and temporal changes of epipsammic diatom assemblages in springs affected by human impact. - In: Witkowski, A. (ed.): Diatom Monographs, vol. 13. - 419 pp., A.R.G. Gantner Verlag, Ruggell, Liechtenstein.

Zgrundo, A.; Lemke, P.; Pniewski, F.; Cox, E.J. \& Latala, A. (2013): Morphological and molecular phylogenetic studies on Fistulifera saprophila. - Diatom Res. 28: 431-443.

Zimmermann, J.; Abarca, N.; EnKe, N.; Skibbe, O.; Kusber, W.-H. \& JAHN, R. (2014): Taxonomic reference libraries for environmental barcoding: a best practice example from diatom research. - PLoS One 9: e108793.

Zimmermann, J.; Glöckner, G.; Jahn, R.; EnKe, N. \& GemeINHOLZER, B. (2015): Metabarcoding vs. morphological identification to assess diatom diversity in environmental studies. - Mol. Ecol. Res. 15: 526-542.

(C) Czech Phycological Society (2015)

Received April 23, 2015

Accepted June 8, 2015 